\title{
Vandrelærer i en urolig tid
}

\section{Træk fra Gustav Lindstrøms virke i Sydslesvig fra 1920'erne til efterkrigstiden}

\section{Af Anders Ture Lindstrøm}

Denne artikel er nok et person- og slægtshistorisk bidrag, historie med supplerende erindringsskitser. Materialet er stykket sammen af min fars spredte og ikke særligt systematiske dagbogsnotitser, foredragsoplæg, små artikler m.v., således at man i hvert fald i grove træk kan følge hans færd som vandrelærer indtil 1945, da vilkårene for dansk arbejde syd for grænsen ændredes radikalt. Derefter følger en skildring af de hektiske år, hvor det danske skolevæesen udviklede sig eksplosivt, samt af perioden 1947-1961, hvor mine forældre havde en sprog- og ungdomsskole i tilknytning til det danske forsamlingshus i Ladelund, hvorfra spredt arkivmateriale eksisterer.

En særlig rolle spiller en række soldaterbreve, gennemgående skrevet af min fars tidligere elever. En række faldt, og det slog hårdt $\mathrm{i}$ de spæde danske samfund, min far forvandt det aldrig. Dermed er også antydet, at det har været meningen at skitsere træk af danskhedens udvikling i Sydtønder amt (nu den nordligste del af Kreis Nordfriesland). Min far undlod, bl.a. for at undgå at såre eller støde for hårdt, at skrive egentlige erindringer. Denne skildring vil alligevel gå en anelse videre end den traditionelle officielle historieskrivning og lejlighedsvis kalde en spade en spade.

Endelig har det været meningen at sørge for, at det danske mindretals skiftende vilkår efter 1920 bliver kædet sammen med den almindelige slesvigholstenske og tyske udvikling.

Med mindre andet udtrykkeligt angives $i$ noter og henvisninger, er fortolkninger og vurderinger naturligvis mine egne.

Min far, Gustav Lindstrøm, blev født den 21. marts 1896 i Kirke Eskilstrup på Sjælland som søn af indvandrede svenske forældre. Han blev bortadopteret og voksede op i meget beskedne kår, men havde en god adoptivmor. Først som voksen lærte han efter et ihærdigt efterforskningsarbejde sine rigtige forældre at kende og etablerede et godt forhold til den svenske familie, hans far havde stiftet. Så samtidig med, at han gennem sin opvækst var blevet sjællænder, bevarede han et nært forhold til den svenske familie og Blekinge, så det var sidenhen ikke blot det dansk-tyske problem, der fik ham til at betone de stærke nordiske bånd. 
Han var meget kvik; men der var ikke råd til megen uddannelse. Han måtte tidligt ud at tjene $\mathrm{i}$ landbruget. Men appetit på kundskaber havde han fået. Den lille landsbyskole på Sjælland var ikke det værste, man kunne komme ud for, en inspirerende landsbylærer gjorde meget for de vågne.

I 1917 lykkedes det ham at få et højskoleophold. Det blev på Frederiksborg højskole og fik, som senere ophold på Askov og Statens Lærerhøjskole, en voldsom indflydelse på hans personlige udvikling. Uden for landets grænser rasede verdenskrigen. Danmark kunne holde sig udenfor, men måtte opretholde et større beredskab, den såkaldte sikringsstyrke. Også de neutrale landes ungdom prægedes af tidens tankegods, bl.a. af afsky for krig og militarisme, der var megen sympati for pacifismen som holdning.

Som tusinder af andre unge mænd måtte han finde sig $i$ at aftjene sin værnepligt $\mathrm{i}$ sikringsstyrken, der som årene gik, blev mere og mere urolig og demoraliseret.

Indkaldelsen kom sent i 1917, og da var sikringsstyrkens moral blevet lettere flosset. Rekruttiden var hård, det militære liv var en besk oplevelse efter det muntre højskoleliv; men tiden i sikringsstyrken gav varige minder $\mathrm{i}$ form af anekdoter om plageånder blandt officerer og underofficerer. Sikringsstyrken betød også kammeratskab og venskaber, således kom han til at møde den unge historiker og senere forstander på Rødding højskole Hans Lund, der underviste soldater i Grevelejren. Det blev begyndelsen til et livslangt venskab.

Sikringsstyrkens mandskab var en broget flok. Der var solide landmænd såvel som flabede københavnere fra Vesterbro. Den brogede verden prægede også soldatersproget, der var af meget krydret karakter. Min far, der var meget optaget af at gøre sproglige iagttagelser, benyttede tiden $i$ Grevelejren til at nedfælde nogle af soldaterkammeraternes mere fantasirige udtryk, ikke mindst skældsord, øgenavne og slangudtryk. Tillige var han aktiv $i$ oplysningsarbejdet for soldaterne og læste bl.a. op på soldaterhjemmet. Bjørnstjerne Bjørnson var fast bestanddel af dette repertoire, og det førte helt naturligt til øgenavne som »Synnøve Solbakken« og »Reserve-Jesus«.

Soldaterne blev undertiden stærkt chikaneret, især af underofficererne. Efterhånden, som tiden gik, blev de indkaldte imidlertid frækkere og frækkere. En ubehagelig og kolerisk underofficer blev på det nærmeste røgforgiftet, da en glasplade blev placeret over kakkelovnsrøret, da han lå og sov i et underjordisk anlæg. Straffemarcher og straffeeksercits blev saboteret. De forhærdede syndere, der skulle straffes for opsætsig- 
hed, udførte ganske vist altid de ordrer, der blev givet, men i et så gribende langsomt tempo, at befalingsmændene var ved at blive drevet til vanvid. En enkelt straffemarch efterlod særlig muntre minder. Da soldaterne passerede en mindre sjællandsk by, afsang de hele vejen en sang, hvis tekst $i$ al sin gribende korthed lyder:»Grisen faldt og brakked låret, grisen faldt og brak sit lår.«

Maden i de militære forlægninger var af stærkt svingende kvalitet, god var den sjældent, og den gav ofte anledning til bataljer med forplejningstjenesten, der kunne svindle med den. Engang stod 300 mand og hujede uden for kostforplejningen, indtil et nyt og bedre måltid blev serveret. ${ }^{1}$

I slutningen af sin soldatertid kom far til at gøre tjeneste ved rekylgeværerne, model Madsen, også kaldet Jomfru Madsen. Jomfru Madsen var tung at danse med. Mens store influenzaepidemier hærgede i efteråret 1918, lærte han at bakse med det tunge monstrum. Efter rekylgeværuddannelsen kom han i begyndelsen af november 1918 tilbage til Grevelejren. "Efter mange omskiftelser er jeg nu atter i Greve. Er 
blevet rekylskytte. Det går rigtig godt, meget bedre end jeg havde tænkt, og nu er man da fri for al den vagt og kan hver aften gå i sin seng, og man kan have godt af atter at blive strammet op. Men kedeligt er der i Greve fraregnet skolehjemmet, hvor der blot er for overfyldt og dårligt oplyst til at læse om aftenen. ${ }^{2}$

Uddannelsen som rekylskytte blev baggrunden for en meget speciel oplevelse. Krigstidens forhold havde medført stærke sociale spændinger. Den bolchevikiske revolution i efteråret $1917 \mathrm{og}$ de revolutionære strømninger, der fulgte de følgende år $\mathrm{i}$ store dele af Europa, såvel Tyskland som Finland og de østeuropæiske lande, gjorde også i Danmark et dybt indtryk. Danmark kom en revolutionær tilstand nærmere, end det havde været siden reformationstiden. Fra 1917 havde der været syndikalisturoligheder med store sammenstød. 1918 bragte adskillige konfrontationer med havnearbejderne. Da freden kom i november 1918, blev der nye uroligheder i København. Disse førte for en kort tid til et diskret ekstraordinært militært beredskab i København. Under de store uroligheder her blev han sammen med udvalgte andre rekylskytter i hemmelighed sendt til hovedstaden som beredskabsstyrke. De københavnere, der blev anset for upålidelige, blev sorteret fra. Det var spændende dage; men han var vist lettet, da der ikke blev revolution i Danmark. Et dagbogsnotat fra de hektiske novemberdage giver en fornemmelse af den spændte situation: ${ }^{3}$

\begin{abstract}
Ermelunden den 17. november 1918
"De sidste 8 dage har varet så skiftende, at jeg ikke har haft tid til at skrive. Det varede ikke længe med at være rekylskytte, men jeg fik da oplevet det, at vi søndag nat blev kaldt op og sendt til kamp mod bolchevikkerne eller de bølledrenge, som det $\mathrm{i}$ virkeligheden kun var. $\mathrm{Nå}$, kampen blev der i virkeligheden ikke noget af, men vi blev da stadig holdt i beredskab for det tilfælde, at politiet ikke længere kunne klare skærene.

Heldigvis gjordes vores hjælp ikke nodvendig. Torsdag blev vi atter sendt til Greve, men kun for atter at flytte til Ermelunden. Nu er jeg atter stuevagt, hvad der er meget godt, men det allerbedste er dog, at jeg om kort tid har udsigt til at blive hjemsendt, og kunne jeg så bare komme til Askov efter nytår.«*
\end{abstract}

Drømmen gik i opfyldelse. Sikringsstyrken blev pacificeret og hjemsendt i hurtigt tempo. Januar 1919 blev far elev på Askov højskole. Udvidede ophold på Askov 1919-20 og 1920-21 i en voldsom national og politisk brydningstid satte deres præg. Penge var der næsten ingen af; men der var mange gode højskolekammerater. Han blev frit uddannet, uden eksamen, fik senere et supplerende ophold på Statens lærer- 
højskole. Landet syd for genforeningsgrænsen af 1920 udøvede en ubetvingelig tiltrækning på ham, og det blev til et liv i Sydslesvig. Det kan godt være lidt svært at forklare, hvorfor han havnede $i$ Mellemslesvig. Han var radikal og grundtvigianer med et stænk af indre mission, og bestemt ikke højreorienteret nationalist som mange i det grænselandsvenlige velstillede borgerskab, der støttede den spredte danskhed syd for 1920-grænsen, og det kunne lejlighedsvis give problemer med højrefløjen. Det har nok været de forskellige højskoleopholds ikke-fanatiske nationale præg, der især har startet processen. Siden blev det så de spredte danske kredse og landet, der holdt en ofte besværlig nomadetilværelse i gang med barske vilkår, få penge og under ikke altid lige taknemlige politiske vilkår.

Far kom i december 1921 første gang til Mellemslesvig, som egnene syd for grænsen nærmest svarende til 2 . zone dengang kaldtes. I Flensborg boede en samlet danskhed. Ganske anderledes stillede sagerne sig ude i de mellemslesvigske sogne. Her var befolkningen nationalt stærkt blandet. De spredte danske familier boede mellem tyske naboer og tyske embedsmænd. De lagde direkte eller indirekte tryk på folk. Den nationale splittelse gik tit langt ind $i$ den enkelte familie, som den for resten stadig gør både nord og syd for grænsen. Det kunne hænde, at mand og kone hældede til hver sin side i det nationale spørgsmål. Afstamning og minder kunne drage mod nord, tyske traditioner kunne sætte deres præg gennem skole og militærtjeneste. I et par artikler $i$ Højskolebladet 1922 har min far skildret nogle af sine første indtryk fra Mellemslesvig:

"Hvad der præger landet er stilstand. 50 års udvikling i folkelig og økonomisk henseende er til dels gået sporløst over disse egne.

Vil man studere gamle sæder og skikke, da kommer man ikke let et bedre sted end på den mellemslesvigske slette. Det er gammeldags drift, der råder $\mathrm{i}$ stald og på mark. Roer dyrker man på en måde som for 50 år siden i Danmark. Nogle steder sår man i disse år, hvor græsfrøet er dyrt, ikke noget frø i udlægsmarken, men lader naturgræsset brede sig.

Krigstiden med hele hamstresystemet har giort, at husholdningerne $\mathrm{i}$ endnu højere grad end før krigen er anlagt på selvforsyning.

Man væver, spinder, brygger og bager selv. Her kan man endnu fă lejlighed til at skue pigen eller husmoderen i dejtruget. Der er andelsmejerier; men de er usle små og har i krigstiden mistet mange medlemmer. Bor man en smule fra den alfare vej, laver man selv ved hjælp af en lille håndcentrifuge sine mejeriprodukter og sælger dem sammen med sine $\mathbf{a g}$ eller hvad man nu har til de kræmmere, der med store kurve på cykle eller til fods fra landstationerne tidlig om morgenen begiver sig ud på opkøb eller tuskhandel. 
Det er meget almindeligt, at kræmmeren har forskellige sager med fra Flensborg, som han afhænder for fedevarerne, han om eftermiddagen rejser hjem med. Så ser man dem med deres mange gode sager fylde 4. klasses-kupéerne, disse herlige indretninger, som vi i vort demokratiske Danmark ikke kender. Om man færdes ad Flensborg-Nibøl banen, skal man tage en tur på fjerde klasse. Ingen steder har man lejlighed til bedre iagttagelser. Her kommer alle mulige folk lige fra beskidte zigeunere til pæne storbønder. Rummeligheden gør, at vognen til tider kan have et meget broget indhold. Her kommer en ung frue med sin barnevogn, en opkøber med en halv gris, andre med lange kurve fulde af æg, smør og ost. Luften kan en varm sommerdag, når de 18 sidde- og de 22 ståpladser er optaget, blive noget tyk for en fremmed.

Men kan man holde det ud, er der herlige opdagelser at gøre. Her lyder høj- og plattysk, frisisk og sønderjysk $i$ en broget blanding. Hele kupeen kan skralde af latter, om en afleverer en god „Plat «-vittighed, og der kan blive røre, når et par kællinger, eller et par mænd, der har fået en grog for meget, ryger i totterne på hinanden.»

Det første indtryk, man fik af sproget i landsognene, var, at der først og fremmest blev talt tysk, man begyndte i hvert fald på tysk, men lærte man forholdene at kende, blev der faktisk talt dansk. Men man mødte ustandseligt det forhold, når man som rigsdansker begyndt at snakke med folk, at landbefolkningen ikke rigtig regnede deres dialekt, den sønderjyske dialekt blev betegnet som »kartoffeldansk « eller »platdansk «. De fleste ældre talte endnu godt sønderjysk, men blandet op med plattyske gloser.

„Det sørgeligste for os, der nødig ser det danske sprog forsvinde, er, at der, selv hvor hussproget er dansk mellem de voksne, dog de fleste steder også i udpræget dansksindede hjem tales plattysk til børnene. Mens selv den ivrigste tysksindede aldre sønderjyde $\mathrm{i}$ disse egne forstår og taler dansk og undertiden ikke kan tale ordentligt tysk, kniber det med de unge folk, fra hvilke hjem de end stammer, med at forstå og udtrykke sig på dansk. Det viser, at det er i sidste øjeblik, om det tyske sprogs fremtrængen skal standses. ${ }^{5}$

Selv sydligst i 2. zone taltes en del dansk. Min far var ikke i tvivl om, hvad der måtte gøres: "... Her er det klart, at det må være en pligt og en opgave for os at arbejde for bevarelsen af det danske sprog i disse egne.«

Med hensyn til sindelaget måtte man sige, at de mellemslesvigske landsogne var splittet og delt. Der var små faste flokke af virkelig dansksindede, små flokke tysksindede og slesvig-holstenere. "Resten er den store flok, der står vaklende tvivlende, hvor den skal vende sig 
hen. Om disse sjæle står kampen i dag. Meget er syndet af dansk ligegyldighed og misforståelse og tysk magtpolitik. Ikke underligt, at striden nu, da man fra begge sider bejler om sjælene, må blive hård. $\aleph^{6}$ Mellemslesvigerne var ikke mennesker med høje idealer, men de var heller ikke bare materialister, og opgaven var nu at bringe dem frem til klarhed over deres stilling, ved arlige midler at få dem ind i det danske folkesamfund.

»Det er tillige vort selvforsvar og med historiens og gensidighedsprincippet som grundlag vor ret som folk at få lov til at hjælpe disse mennesker af dansk rod. Der tales om, at det er de økonomiske forhold, der vender deres sindelag mod Danmark. Det er fuldstændig rigtigt, at de økonomiske goder her som alle vegne spiller en vigtig rolle, men man vinder dog ikke mange sjæle med gods og gaver, og de må hellere undværes. Tilmed har i tiden siden afstemningen det økonomiske nærmest været imod. Danmark har haft sin krisetid, der er blevet udnyttet $i$ den tyske agitation. Her har det, på de store gårde især, været højkonjunkturer med gode priser på landbrugsprodukterne, lave folkelønninger og skatter, der bliver ret små, inden de bliver opkrævet. Dette har givet mange gårdmænd et falsk billede af stillingen.

Mens da ejerne af de store gårde, fraregnet gode og hæderlige undtagelser, hovedsagelig i politisk og fagmæssig henseende har blikket vendt mod syd, er det blandt de mindre landmand og arbejderne, at interessen for Danmark er størst. Den nærliggende grænse har bragt Danmark nærmere ind på livet af dem, så de atter kan langes efter, hvad der før var dem så fjernt, hvad de, som en kone sagde, "kan se, men ikke nyde «. «?

Disse fik også gennem børn og slægtninge et mere præcist billede af danske forhold. Det var de svagere sociale lag, der mærkede skuffelsen over ikke at være komme med i dansk statsområde i 1920.

Hvad kunne man fra dansk side stille op?

"Et folk, der står som mellemslesvigerne, er det ikke så hurtigt og let at bringe kulturværdier omgående, som visse folkelag i Danmark ved de endnu ikke ret, hvad de mangler. Hos nogle er trangen så småt vakt til at leve et dansk liv. Denne trang galder det at tilfredsstille og samtidig derved at vakke den hos andre. Kendskab til dansk sprog i skrift og læsning kommer selvfølgelig som noget af det første og vigtigste. Dette er der også med små skridt taget fat på. Foredragsmøder kan her synes at være noget af det første. Der gøres dog helt andre erfaringer. Der mangler lokaler til sammenkomster. Folk er forsagte og mangler endnu mod til at møde sammen. Det er derfor foreløbig den rent personlige påvirkning mand og mand imellem, der må til. $\varkappa^{8}$

Bøger spillede endnu ikke den store rolle. Hist og her i landsbyerne stod der ganske vist bogsamlinger; men de blev næsten ikke brugt. 
"Almuesfolk er sjældent meget læsende, og de folk hos hvem bøgerne står, er $i$ reglen begyndere og kan endnu ikke give andre videre vejledning ved valg af læsning. De fleste er heller ikke stive i at læse dansk. Kun de xldste har gennem skolegang fået ordentlig øvelse i at læse modersmålet. Mange har lært sig det ved tid efter anden at kigge i Flensborg Avis. Det må beklages, når denne nu i nogle hjem af magelighed afløses af Neue Flensburger Zeitung.

Den første opgave er derfor at lære folk at læse dansk, så de derigennem kan komme i forbindelse med dansk sprog og kultur. De ældre og børnene må hjalpe sig med de sprogkursus, der de sidste år er blevet afholdt forskellige steder i Mellemslesvig. Forbavsende er det, hvor hurtigt et barn eller et ungt menneske, der taler nogenlunde dansk, kan komme efter at læse og skrive sproget forståeligt.»

I forbindelse med sprogundervisningens elementære elementer var der også lejlighed til at stifte bekendtskab med den litterære verden. Og man må huske på, at radioer endnu var en eksotisk sjældenhed, de tyndt befolkede landsogne havde ikke megen anden underholdning, end den, de selv kunne levere gennem fortællekunsten. Så H. C. Andersens eventyr, Blichers jyske noveller og folkeeventyr havde opmærksomme tilhørere.

Til det danske hørte også en kristen dansk forkyndelse, men den brede mellemslesvigske befolkning var ikke lige interesseret, i dens ideologiske forestillinger rasede foruden overtro og sekteriske begreber en vis antisemitisme. Tyske præster havde deltaget ivrigt $i$ afstemningskampen, også dette havde ført til distance mellem landskirke og befolkning. Ungdommen var præget af krigstiden, der var megen bitterhed. $\mathrm{Og}$ så var der sangen. Sangen havde hjulpet nordslesvigerne i trange tider, nu skulle den hjælpe mellemslesvigerne.

Og til den anden side af sagen, den tyske agitation. Det store slesvigholstenske bondeforbund holdt sammen på de toneangivende i sognene. Den tabte krig havde skabt et skæbnesfællesskab mellem krigsveteranerne. Skyttegravenes kammeratskab betød meget mere, end man almindeligvis troede. De tyske ungdomsbevægelser spillede også en vis rolle. Den unge vandrelærer sluttede sit mellemslesvigske udblik i 1922 med følgende:

»På et højdedrag i Mellemslesvig, hvorfra man ser langt ud over det flade land, står et forkrøblet egekrat. Det siges, at bvis der plantes læ for dette, vil det kunne rette sig. Det er et billede på egnens befolkning. Om der bliver rejst noget mere læ, vil den endnu kunne rejse sig. Men et hegn $\mathrm{i}$ disse egne vokser ikke så hurtigt. Der skal tid og tålmodighed til. ${ }^{9}$ 
Der blev også til til rejser i de nordfrisiske områder og Vestslesvig, hvis natur og historie fængede voldsomt.

Knap så meget fængede den spæde frisiske bevægelse. Min fars interesse og energi omfattede danskheden syd for grænsen, først og fremmest den, slesvigske blandingsfænomener interesserede ikke, hverken for eller efter 1945.

Allerede under de første Sydslevig-ophold (han arbejdede de første år kun en del af tiden $\mathrm{i}$ det danske skolevæsen syd for grænsen) var han en tur på Sild for at se på vilkår og interesse for det danske, og den gamle friserkultur, der var ved at uddø, betog. Det har han fortalt om bl.a. i Dansk Ungdom 21. juli 1922. Det, man ikke kunne undgå at lægge mærke til, var fattige og dårligt klædte børn. Det tyske nederlags følgevirkninger slog hårdt.

Hvordan var nu de praktiske arbejdsvilkår for den begyndende vandrelærervirksomhed? De var præget af de trykkende forhold og den stadigt meget ophidsede stemning syd for grænsen. En forældregruppe i Kær herred havde i 1921 ansøgt Dansk Skoleforening om hjælp til at få deres omkring 20 børn undervist. Da min far i december 1921 havde fået ansættelse, havde en del af forældrene fået betænkeligheder. Deltagerantallet for danskundervisningen, der foregik i en lejet stue på kroen, kom dog snart op på 14 børn, der med liv og lyst gik i gang med at lære at læse og skrive deres forsømte modersmål.

"Det voldte jo nogen forstyrrelse at have undervisning på kroen. Af og til kiggede danske fra egnen ind og hørte lidt på undervisningen. Det var kun godt. Derimod kunne kroens gaster virke generende.

Et par aftener $i$ ugen samlede jeg ligeledes de voksne til danskundervisning, sang og oplasning. Deltagerne var kromanden og krokonen og nogle unge karle og piger samt nogle mand og kvinder $\mathrm{i}$ mere moden alder.

Når det var koldt. sad vi i kroens rummelige køkken, hvor der også var en alkove. I den sov pigen, som havde et lille barn. Pigen var også med til undervisningen. Men når hun og barnet blev søvnige, trak de ind i alkoven og lukkede dørene. ${ }^{11}$

\section{Der var mange nuancer i tyvernes grænselandsdebat}

Der gik mange år, før bitterheden mellem Åbenrå- og Flensborgfolk blev dysset ned eller glemt. For en ung radikal vandrelærer var det $\mathbf{i}$ hvert fald ikke lige let at sno sig, selv når man var et rimeligt fredeligt gemyt. Kom man med en radikal avis som Politiken under armen, 
kunne man risikere at blive smidt ud $\mathrm{i}$ ellers fredelige danske hjem $\mathrm{i}$ Flensborg. Men ellers kunne man især følge nedtrykthed og underkuethed, især i danske kredse uden for Flensborg. Den spredte danskhed vestpå var langt mere sårbar over for tryk.

Et par dagbogsnotitser fra marts 1922 illustrerer dette.

Far besøgte Ketel Johannsen, der var købmand i den meget tyske by Læk: "... Han var en fremtrædende mand $i$ det danske arbejde $i$ Læk og blev derfor forfulgt af tyskerne efter afstemningen i 1920. Derfor var han og familien nu meget forsigtige, men syntes ellers at være ved godt mod.«

I Valsbøl så Lorenz Jepsen mere mørkt på stillingen. »Gik derefter hen på kirkegården og gav mig $\mathrm{i}$ snak med graveren. Han viste sig at være en god dansk mand, som kun havde gået $i$ dansk skole og var blevet konfirmeret i 1864. Han hed Jessen og udtalte sin sorg over, at de ikke var kommet til Danmark i 1920. Afstemningen skulle være kommet lige efter sammenbruddet $i$ 1918. « $^{11}$

Der blev en sjælden gang også lejlighed til at træffe den store omstridte førerskikkelse H. P. Hanssen i Åbenrå. Det var den 16. juni 1922, dagen efter genforeningsfesten. "Han var meget omgængelig og flink og fortalte mig meget værdifuldt. Han ser meget venligt på det danske Flensborg, men venter sig ikke stort af den nyslesvigske bevægelse, der, som han sagde, har ødelagt mulighederne for meget i Flensborg. Hans ord om virkeligheden som udgang for enhver politik var ord, som bed sig fast hos mig.

Hvad han sagde om førerne og lederne af danskheden i Flensborg, at de hver og én var fra Nordslesvig, virkede også stærkt overbevisende på mig. Om det danske arbejde i Flensborg kom der kun én lidt maliciøs bemærkning: de galer for højt, hver gang de har lagt et lille $æ g$... $\ll^{12}$

Både den hjemlige danske debat og de politiske opgør syd for grænsen var gennemgående præget af stor bitterhed og ideologisk skarphed. I Tyskland foregik meningsudvekslingerne de første år bl.a. med maskingevær og flammekaster. Påskekrise og afstemningsopgør gav vel ikke borgerkrigsagtige tilstande, sådan som næsten alle dele af Tyskland oplevede det fra 1918 til 1923. Men Danmark oplevede i tyverne svære sammenstød på arbejdsmarkedet, og uenigheden mellem de forskellige nationalpolitiske fløje førte til livslange personlige uoverensstemmelser og mange bizarre episoder.

For min far, der hverken var konservativ eller venstremand, og det var jo i høj grad konservative og liberale grupper, der støttede 


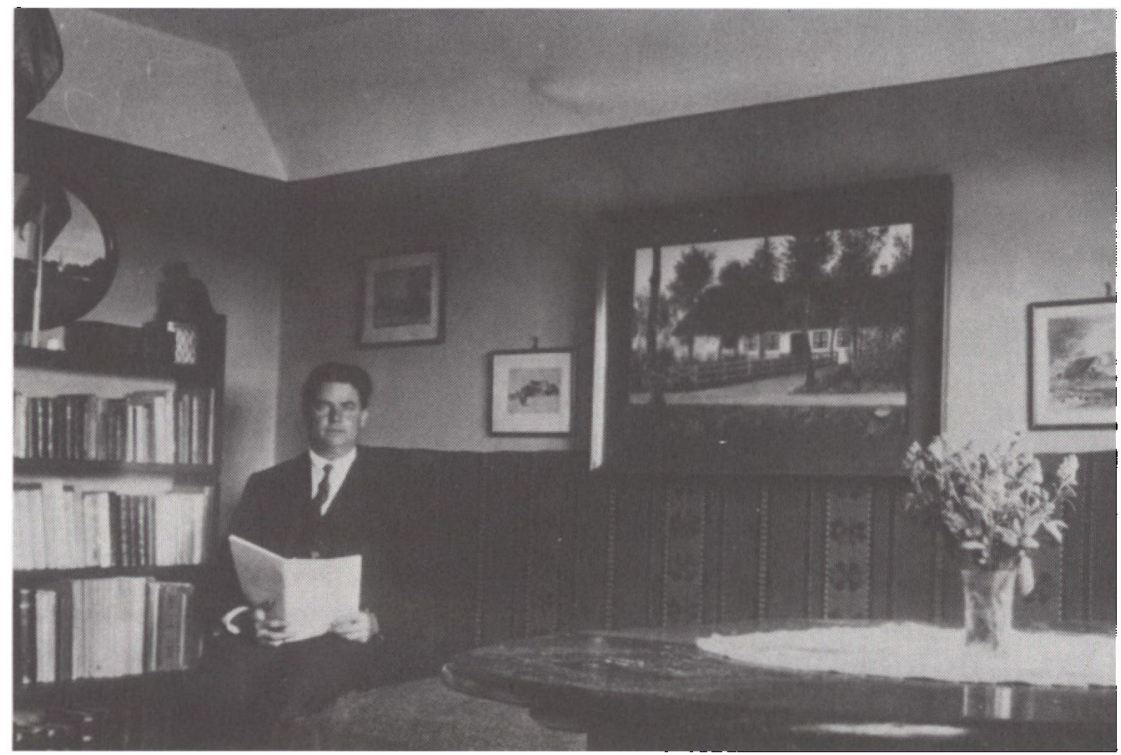

Gustav Lindstrom $i$ vandrelarerstue $i$ Ladelund, for forsamlingshuset blev bygget. (Privateje)

grænsearbejdet, blev denne problemstilling i begyndelsen lidt af en belastning, selv om han søgte at forliges med de forskellige grupper. Man kan ikke løbe fra sine forudsætninger, og han kom jo ikke ligefrem fra overklassen, men havde haft hård hud på hænderne.

"Mit forhold til det politiske griber ind og gør mit sind splittet mellem hjerte og forstand, nationale og sociale modsætninger. Kan jeg komme lykkeligt gennem den kamp? « ${ }^{13}$

Det borgerkrigshærgede Weimartysklands lokale debatklima var ofte præget af stærk aggressivitet. Det var ikke særlig praktisk at holde danske møder eller dansk undervisning på kroer eller lignende, selv om man ofte var nødt til det. Det kunne for deltagerne betyde tilbud om en god dragt prygl. Der var også kromænd, der var ængstelige for at huse dansksindede. Det førte så til, at undervisningen måtte forlægges til små private stuer, hvor der var mere hjerterum end husrum. Der blev i tidens løb undervist mange forskellige ydmyge steder. I 1922 blev det også undersøgt, om der var basis for større dansk aktivitet på Sild. Min fars konklusion var efter den interessante rejse, at danske og frisere i Vesterland, Kejtum og Munkmarsk var ængstelige og ikke turde vare med til de danske møder. I det hele taget var de danske $\mathrm{i}$ 
Mellemslesvig præget af ængstelse for prøjsiske embedsmænd og tyske naboer. Ellers var en af året 1922's store oplevelser en fælles tur for nordslesvigere og sydslesvigere til Salling, til Jeppe Åkjær på ejendommen Jenle bl.a. Det blev indledningen til mange senere ture for danske fra Sydtønder amt.

I april 1923 kunne man så indvie forsamlingsstuen »Pærs Pissel« på Østerby mark, men det kunne ikke ske uden såvel officielle som uofficielle tyske chikaner. En del af deltagerne blev generet, en dansk lærerinde revet af cyklen, så hun forstuvede en arm, skriver min far. $» O g$ da jeg en tid efter samlede børnene fra mine to vandreskoler i Jaruplund og Østerby Mark sidstnævnte sted, måtte jeg have en 5-6 danske mænd til eskorte gennem den berygtede landsby. ${ }^{14}$

\section{Den samfundsmæssige baggrund. Provinsen Slesvig-Hol- sten}

Hvordan var dette samfund? Som i det wilhelminske kejserrige var Sydslesvig og Holsten en provins i Preussen, der igen udgjorde en meget overvældende del, politisk og økonomisk, af det slagne Tyskland, der var blevet til det, vi kalder Weimarrepublikken. Regionen var efter 1920 et tildels fattigt landbrugspræget område. Der havde i forvejen været forholdsvis større industricentrer, specielt Kiel blev efter Versaillesfreden svækket og nåede først 1933-45 nye højder som marinebase og skibsværftsby. Industrialiseringen var sat ind relativt sent, endnu midt $i$ tyverne var knapt 30 procent beskæftiget $\mathrm{i}$ landbruget, der havde store strukturforskelle. På de gode jorder i den østlige del og i marsken var der store og mellemstore gårde såvel som godser, på de magre jorder $\mathrm{i}$ geesten midt $\mathrm{i}$ landet var gårdene ikke så store, forskellen til landarbejderne og daglejere tilsvarende mindre. De slesvig-holstenske landmænd havde fået oprettet mange andelsforeninger; men der var betydelige forskelle fra egn til egn med hensyn til udviklingsniveauet.

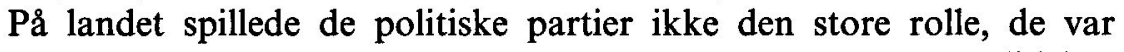
først og fremmest et byfænomen. Lokalt var det det "upolitiske« foreningsliv, landboforeninger, skytte- og veteransammenslutninger, der interesserede i det daglige. Socialdemokraterne stod forholdsvis stærkt og velorganiseret, landarbejderne stod derimod organisationsmæssigt svagt. SPD's styrke førte til stærke bestræbelser på samling af de ikke-socialistiske kræfter og til en meget giftig agitation fra højrefløjspartierne. ${ }^{15}$ Fra Hamborg kom antisemitiske strømninger. 
Antisemitismen kom til at spille en rolle som bindemiddel $\mathrm{i}$ agitationen mod demokrati og frigørelsestendenser. ${ }^{16}$

Perioden 1918-23 var en meget urolig tid i Tyskland, til tider præget af blodige opgør. Det militære nederlag og novemberrevolutionen 1918 fremkaldte skuffelse og forbitrelse i borgerlige kredse, og revolutionsfrygten styrkede de allerede eksisterende antisocialistiske strømninger, også selv om USPD, venstrefløjssocialisterne, ikke gjorde sig politisk så stærkt bemærket, og de moderate socialdemokrater lod de yderliggående spartakisters opstand slå ned. Arbejder- og soldaterråd kom kun forholdsvis kortvartigt til at spille en rolle. Politisk og administrativt skete der i Slesvig-Holsten forholdsvis beskedne ændringer efter systemskiftet. Borgerligt konservative kræfter blev ved med at spille en væsentlig rolle. De moderate SPD-folk syntes mere bekymrede for venstreorienterede end for de borgerlige, selv om det grundlæggende modsætningsforhold til de borgerlige bestod. ${ }^{17}$

Afstemningskampen om $1 . \operatorname{og} 2$. zone betød en heftig, meget yderliggående nationalistisk agitation og førte $\mathrm{i}$ august 1919 til dannelsen af Schleswig-Holsteiner Bund (SHB). Afstemningsresultatet $1920 \mathrm{blev}$ først accepteret efter 1945. Frygten for revolution og større socialistiske samfundsreformer var udbredt i alle dele af Tyskland. Det antidemokratiske Kapp-kup den 13. marts 1920 slog dybe skår i Slesvig-Holsten. Kuppet blev slået ned i løbet af få dages kampe og generalstrejke. For provinsens politiske fremtid blev det især af betydning, at afdelinger af militær og politi havde kæmpet mod de arbejdere, der strejkede eller direkte bistod regeringsloyale styrker militært. Denne borgerkrigskonfrontation skærpedes yderligere ved, at borgerlige militser (Selbstschutz) gik over til Kapp-styrkerne, mens landbrugsorganisationerne truede med levnedsmiddelstop som gengæld for generalstrejken. ${ }^{18}$

Kapp-kuppet var det første alvorlige mod det skrøbelige demokrati i Weimar. Interne tyske opgør havde ført til dannelsen af disse militser, der blev forstærket af hjemvendende soldater. Det tog tid at få disse afdelinger opløst, også efter kupforsøget. Efter dem kom ORGESCH (Organisation Escherich), en væbnet organisation, der fik betydelig udbredelse bl.a. i Flensborg-området og i Ditmarsken. Sammenslutningen blev opløst i 1921 og talte på sit højeste 30.000 mand.

Nogle medlemmer gik derefter over til andre nationalistiske og antidemokratiske grupper, der ofte også var antisemitiske. Og der var nok af politisk anløbne grupper og foreninger på yderste højre fløj. Andre foretrak terrorisme og politiske mord, som hyppigt forekom i republikkens første år. De gik til Organisation Consul. ${ }^{19}$ Den halvmilitare 
forening Stahlhelm oprettede en afdeling i Kiel allerede i 1919, men fik forst fra 1925-26 virkelig fremgang. Som helhed var det antidemokratiske, militaristiske og kejservenlige tendenser, der blev kultiveret $\mathrm{i}$ Slesvig-Holstens foreningsmiljøer og politiske debat. Socialdemokraterne og de smalle borgerlige lag, der støttede Weimarstyret, havde svært ved at klare sig $\mathrm{i}$ forhold til de massive grupper af indædte politiske modstandere, hvortil kom deres kommunistiske fjender. ${ }^{20}$

I den slesvig-holstenske gejstlighed var demokrati ikke særlig populært, det var til gengæld antisemitismen. Der herskede utilfredshed med den fjerne centralmagt i Berlin, den tyske grænseregion Nordmark blev ikke taget alvorligt nok. Og godsejere og bønder var bekymrede for fremtidens udstykningspolitik, der dog især kom til at betyde noget $\mathrm{i}$ det østlige Tyskland. ${ }^{21}$

Den politiske og sociale spænding i de første år efter 1918 blev ikke mindre af inflation, arbejdsløshed og stigende kriminalitet. Sikkerhedspoliti og ordenspoliti blev hårdt belastet af talrige arbejdsopgaver, spændende fra landarbejderuroligheder, jernbanestrejker til større skyderier med dræbte og sårede, således blev 7 demonstranter dræbt af politiet ved nytårstide 1920-21. 1921-23 var der hyppigt strejker og uro i Kiel. Ikke mindst i oktober-november 1923 gik det hårdt til. Der blev plyndret bagerier, slagterier og andre butikker. Det kom til svære sammenstød og skyderier ved opgør med arbejdsløse og politi. ${ }^{22}$ I november 1923 var brødprisen nået op på 80 milliarder rigsmark. Den lille mand, pensionister og middelklasse mistede deres opsparing under hyperinflationen 1922-23. Landbruget kom med nye trusler om leveringsstop og boykot i protest mod Berlins landbrugspolitik. ${ }^{23}$

Som helhed var Sydslesvig i tyverne præget af krigens mange eftervirkninger, derunder en forstærket politisk og social splittelse. Krisen banede vej for nazismen, men det var ikke mindst velindarbejdede ideologiske holdninger, erfaringer og traditioner, der førte til Hitlers bevægelse. Landbrugskrisen er kun en del af forklaringen på den stærke nazificering af landmænd, håndværkere osv. ${ }^{24}$

Ikke uden grund har man kaldt det daværende Slesvig-Holsten, der ikke kunne affinde sig med krigens nederlag og industrisamfundets nye tider, et betændt samfund. ${ }^{25}$

\section{De sorte faners tid}

Udviklingen i landbruget blev skæbnessvanger. Landmændene kom ganske vist af med deres gæld med hyperinflationen 1922-23; men både 
østpreussiske junkere og nordtyske landbrugere var meget sårbare. Endnu i 1924 så det ud til, at landbruget havde fået en god start; men det viste sig hurtigt, at ikke mindst det slesvig-holstenske produktionsapparat var meget konjunkturfølsomt, fordi det var så kapitalintensivt. Men trods importrestriktioner af forskellig karakter samt toldbeskyttelse førte landbrugskrisen, der også skyldtes utilstrækkelig produktionstilpasning og produktudvikling, til svære problemer. ${ }^{26}$ Den politiske uro, der fulgte, bidrog til Weimarrepublikkens fald. Krisen mærkedes for alvor fra efteråret 1927. Ledende repræsentanter fra landbrugets organisationer advarede om, at man nærmede sig en økonomisk og politisk katastrofe, hvis der ikke omgående gennemførtes en drastisk ændring af tysk landbrugs- og udenrigshandelspolitik. Imidlertid pressede mange landmænd på for en mere aktivistisk og yderliggående protestpolitik. Impulserne til en mere aggressiv aktionsform kom især fra Ditmarsken. Her havde en større demonstrationsserie været under overvejelse fra oktober 1927. Den 28. januar 1928 kaldte den ansete storbonde Otto Johannsen fra Büsum til demonstration over hele Slesvig-Holsten. Hans opfordring fik en uhyre gennemslagskraft. Den 28. januar 1928 mødte ikke mindre end 140.000 demonstranter i 20 byer i Sydslesvig og Holsten. Der blev krævet mere beskyttelse af landbrugserhvervet. Den ny bevægelse blev begyndelsen til enden for de mere moderate landbrugsorganisationers indflydelse og til en styrkelse af en ideologisk fanatisme, som der i forvejen var forudsætninger for. ${ }^{27}$

De følgende måneder blev slesvig-holstenske landbrugsorganisationer revet med i en omsmeltningsproces, der gradvist skulle forvandle det politiske landskab $\mathrm{i}$ regionen såvel som det øvrige Tyskland til ukendelighed.

Den danske konsulent Erik V. Poulsen, der arbejdede syd for grænsen, har til Rødding Højskoles årsskrift 1928 givet et signalement af udviklingen i Sydslesvig. Han skrev, at det var, som om en klam hånd havde lagt sig over det hele. Syd for grænsen var det de større gårde, der førte an. Nord for grænsen var man bedre stillet med hensyn til organisationer og skoler, der havde styrket det almene informationsniveau. "... Det er noget, tyskere ikke forstår, man evner ikke at gøre det jævne folk delagtigt $\mathrm{i}$ de fremskridt, der bliver gjort på landbrugets områder, at give nye teorier en praktisk anvendelig form. Så bliver det selvfølgelig kun de bedre uddannede kredse, der kan tilegne sig fremskridtene. Der blev f.eks. kun dyrket halvt så mange roer i Sydslesvig som i Danmark, det skadede planteavl og husdyrbrug. 
Såmetoderne var gammeldags, og det kneb med at holde roemarker og andre marker rene. Store arealer af den sydslesvigske sandjord lå hen i græs. Forårsarbejdet med jorden var man også traditionelt bagefter med. Derimod var specielt landmændene i Angel godt med, når det drejede sig om kontrolforeninger. Østpå, også i Slesvig gik det godt med kvægydelserne. Vestpå var det helt anderledes, i de to amter Sydtønder og Husum blev kun $4 \%$ af køerne kontrolleret. Der blev satset for meget på opdrætning og fedning af kreaturer, for lidt på mælkeproduktion. For Poulsen var der ingen tvivl, det, man trængte til, var en omlægning af produktionen.

Som nord for grænsen var landmændene nødt til at spare. "I Sydslesvig sparer man også. De daglige fornødenheder er, særligt på de vestlige egne, ikke ret store. Man bager selv sit brød, om aftenen spiser man de fleste steder boghvedegrød. Som kaffe bruger man endnu mange steder brændt rug. Brændsel får man fra tørvemosen. Biler, telefon og radio er der grumme få, der har.« Derimod brugte man alt for meget kunstgødning. Også svineproduktionen var lav. På sandjordsegne havde man kun en griseso eller to. Korntold og mellemhandlere betød høje kornpriser. Andelsslagterier var der ikke, og svineavlsmæssigt var der tale om produktion af svingende kvaliteter, derfor var grisene også i alle kulører. Som en anden samtidig iagttager bemærkede, landbrugerne var stræbsomme nok, men de manglede bl.a. afsætningsorganisationer, og der var for lidt forædling, for meget korn og kartofler i landsbrugsproduktionen. ${ }^{28}$

Forsøg på at reorganisere og styrke de traditionelle landbrugsorganisationer kunne ikke hindre en fortsat udvikling af yderliggående tendenser. Såvel den politiske højrefløj som den republikfjendtlige krigsveteranorganisation Stahlhelm, der nu stod stærkt i Slesvig-Holsten, havde skærpet kursen. I landbrugsorganisationerne kunne man endnu mindre end før enes om en fælles holdning. Som landbrugskrisen blev ved, blev landmændene endnu mere modtagelige for yderliggående paroler. Samfundet og det politiske system skulle ændres. Der var hverken tillid til Weimar eller til de traditionelle landbrugsorganisationer. Og ekstremistpropaganda havde der været nok af i de forskellige højreekstremistiske sekter.

Krisen satte skub $i$ arbejdet for at skabe en ny og mere aktivistisk ledelse i landbruget. Førende personligheder i de aktivistiske kredse var Wilhelm Hamkens fra Ejdersted samt Claus Heim fra St. Annen i den nordlige del af Ditmarsken. Wilhelm Hamkens var af gammel 
bondeslægt. Han havde været officer 1914-18, og efter kigen blev han medlem af organisation Erscherich og Stahlhelm. I løbet af krigsårene blev han også nazist. Claus Heim havde fået smag for radikale metoder fra sine år før verdenskrigen i Latinamerika. Nuancer var der nok af i den landbouro, der var ved at brede sig. Det var Hamkens mål at skabe en stærk antiparlamentarisk samlingsbevægelse, en "Landvolkbewegung «, der med protestaktioner kunne omforme stat og samfund til stærkt landbrugsvenlige organismer. I denne agitation vendte han sig mod stærkt ideologisk orienterede grupperinger som Tannenbergerne. Han frygtede, at deres ekstremisme kunne splitte den nye bevægelse. Det blev bestandig betonet, at den nye aktivistbevægelse ikke var som de traditionelle organisationer, der var ingen fast ledelse eller medlemsskare. Dr. Gerhard Stoltenberg skriver i sin bog om den, at som bevægelse gav den indtryk af noget uberegneligt og spontant. Hektisk aktivitet og pludselig ro kunne følge efter hinanden. I princippet afviste Hamkens i øvrigt vold som kampmiddel.

Fra efteråret 1928 iværksatte den nye protestbevægelses ledere talrige protestaktioner, skattenægterkampagner og forsøg på at stoppe krisens tvangsauktioner $\mathrm{i}$ landbruget, og denne radikalisering med dens mangeartede følger vakte bekymring i moderate og demokratiske kredse.

Især Claus Heim var aktiv i disse aktions- og obstruktionsaktiviteter. Han opstillede forskellige aktivistgrupper til at forhindre udpantninger og tvangsauktioner. Det var folk med gode forbindelser til de forskellige højreekstremistiske kredse. En stadig mere kritisk økonomisk situation, der kun blev afhjulpet marginalt af mere landbrugsstøtte, holdt kriseatmosfæren vedlige. Aktivismen var ikke mere til at dæmpe. Protestbevægelsen voksede og satte i løbet af foråret 1929 endnu stærkere kræfter ind på kampen for dens mål, der betød et opgør med statens organer. ${ }^{29}$

Protesteksplosionen i Slesvig-Holsten blev også fulgt med stor opmærksomhed af både den tyske og den udenlandske presse. Hamkens blev refereret for udtalelser om, at de russiske bønder havde hængt embedsmændene op i det nærmeste træ og andre aggressive udtryk. Regionen var blevet et kriseområde. Bevægelsens aktivister blev hyldet som helte og martyrer, når de blev dømt for at sabotere tvangsauktioner. Der var talrige eksempler på agitationens fanatisme. Sidst $\mathrm{i}$ januar 1929 mødtes Landvolk-aktivister i Læk i Sydtønder amtskreds få kilometer fra Tønder. Der var slagord mod demokratiet og jødehad. "Har man masserne, har man magten, og med magten følger retten, « sagde 
en taler. Ernst Bossen fra Karlum erklærede: "Vi går en socialisering i møde. Det er jøderne, der står bagved. Også den røde terror truer os.《

En tredje agitator sagde bl.a., at bestræbelserne gik ud på at befri den nordiske og germanske race for det jødiske blod. ${ }^{30}$

Det tidlige forår blev hedt. Protestbevægelsen forsøgte sig med noget nyt, mens aktivismen i øvrigt bredte sig til andre tyske landbrugsregioner. Den ny kampform var »Nothilfe«, og hvad man forstod ved denne form for "nødhjælp« kunne man erfare på 12 møder, bl.a. i Læk. De revolutionære grupper ville have magten i de lokale selvstyreorganer. Myndighederne slog imidlertid hurtigt til over for denne demonstrationsform, hvorefter de militante kræfter atter slog sig på udpantninger og tvangsauktioner. Radikaliseringen afspejledes ligeledes $\mathrm{i}$ bevægelsens ny avis Landvolkzeitung, der oktober 1929 allerede havde 10.000 abonnenter, hvilket var mange i de daværende magre tider. Større kampagner sattes $\mathrm{i}$ gang $\mathrm{i}$ forbindelse med retssagerne mod demonstranter og skattenægtere. Processerne blev brugt til politisk propaganda. Spredte moderate kræfter søgte f.eks. i Angel og Sydtønder at bremse de højreradikale, men havde ikke held eller politisk og organisatorisk styrke til det. Imens fortsatte radikaliseringen.

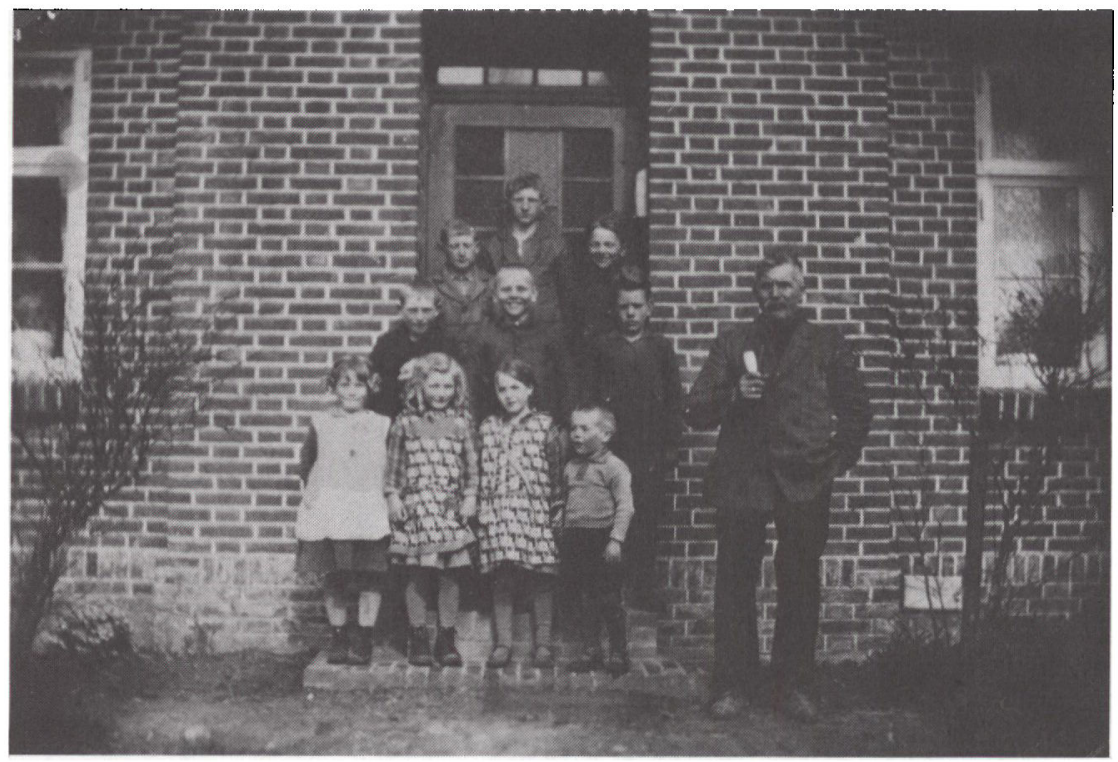

Vandreskole i Agtrup få kilometer fra Ladelund i begyndelsen af trediverne. (Privateje) 
Allerede i 1928 var der i et enkelt tilfælde blevet anvendt fyrværkeri. $\mathrm{Nu}$ gik man over til rigtigt sprængstof. I slutningen af januar 1929 havde en gruppe stjålet $50 \mathrm{~kg}$ sprængstof med sprængkapsler. Det blev gemt ved Peter Holländer på Karlum mark. Holländer modtog beæret sprængstoffet, han var iført sort tøj. Holländer var tillidsmand for Landvolk og Stahlhelm, der fra 1928 åbent bekæmpede det demokratisk-parlamentariske system. Den 6. april 1929 blev der kastet håndgranater mod politiske modstandere i Wesselburen. Den 23. maj fulgte et attentat mod landrådskontoret i Itzehoe, og det blev i de følgende måneder fulgt op med anslag bl.a. mod offentlige myndigheder og bygninger i Nibøl og Slesvig, og her spillede Peter Holländer en rolle. Attentaterne vakte stor opsigt og medførte, at der blev sendt betydelige politiforstærkninger til provinsen. 9-11. september blev 36 fra protestbevægelsen arresteret, derefter også Hamkens og Heim, så bevægelsens ledelse for en tid var slået ud. Men nye store demonstrationer med den sorte protestfane viste, at forbitrelsen over landbrugets situation var usvækket, og nu kom verdenskrisen. Retssagerne i forbindelse med attentaterne var en god anledning til at lave politisk propaganda, men der var andre, der fiskede $i$ rørte vande, ikke mindst nazisterne. ${ }^{31}$

Nazisterne havde tidligt forsøgt at etablere en partiorganisation $i$ området, fra 1926 oprettedes grupper i Kiel, Neumünster og Altona, og der var gode regionale forudsætninger for nazismen. Den senere Gauleiter i Slesvig-Holsten 1933-45 Heinrich Lohse blev en ganske effektiv kampagneleder, og allerede fra 1927 oprettedes flere partiafdelinger og mindre afdelinger af SA, Hitlers borgerkrigs- og terrorkorps. Lohse havde også gode personlige forudsætninger, idet han havde været med i det såkaldte Landespartei, hvor han havde knyttet værdifulde kontakter til politisk bevidste bønder. Partiet havde et strøg af agrarfascisme og var antisemitisk. Demokrati var noget jødisk, man ønskede $\mathrm{i}$ stedet en stænderstat. Mens nazisterne andre steder satsede på folkemasserne $\mathrm{i}$ de store byer, satsede Lohse på de betrængte landmænd. Da de kriseramte landmænd begyndte at miste deres traditionelle tilhørsforhold til partier og organisationer, var der et godt potentiel, ikke mindst i de magre egne. Fra 1928 begyndte nazistpartiets medlemstal at vokse hurtigt. SA i Slesvig-Holsten blev udbygget. Kendte landmænd og soldater begyndte at gå over til partiet. ${ }^{32}$

Blodige sammenstød med politiske modstandere styrkede tilgangen af nye medlemmer. I de magre geestegne gik også husmænd og landarbejdere over til nazisterne. Fra juli 1929 åbnede de en offensiv i Sydslesvig, med talrige møder, bl.a. i grænseegnene. Alene i 1930 blev der 
holdt 50 møder i Sydtønder amt, hvortil kom, at andre yderliggående grupper også førte mange kampagner. I 1931-33 opstilledes der i Sydtønder amt som $\mathrm{i}$ andre egne SA-enheder, så partiet rådede over et egentligt magtapparat. ${ }^{33}$

Landvolk-bevægelsen havde gennem sine aktioner skabt anarki i samfundsorganer og traditionelle landbrugsorganisationer. De urolige forhold gav sammen med verdenskrisen gode vakstbetingelser for nazismen netop i de områder, hvor bevægelsen havde opereret.

\section{Den politiske vold vokser}

De første efterkrigsår havde været præget af opløsningstendenser, revolutionær gæring og undertiden af uroligheder og væbnede sammenstød. Landvolk-bevægelsens omfattende aktiviteter havde medført stærk uro og demonstrationsaktivitet samt attentater, der mere var bemærkelsesværdige ved deres politiske og propagandistiske end deres tekniske gennemslagskraft. Den amerikanske samfundsforsker Timothy Alan Tilton betoner da også, at de militante bondeoprørere gjorde et godt forarbejde for nazismen og dens metoder. Forståelsen for nazistisk vold som politisk kampmiddel var god i slesvig-holstenske kredse. ${ }^{34}$

De nazistiske kampformer udløste en overgang i 1932 et forbud mod SA og SS. SA talte da allerede 400.000 mand i hele Tyskland. Ophævelsen af dette forbud kort tid efter frembragte omgående en større voldsbølge. Ikke mindst i Slesvig-Holsten, hvor nostalgien efter det militaristiske kejserrige fra før 1918 florerede, spillede militært prægede politiske demonstrationer en betydelig rolle. Og voldshandlinger engagerede folk, så man kunne rekruttere nye medlemmer. Ud over nazisterne var det kun kommunisterne, der betjente sig af egentlige politiske drab. De så også socialdemokrater som fjender næsten på linje med nazister. For nazisterne var alle andre fjender, dog især venstrefløjens folk, men undertiden kunne de også overfalde de højreorienterede tysk-nationale, deres konkurrenter til højre.

Det er ikke for meget at sige, at politiet især 1931-32 var ved at blive overbelastet af den voldsomme uro overalt. Der var også interne spændinger, mange tidligere regeringstro politifolk blev nazistiske. Ser man på f.eks. Flensborg politis støtteudrykninger til andre politikredse, kan man konstatere, at tiden december 1931 - september 1932 næsten var én stor udrykning. Slesvig-holstenske historikere er i de senere år i stigende grad begyndt at interessere sig for samtidshistorien. Wolfgang 
Kopitzch har $i$ en afhandling givet et indtryk af dimensionerne $i$ de blodige kampe i juli 1932. Den 11. juli 1932 havde SA samlet 1500 mand i Egernførde. De stormede den lokale fagforeningsbygning, hvor der var møde. To landarbejdere blev dræbt. Dagen efter blev en kendt kommunistisk funktionær fundet dræbt. Ved begravelsen 15. juli 1932 kom det til et stort sammenstød mellem følget til begravelsen og SA. ${ }^{35}$

Efter den nazistiske magtovertagelse i 1933 kom den brune hævn. Talrige mistænkte blev arresteret, den 1. august samme år blev f.eks. fire dødsdømte kommunister halshugget i Altonas fængsel. ${ }^{36}$

Altona er i dag indlemmet i delstaten Hamborg. Det har taget sin tid for den gamle hansestads styre at vedkende sig fortiden, derunder de tidligere koncentrationslejre »Kolafu«, koncentrationslejren og Gestapofængslet Fuhlsbüttel samt Neuengamme. I maj 1984 satte Hamborgs regering sig $\mathrm{i}$ bevægelse for at få gamle nazistiske domme omstødt, de dødsdomme over kommunister, der faldt i kølvandet på "Blodsøndagen i Altona ${ }^{37}$

\section{Demokratiets sidste kriser}

Weimarrepublikkens parlamentariske system fungerede ikke de sidste tre år over til Hitlers magtovertagelse. Dr. Brüning førte 1930-32 en kras deflationspolitik. Denne ekstreme sparepolitik gik til marv og ben. Brünings politiske initiativer, der i et vist omfang gav succes, var afhængige af den aldrende præsident Hindenburgs støtte. I $1932 \mathrm{lod}$ Hindenburg Brüning falde, bl.a. fordi man gik de østprøjsiske storgodsinteresser for nær, regeringens udstyknings- og godssaneringspolitik havde såret junkerne. Dertil kom bl.a. meningsforskelle over det udstedte forbud mod SS og SA. Hindenburg og indflydelsesrige kredse i præsidentens omgivelser folte, at det var urimeligt at lade SA og SS forbyde, når det socialistiske og republikvenlige Reichsbanner fik lov til at fortsætte sine aktiviteter. Præsident Hindenburg og den øvrige højrefløj opfattede først og fremmest de brune stormtropper som forsvarsvenlige, der blot skulle styres. ${ }^{38}$

Efterfølger blev den adelige kavalleriofficer Franz von Papen, der i sine bestræbelser for at tæmme nazisterne undervurderede det revolutionære indhold i Hitler-bevægelsen. Den politiske ustabilitet i Prøjsen førte til regeringsindgreb mod det siddende styre. Med præsidentens billigelse blev regering og administration afsat ved en slags kup, og en borgerlig administration overtog magten. Det preussiske landdagsvalg 
i april 1932 havde givet risiko for en nazistisk ministerpræsident, det var i hvert fald oplægget til kuppet. Politiet var kampklart den 20. juli 1932 med panservogne og maskingeværer, men den socialdemokratiske regering veg uden om en egentlig kamp. Og den splittede arbejderbevægelse havde ikke tilstrækkelig mod på en generalstrejke og uroligheder i protest. ${ }^{39}$

Elendigheden toppede i sommeren, det samme gjorde det nazistiske stemmetal, der ved rigsdagsvalget 31. juli 1932 nåede op på $37 \%$. For provinsen Slesvig-Holstens vedkommende var der tale om et usædvanligt gennembrud. Fra 4\% i 1928 og $27 \%$ i 1930 kom man nu op på $51 \%$. Særlig stærkt stod nazisterne i de tyndt befolkede magre geestegne, hvor man kunne nå op på $78.9 \%$ af stemmerne. ${ }^{40}$ Reelt begyndte det nazistiske stemmetal allerede at gå ned senere på året, da industrien så småt begyndte at gå lidt bedre.

Ensretningen i Slesvig-Holsten gik hurtigere end mange andre steder. Forudsætningerne var til stede. Det store flertal var gået over til Hitler. Antikommunismen var stærk, demokratiske holdninger svage. I august 1932 blev socialdemokratiske aviser en overgang forbudt på grund af deres kritik af kuppet mod den preussiske regering. ${ }^{\mathbf{4 1}}$

Efter von Papens korte regeringstid fulgte et mellemspil med Kurt von Schleicher; men omsider kom den 30. januar 1933 Adolf Hitler til magten støttet af den tysk-nationale højrefløj. Alle politiske bevægelser, viste det sig, havde grundigt undervurderet nazistisk magtvilje og taktik. De socialrevolutionære elementer i nazibevægelsen var gledet $i$ baggrund, og deres talsmænd blev likvideret under nedkæmpelsen af SA-lederne i 1934. Theodor Steltzer, der var borgerlig landråd i Rendsborg, til han blev afsat i 1933, og den første slesvig-holstenske ministerpræsident efter 1945, skriver i sine erindringer, at nazisternes styrke og magtvilje blev stærkt undervurderet. Mange modstandere kunne simpelt hen ikke forestille sig, at en stat domineret af forbrydere kunne fungere i længere tid, systemet måtte bryde sammen. Tillige betød den systematiske terror og en stadigt voksende hær af stikkere, at der altid måtte udvises den største forsigtighed. Også af den grund var oppositionen mod Hitler fra første færd svag. ${ }^{42}$

Nazisterne var magtbevidste fra første færd. Fra 26. marts 1933 begyndte ensretning og centralisering af politiet i provinsen SlesvigHolsten, og de blev militært organiseret og udrustet, bl.a. med maskingeværer og granatkastere. Demokratiske elementer blev systematisk udrenset, alene i Kiel blev over tusind mand fjernet. Folk fra SA og Stahlhelm blev hjælpepoliti. Slesvig-holstenske politiformationer 
deltog i besættelsen af Sudeterlandet, Østrig og Tjekkoslovakiet. Fra 1939 opstilledes enheder til besættelsesopgaver i andre lande, derunder partisankrigsførelse. ${ }^{43} \mathrm{Og}$ så var der alle fængslerne og de nye koncentrationslejre. Der var lidt flere af disse KZ-lejre, end man hidtil har kunnet læse sig til i den mere traditonelle historieskrivning syd for grænsen. Det gik i første omgang især ud over kommunisterne og socialdemokraterne, der kom til holstenske lejre og til Fuhlsbüttel i Hamborg. Den canadiske historiker Lawrence Stokes har som eksempel taget den lille by Eutin, der allerede fra sommeren 1932 havde fået nazistisk styre. April 1933 - maj 1934 havde Eutin en af de såkaldte "wilde Lager« med 3-400 fanger. Nazisterne bekendtgjorde officielt, at fangerne havde fået konstruktivt arbejde. Lejren var i øvrigt selvfinansierende. Udnyttelse af den billige arbejdskraft samt økonomisk afpresning af fangerne var en god forretning. ${ }^{44}$

For de arbejdere, der var kommunister, socialdemokrater eller blot frihedselskende, var nazismen en trussel. Nazisterne ville ikke klassekamp, men race- og folkefællesskab. 1. maj, arbejdernes dag, blev nazisternes festdag. Det nationale folkefællesskab for arbejderen og direktøren skulle praktiseres. 2. maj $1933 \mathrm{blev}$ fagforeningerne overfaldet, og snart var alle arbejderoganisationer forbudt, nazisterne havde sat sig på det hele. Myndighederne kom til at regulere lønninger og arbejdsforhold. Det nye system betød en form for statsligt stavnsbånd, hverken landarbejdere eller medarbejdere $\mathrm{i}$ industrien kunne nu uden videre flytte til en ny og mere attraktiv arbejdsplads, men de kunne stadig blive fyret af nazistiske partifunktionærer af politiske grunde. Fra 1938 kunne tyske arbejdere udskrives til befæstningsarbejder overalt. $^{45}$

For landbruget syntes naziperioden i første omgang en gylden tid. Efter 1933 ensrettedes landbrugsorganisationerne, en ny arvegårdslovning havde stor psykologisk effekt, landbrugets gæld blev saneret, og de ny arvebønder skulle være en nazistisk elite. Der blev bygget veje, efterhånden især militærveje. En anden uhyre vigtig effekt var den, der blev fremkaldt af udstykningsprojekter. Det største enkeltforetagende var den såkaldte Adolf-Hitler Koog. Det gav arbejde til mange, og propagandavirkningen var også betragtelig; men uden arierattest fik man ikke foden under eget bord. Arbejdskraftmangel prægede landbruget $i$ trediverne, men blev $i$ et vist omfang afhjulpet af folk fra Arbeitsdienst og skolebørn. Den blev ikke mindre fra 1939, men de indkaldte blev erstattet af krigsfanger og civile, der ikke blev behandlet lige godt. Klaus J. Lorenzen-Schmidt bemærker lidt maliciøst, at landbefolk- 
ningen så positivt på meget i nazistisk agrarpolitik, også længe efter krigen, selv om systemet havde kostet utrolig meget også for denne befolkningsgruppe. ${ }^{46}$

\section{Vejen til Ladelund}

„Baggrunden for, at jeg kom til at bo i Ladelund var, at trods det, at der $\mathrm{i}$ årene efter 1920 kun var gjort grumme lidt for Ladelund og de omliggende landsbyer, var der her et støt stemmetal ved valgene. Der var holdt enkelte møder, og efter 1924 havde skiftevis lærer Ejerslev og jeg nogle år holdt vandreskole for børnene fra enkelte danske hjem, af unge var der så godt som ingen, der sluttede sig til; men der var nogle prægtige gamle og et par unge lovende hjem i sognet, og så talte både tyske og danske dansk.« (dvs. sønderjysk) ... »Let var det ikke at bryde op fra Flensborg, hvor jeg havde haft et godt værelse, hvor jeg havde gode venner og hvor jeg levede med $i$, hvad der skete $i$ danskhedens højborg, når jeg ikke var ude omkring på landet. Det var ikke morsomt at begynde ude et afsides sted med en fjendtlig tysk befolkning og $\mathrm{i}$ en dårlig bolig. ${ }^{47}$

Vejen til Ladelund var ikke uden svinkeærinder. Der var et ophold på Statens Lærerhøjskole under meget spartanske forhold. I det hele taget var vandrelærervirksomheden måske ofte underholdende, men både fysisk og psykisk ganske krævende, og man spandt ikke ligefrem guld på den. Min fars omflakkende vandrelæreraktivitet varede i første omgang fra 1921 til 1926. I denne periode havde han i øvrigt ivrigt indsamlet lokale sydslesvigske sagn til Dansk Folkemindesamling. Der blev bl.a. tid til lærergerning på Krabbesholm højskole, Sorø højskole og Rens efterskole samt hjælpearbejde i det lille fyrstendømme Lichtenstein, der havde været udsat for en naturkatastrofe. ${ }^{48}$ Han erhvervede sig hurtigt en omfattende venne- og bekendtskabskreds og var meget politisk og litterært interesseret. Han forstod og kunne læse tysk, kunne også gøre sig forståelig, men noget naturtalent til tysk tale var han ikke ligefrem.

I 1929 kom han atter til Sydslesvig, og nu blev de lokale forbindelser både nord og syd for grænsen videreudviklet, ikke mindst var der $\mathrm{i}$ trediverne en tæt kontakt til Rødding højskole, Rens efterskole, hvor han havde enkelte timer, samt til de engagerede unge fra studenterforeningen Heimdal. Der var meget spræl i Heimdal-studenterne. De lærte en del om de nøgterne realiteter $\mathrm{i}$ vilkårene syd for grænsen og bidrog 
i øvrigt med fest og underholdning i Agtrup, Ladelund, og hvor de ellers kom frem $\mathrm{i}$ de gennemgående uhyre beskedent stillede danske hjem. ${ }^{49}$ Opmærksomme iagttagere bemærkede også, at foruroligende træk i udviklingen begyndte at vise sig. Således skrev forstander Hans Lund november 1930 følgende i Rødding højskoles årsskrift:

"... Men i de sidste måneder er tunge uvejrsskyer igen trukket sammen over os. En økonomisk krise har sat voldsomt ind, så mange hjem igen ligger i farezonen, og de europæiske forhold synes så forviklede som nogensinde. I Tyskland vokser et parti, nationalsocialisterne, sig stort i løbet af nogle måneder og synes nu at feje alle besindighedens og fredens kræfter til side. Hvad bærer dette i sit skød? Revolution og ny krig? De kommende måneder, som vort nabofolk må gennemleve med store folkeslag på hungerens grænse, vil bringe svaret. Vi gør vel $i$ at huske, at det svar også bliver et svar med bud til os. Europa hører så nøje sammen, at det, der bliver skæbne for den ene, også på en eller anden måde bliver det for den anden. En alvorsfuld og urolig baggrund for en skoles fredelige gerning! « 50

Det mærkedes også, at det sydslesvigske samfund fik sin del af de svære økonomiske og sociale problemer. Der herskede stor fattigdom i tyvernes Flensborg, der var unge og underernærede arbejdsløse. "Vi blev overløbne af tyske tiggere og trængende, « skrev pastor H. F. Petersen. ${ }^{\text {soa }}$

Også i det danske skolevæsen registreredes, at adskillige børn led under de dårlige ernæringsvilkår under og efter den første verdenskrig. Der var hungermarcher $\mathrm{i}$ byerne både $\mathrm{i}$ tyverne og trediverne. Langt op i trediverne kan man i Duborgskolens årsberetning læse, at en stor del af børnene og deres forældre levede $\mathrm{i} ø$ konomiske vanskeligheder, der giordet det vigtigt at sikre en fortsat børnebespisning (varm mælk og et par tørre rundstykker - i børnehaverne grød eller vælling -) begrænset til de dårligst ernærede og mest trængende elever. Rundt regnet en tredjedel af børnene fik varige forstyrrelser i legemlig udvikling som følge af dårlige økonomiske og sociale forhold.

De vestlige egne var så udpræget kriseegne, både politisk og økonomisk. Efteråret 1931 var der megen uro på Læk-Agtrup-Ladelundkanten. Landmændene demonstrerede på trods af det eksisterende demonstrationsforbud. Midt i oktober oprettedes Notgemeinschaft, altså direkte udfordring til myndighederne, i Ladelund og nabosogne, i Læk optrådte kendte yderliggående bondehøvdinge. I november 1931 kunne man opleve en sådan protestforsamling i Ladelund, hvor der var lussinger i luften. Da Ernst Bossen fra Karlum skulle ind til Læk for at 
afsone $4 \frac{1}{2}$ måneds fængsel for medvirken ved bombeattentater, blev han fulgt af en stor skare af egnens bønder til hest og til vogns; men ved Karlum skov blev de standset af gendarmer med løftede revolvere og fik først lov at passere efter nogen tid og da kun én med to minutters mellemrum. ${ }^{\text {sob }}$

For Ladelund og de andre geestlandsbyer blev selve Hitlers magtovertagelse nærmest en formalitet. Allerede i november 1932 havde der været $84,6 \%$ nazistemmer. For det svage og ikke mindt $i$ landdistrikterne meget sårbare mindretal blev det en vanskelig periode. For dem, der havde været i krig for kejser Wilhelm 1914-18 eller blot kendte til tysk-nationalistiske traditioner, opstod betænkeligheder. Allerede i 1928 havde man i Flensborg oplevet SA-folk med faner til gudstjeneste. I foråret 1933 viste SA, SS, Stahlhelm og Reichswehr, hvorledes man kunne iscenesætte storslåede patriotiske feltgudstjenester. Det oprørte således Jens Andresen fra Agtrup heftigt, at krigsbegejstringen atter dyrkedes. ${ }^{50 c}$

Min far prøvede at løbe gennem Flensborgs gader for at undgå at heile for SA-optog. Gjorde man det ikke, blev man slået ned. Men ellers blev han ikke generet synderligt lokalt, bortset fra engang i 1932, da han havde tyske lærere som gæster. Ved denne lejlighed fik han en stor sten gennem vinduet, der kunne have forvoldt alvorlig personskade. Gendarmen fik aldrig sagen opklaret. Formålet var formentlig ikke at ramme den danske lærer, men at skræmme tyskerne. ${ }^{500}$

Informationsniveauet vedrørende tyske forhold og nazismen i 1933 varierede meget i Danmark, men det skortede ikke på interesse i højskolekredse. Dette illustrerede et brev fra højskolelærer Arne Brandt Pedersen, Rødding, fra 9. august 1933.

Arne Brandt Pedersen var interesseret i at skrive en lille bog om den brune revolution og ønskede materiale fra Sydslesvig. Han skrev bl.a.: "... Kunne De ikke en dag, når De har lidt tid, sætte Dem hen og skrive mig et brev om tilstandene i Tyskland i øjeblikket - efter revolutionen? Er begejstringen for Hitler ved at kølnes? Er den hemmelige opposition i tiltagen? Har han gennemført nogle af sine programpunkter endnu? Eller er de opgivet? Udstykning f.eks.?

Er der tale om splittelse inden for partiet - mellem en radikal og en konservativ fløj?«

Videre hed det bl.a. i brevet: "... Mon der kan oplyses noget om, hvor mange der er i koncentrationslejr, eller hvor mange slige lejre der er? Og om hvor mange flygtninge, der har forladt Tyskland?

Har De talt med nogen, der har været i koncentrationslejr? Så ville 
det jo være interessant med oplysninger derfra. - De forærede mig nogle illustrerede blade med billeder om racespørgsmål o.lign. Træffer De på mere af den slags, kunne jeg altså nok bruge noget ... $\ll^{51}$

\section{Forsamlingshuset Kirkevang}

I 1930 havde Maren Sørensen rejst sit Valsbølhus. Men der var stadig brug for flere samlingssteder til folkelige arrangementer, gymnastik, folkedans, sløjd, møder. 1933-34 arbejdede et lokalt udvalg med planen om et forsamlingshus. De første bidrag blev tegnet blandt de danske i Agtrup, Karlum, Bramsted og Ladelund. Trods de magre tider var der også bidrag fra de helt unge, både karle og piger, som det hed dengang, gav af deres knappe timarksedler til bygningen. Som det mest centrale sted valgtes Ladelund. En byggegrund ved en trekant, hvor tre veje mødes, blev købt. I grundbogen stod den indført som Kirkevang, et gammelt dansk marknavn. Det kaldte man så det nye forsamlingshus, der i løbet af sommeren 1934 blev opført af arkitekt Jep Fink, Åbenrå og lokal arbejdskraft. Det var et overordentlig skrabet byggeri, svarende til den lokale befolknings beskedne økonomiske

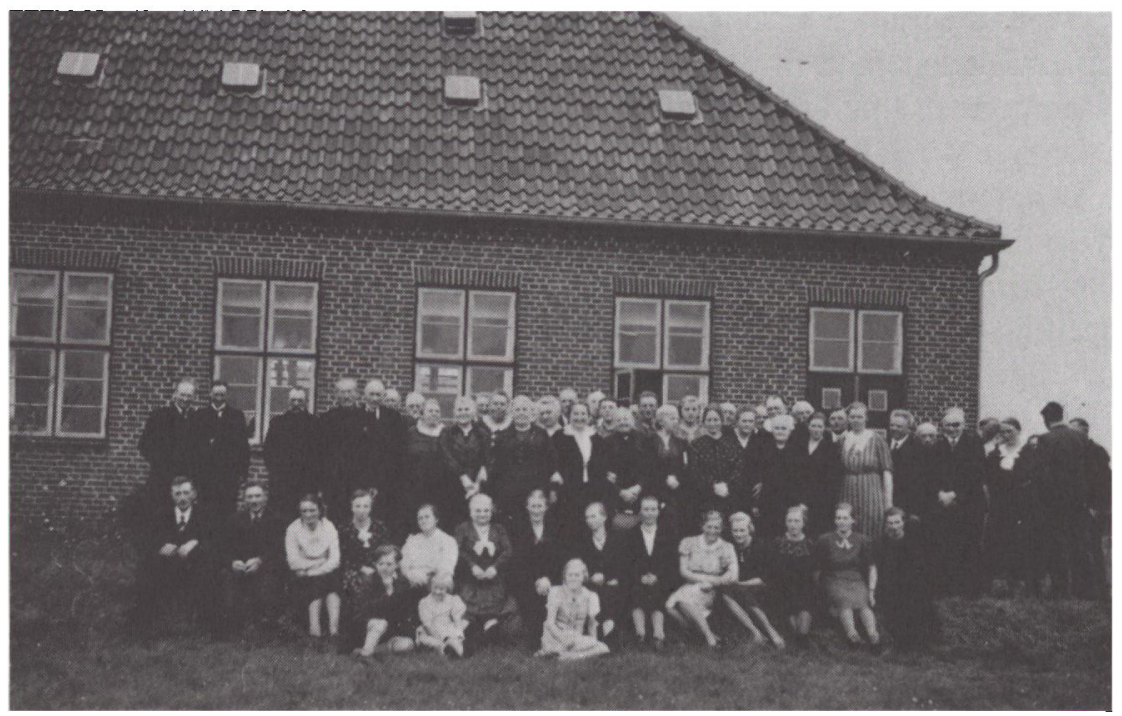

Deltagerne $i$ indvielsesfesten for forsamlingshuset Kirkevang den 9. september 1934. (Privateje) 
formåen. Husets centralvarme blev $i$ første omgang finansieret ved vandrelærerens personlige gældsstiftelse. Et par tusind kroner var mange penge den gang.

Ved indvielsesfesten søndag den 9. september 1934 prædikede pastor H. F. Petersen, Harreslevmark, over dagens tekst. Professor Knud Fabricius talte om Kær herreds historie. Højskoleforstander Lars Bækhøj holdt foredrag om nordisk ungdomsopdragelse. Desuden blev der holdt en snes mindre taler og overbragt talrige skriftlige og telegrafiske hilsener. Indvielsesfesten sluttede med underholdning om aftenen. Den samlede ikke mindre end 3-400 deltagere, mere end dobbelt så mange, som den nye mødesal kunne rumme; men vejret var godt, så arrangementet kunne afvikles i fri luft. 4-5 landjægere fra det lokale politi patruljerede under festen frem og tilbage på vejen, men der var ingen optræk til forstyrrelser fra tysk side. ${ }^{52}$

Tirsdag aften efter indvielsen holdtes der atter fest, denne gang for håndværkerne samt danske og tyske naboer. Den forløb fornøjeligt og fredeligt. "Vi drak kaffe og dansede til grammofonmusik skiftevis: "Se, her danser bedstefar « og "Das ist die Liebe der Matrosen!« Nu er festdagene forbi, og det daglige arbejde i Kirkevang begyndt. Det er mit håb, at her $\mathrm{i}$ det nye smukke samlingssted $\mathrm{i}$ de delvis dansktalende sogne i Kær herred dansk sprog og sind må styrkes og forståelsen mellem de to grænsefolk fremmes.«

Med forsamlingshuset havde man fået kirke- og mødesal, sløjdlokale og en lille lejlighed til vandrelæreren. Næste skridt blev oprettelsen af Kær herreds ungdomsforening i oktober 1934. Der kom gymnastik, ugentlige sløjdaftener og folkedans. De unge fra foreningen kom regelmæssigt med til Det unge Grænseværns stævner nord for grænsen. Men forsamlingshusets økonomi forblev de første år uhyre anstrengt. De store nationale foreninger nord for grænsen tøvede med at give egentlig støtte. Derfor kom foreningen To Løvers hjælpsomhed overordentlig kærkomment. Min fars forbindelser til studenterforeningen Heimdal og To Løver havde været nære i mange år. Nu gik To Løver efter et besøg i Ladelund i september 1935 aktivt ind med økonomisk hjælp. To Løvers bestyrelse besluttede 9. januar 1936 efter møder med H. F. Petersen og sekretær Fr. Petersen, der begge havde peget på Kirkevang som trængende til støtte, at der skulle ydes tilskud til driften. Denne bistand udviklede sig siden til varig hjælp til de danske aktiviteter, til forsamlingshus, ungdomsskole og privatskole. Først i løbet af 1937-38 kom de store nationale foreninger med $\mathrm{i}$ arbejdet på at sikre Kirkevangs betrængte økonomi. ${ }^{53}$ 


\section{Chikaner og brevsag}

Det danske mindretal blev tolereret, men også chikaneret af nazisterne, og småfolk var sårbare. Det oplevede de spredt boende dansksindede familier i landsognene adskillige eksempler på. Ved en oplæsningsaften i Aventoft sidst i oktober 1933, kom gendarmen fra Nykirke og en stor SA-mand (hjælpepolitibetjent) på besøg. Han opnoterede samtlige mødedeltageres navne. I november måtte en mand efter gentagne trusler fra en ung nazist tage sin 15-årige søn til Danmark. Den unge nazist havde truet med at jage en dolk gennem ribbenene på drengen.

Januar 1934 blev familien Berg i Agtrup ramt af nazistisk uvilje. Den lokale afdeling af den stærkt højreorienterede veteranorganisation Stahlhelm meddelte Berg, at han ikke havde stemt ved valget 12 . november 1933, og at han derfor var blevet smidt ud af organisationen. Det betød, at han hverken fik arbejde eller understøttelse. Fru Berg mistede af samme grund skolerengøringen, der indbragte hende 20 mark om måneden. Hun havde dog fået lov til at beholde avisombringningen. Det hedder til slut i dagbogsnotatet om dette $"$ Strenge tider. I går er van der Lubbe (dødsdømt efter rigsdagsbranden) halshugget ${ }^{54}$

Kort tid efter indvielsen af Kirkevang fulgte en episode, der gav uventet og uvelkommen genlyd både nord og syd for grænsen. Den gav et glimrende indtryk af samarbejdet mellem tyske nazister i Nordslesvig og Slesvig-Holsten samt det udbredte overvågnings- og stikkervæsen, nazisterne betjente sig af. ${ }^{5}$ I Dansk Skoleforenings årsberetning 1934-35 berettedes bl.a. om kontakten nordpå til de danske folkehøjskoler. Denne forbindelse mellem folkehøjskolen og de danske sydslesvigere var blevet udbygget også efter 1933.

Således var der blevet holdt et møde den 30 . oktober 1933 , og et nyt møde den 2. september 1934 medførte betydelig offentlig interesse. Skoleforeningens årsberetning fortalte kort, at et fortroligt brev med referat fra dette kontaktmøde for højskolefolk og sydslesvigere var blevet opsnappet og offentliggjort i det tyske mindretals avis Nordschleswigsche Zeitung. Sagen vakte betydelig opsigt nord for grænsen og virkede trykkende syd for grænsen. ${ }^{56}$

Det var Borgerforeningen i Flensborg, der havde stillet de ydre rammer for mødet den 2 . september til rådighed. Til stede var mange danske skolefolk og sydslesvigere, og debatten prægedes ikke af lutter harmoni. Redaktør Ernst Christiansen kom for skade at erklære, at man ikke måtte undervurdere nationalsocialismen, der var ting, der 
kunne bruges. Denne udtalelse førte til krasse bemærkninger fra andre mødedeltagere. Den danske førstepræst i Flensborg C. W. Noack konstaterede tørt: "Hvis man kan søge efter idealer i NS, så kan jeg ikke arbejde her.« Min far sagde ifølge referatet, at man burde fă en kommunistisk taler næste år, så alle problemer kunne blive belyst.

Nordschleswigsche Zeitung kunne den 18. september 1934 bringe en artikel med referat af mødet. Nordschleswigsche Zeitung fremhævede, at Lindstrøm havde bedt om en kommunistisk taler. Deltagerne i det fortrolige møde var ikke ligefrem begejstrede ved situationen. Trygheden blev ikke større, da det siden viste sig, at det fortrolige referat var gået til det nazistiske hovedkvarter, til Dr. Sievers på Flensborg rådhus.

Sagens forløb blev opklaret, da der blev indgivet politianmeldelse, fordi Jørgine Abildgård på Snoghøj gymnastikhøjskole ikke havde modtaget sit referat fra Flensborgmødet. Politiets efterforskninger i sagen førte til enkefru Henriette Røwekamp, Åbenrå, og naturligvis til redaktør Dr. Harboe Kardel, der i Nordschleswigsche Zeitung havde offentliggjort referatet og krænket brevhemmeligheden. Brevet var ifølge fru Røwekamp blevet fundet af hende og hendes svigerdatter og var derfra nået til den tyske avis. Under afhøringen i retten oplyste Dr. Harboe Kardel, at brevet var blevet overgivet til VDA (den nazistiske organisation, der varetog Hitler-Tysklands forbindelser med det tyske mindretal), dvs. til topnazisten Dr. Sievers. Harboe Kardel blev spurgt, om dette skete for at skade Noack og Lindstrøm. Det havde han ikke noget svar på. I Nordschleswigsche Zeitung forsvarede Harboe Kardel sig efter fattig evne, men det var ikke så let at forsvare åbenlyse krænkelser af brevhemmeligheden. ${ }^{57}$

Både Dannevirke og Hejmdal kritiserede i skarpe vendinger Harboe Kardels meriter. Hejmdal skrev således den 14. november 1934 i en kommentar, at det tyske mindretal ikke skulle have en fortrinsstilling i forhold til det danske flertal. Det hed bl.a. "At tilhøre det tyske mindretal skal ikke være en formildende omstændighed, lige så lidt som det skal være skærpende. Lige ret for alle!«

Den 16. november 1934 kritiserede Hejmdal atter skarpt Harboe Kardel og spurgte, hvorfor Volksbund für das Deutschtum im Ausland (VDA) skulle have det brev. Bladet erklærede, at den tyske redaktør ikke var nogen forfulgt martyr og skrev: "Det vil forekomme mange, at red. Harboe Kardels handlemåde i betænkelig grad nærmer sig spionagetjeneste!« Hejmdals lederskribent konkluderede, at sagen åbenbarede spillet mellem tyske nordslesvigere og centralen i rådhuset i Flensborg, dvs. den nazistiske ledelse. 
Da sagen var opklaret, kom den hurtigt til doms. På det sidste retsmøde inden domsafsigelsen i begyndelsen af december 1934 erklærede anklageren, politiadjudant Fritz Jacobsen, at der burde sættes en stopper for nazisternes angiveri og spionage. Han krævede derfor lovens strengeste straf. Harboe Kardel erklærede på retsmødet den 4. december, at spionage og angiveri lå ham, der havde været frontsoldat, fjernt.

Dagbladet Hejmdal gjorde $\mathrm{i}$ forbindelse med referatet af retsmødet opmærksom på, at en af mødedeltagerne fra den 2. september, efter at brevet var blevet opsnappet, var blevet skygget af det politiske politi syd for grænsen.

Ved retten i Åbenrå faldt der dom i brevsagen den 5. december 1934. Redaktør Dr. Harboe Kardel fik en bøde på $800 \mathrm{kr}$ for at krænke brevhemmeligheden, enkefru Røwekamp slap med $300 \mathrm{kr}$ i bøde. Harboe Kardel fik at vide, at han udelukkende slap så billigt, fordi han var ustraffet. 58

Min far var i lang tid trykket over situationen; men Noack sagde, at han blot skulle lade som om intet var hændt. Det viset sig i øvrigt siden, at den såre uskyldige vandrelærervirksomhed faktisk af nazisterne blev overvåget nøje, næsten fra kaffekop til kaffekop.

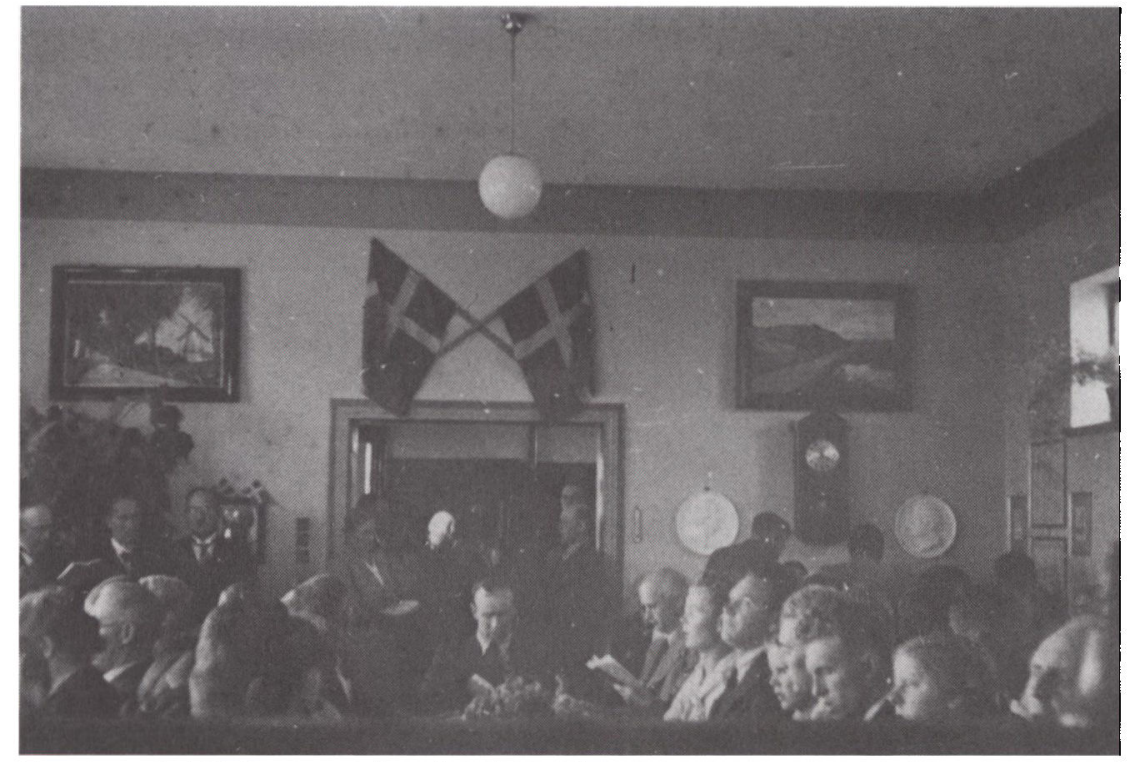

Dansk mode $i$ Kirkevangs tidlige \&r. I forsamlingshuset kunne man tale frit, og det var der behov for allerede 1933-34. (Privateje) 


\section{Det danske arbejde i de første Hitler-år}

Det kan ikke forundre, at nazismen af det spæde danske mindretal i Sydslesvig blev anskuet med skepsis og tøven. Det havde taget tid at få lov til at virke nogenlunde frit selv under den demokratiske Weimarrepublik. Nu herskede traditionelt yderliggående slesvig-holstenere og militante nazister, der ville have grænserevision.

Et par glimt fra Dansk Skoleforenings årsberetninger røber lidt af stemningen:

»Det var med nogen ængstelse, vi begyndte det nye skoleår.

Den nationale revolution var gennemført i Tyskland. Ingen kunne se, hvorhen det bar, og hvad det ville betyde for det danske mindretal. Sindene var stærkt i oprør, og mange angstelige sjæle var bange for fremtiden. Ville vore folkefæller modstå det tryk udefra, eller ville det hele blive fejet til side? .... (39 $^{39}$

"Alt står i nazismens tegn, også det danske arbejde er påvirket af denne bevægelse. - Der er vel kun få, der har forladt de danskes rækker og er gået til nazismen af overbevisning; men en del har gjort det af frygt for, at de ikke kunde fă arbejde, når de ikke marscherer under hagekorset, en frygt der har vist sig ikke at være ugrundet.

Nu dukker da spørgsmålet frem: kan een, der på en eller anden måde står inden for bevægelsen, enten i SA, »Frauenschaft «, "SS« eller »HitlerJugend «, deltage i noget, som foranstaltes af Dansk Skoleforening, må de f.eks. lære dansk, gå med til gymnastik eller husflid.

Jeg vil personligt skelne imellem, om vedkommende går over til nazismen af overbevisning eller nødtvunget. Er det af den første grund, kan man ikke vare dansk, men er det af den sidste, kan en forbindelse med danskheden bevares.

Selve arbejdet har ellers gået sin gang $\mathrm{i}$ det forløbne år ...Helhedsindtrykket er: Det går, men noget trykket.»

(Niels Kjems, Harreslev marts 1934)

Ladelund: »Arbejdet er som helhed gået støt. Arets store begivenhed for os i Ladelund har rejsningen af forsamlingshuset været. Grundstenen hertil nedlagdes den 23. marts 1934 af gamle maler Nikolaj Johannsen, Ladelund. Ved nedlæggelsen udtalte han ønsket om, at der mellem husets mure måtte blive virket for dansk sprog og kultur og for sønderjysk skik.

Forsamlingshusets rejsning afhjælper et længe følt savn og stiller nye opgaver.

(Ladelund 23. marts 1934. Gustav Lindstrøm). ${ }^{60}$

"Den forste storm har lagt sig, og den første glans er falmet. Enkelte, der blev blandet og gled, søger at vinde fodfæste for at arbejde sig tilbage. Det har været lettere for den danske vandrelærer at færdes $i$ vinter, end det var sidste vinter.« (Deltagelsen også lidt større end 1933-34) (Niels Kjems marts 1935). 
Ladelund: "Som helhed er arbejdet i 1934-35 gået meget tilfredsstillende. Det har vist sig, at dette, at der nu er et fast sted at samles herude, har styrket de trofaste. Måske også ydre forhold har virket her; men tilslutningen til danske foranstaltninger er i hvert fald større, end vi kunne vente.

Udsigterne for dansk kulturelt arbejde $\mathrm{i}$ Kær herred er for tiden så gode, som de ikke har været siden 1922. Derimod er mulighederne for de danske unge, der nu vokser op og søger uddannelse og erhverv, meget få.« (Ladelund 31. marts 1935, Gustav Lindstrøm). ${ }^{61}$

\begin{abstract}
Vandrelærerne:
nDet må allerførst fastslås, at regeringens tvangsforanstaltninger over for ungdommen stadig er en hindring for det danske mindretals frie udfoldelse. Ikke nok med, at dansk ungdom stadig tvinges $i$ en arbejdslejr, hvor målet er: »En nationalsocialistisk sjæl $i$ et sundt legeme«; de må ikke læse den danske avis, de må ikke mødes med deres familie i de danske forsamlingshuse; nej, de tvinges allerede fra 15-års alderen at mode $\mathrm{i}$ tvangs-efterskole, så vidt jeg ved tre timer ugentlig i tre vintre. Vi kan vel ikke regne med, at ånden $\mathrm{i}$ disse tvangsefterskoler er mere frisindet end $\mathrm{i}$ arbejdslejrene.« (Niels Kjems 1936) ${ }^{62}$
\end{abstract}

Det forhold, at det danske mindretal blev tolereret, hindrede dog ikke ganske problemer og chikaner, hverken over for skolebørn eller unge. Indførelse af varnepligten og den indoktrinerende nazistiske arbejdstjeneste i 1935 var en klar belastning, her blev de unge dansksindede isoleret udsat for et stærkt gruppepres. Sekretær Fr. Petersen formulerede det på et møde i Haderslev den 27. februar 1936 således: "I det folkelige arbejde og i ungdomsarbejdet lægges der ikke danskerne nævneværdige hindringer i vejen, men derimod fyldes vi af bekymring over, at danske unge i Sydslesvig nu drages ind $\mathrm{i}$ de tyske arbejdslejre og kaserner. Formålet $\mathrm{i}$ disse lejre er jo at opdrage disse unge til gode nazister. Det er denne tvangsnazificering og tvangsfortyskning af vor ungdom, vi har nedlagt protest imod. ${ }^{63}$

Trods det stigende nazistiske pres og den voksende militarisering af samfundet oplevede man fortsat også bidske danske reaktioner, der ikke altid blev taget lige nådigt op af magthaverne. En af de unge, der protesterede, var Franz A. Julius fra Flensborg. Nogle undgik i tide Arbeitsdienst og militærtjeneste ved at få dansk statsborgerskab. Franz A. Julius besluttede, vist nok som en af de første, at desertere, da han fik sine indkaldelsespapirer. Han ville muligvis kæmpe for en kejser Wilhelm, men ikke for Hitler, og måtte holde sig skjult $\mathrm{i}$ Danmark $1940-45 .^{64}$

Lige op til krigens begyndelse lykkedes det at holde nær forbindelse 
til Nordslesvig, også til Det unge Grænseværns store stævner. Gennem lektor Aage Rosenkjær holdt man kontakt med organisationen, der 1935-36 også optrådte i Sydslesvig, også dette område var en meningsfyldt del af det spraglede vandrelærerarbejde. ${ }^{65}$ Der kunne være mange formalia og bureaukratiske besværligheder, tyske toldere var et kapitel for sig. Den blinde antisemitisme førte til personlig kontrol af personalier, arierparagraffen skulle følges. ${ }^{66}$ Men efter at have berettet om diskriminering og chikaner kunne sekretær Fr. Petersen på et møde nord for grænsen i marts 1936 dog berette om en mere humoristisk episode fra Ladelund: "... En mængde tyskere mødte op med orkester og søgte at ødelægge mødet. Der opstod en sangerkrig. Under pausen gik værten ud og sagde til tyskerne: $\mathrm{Nu}$ skal vi have kaffe. Kom ind og få en tår med, for I må jo også være blevet tørre i halsen. Da listede tyskerne slukørede hjem. ${ }^{67}$

Der kunne også være problemer i egne rækker, således da friserlederen Johs. Oldsen i en periode flittigt intrigerede mod Fr. Petersen og min far og ønskede en frisisk forening $\mathrm{i}$ konkurrence med det danske arbejde og Slesvigsk Forening. ${ }^{68}$

\section{Skolen i Ladelund}

Efter forsamlingshuset, som det havde været ganske svært at få på benene af rent økonomiske grunde, kom turen til en skole. Oprettelsen af skolen i Tønning blev i den tyske presse opfattet som en krigserklæring. Denne opfattelse styrkedes af Svend Johannsens skarpe ord ved indvielsen: "... Vil tyskerne endelig have grænsen flyttet, kan der kun være tale om at flytte den derhen, hvor den rettelig hører hjemme. ${ }^{69}$

Fra nazistisk side gennemførtes en intens overvågning af mindretallet i Tønning, der ikke opfattedes som »ægte« dansk, men som samlingssted for politisk hjemløse elementer. Stigningen i de danske skolers elevtal 1933-36 blev fra tysk side begrundet med »de marxistiske familier«, og der blev fra tysk side bevidst lagt stærkt pres på familierne, som det var svært at stå imod. Det lykkedes med nød og næppe at få ti børn til skolestart i Kirkevang. Indvielsen af skolen fandt sted 12. december 1936. Ved selve skolestarten nogle dage før for de 10 børn havde min far budt dem og den nye lærer Chr. Stenz velkommen og bl.a. udtrykt ønsket om, "... at der i skolen måtte arbejdes ikke for had og uvilje mod alt det fremmede, men med kærlighed til det hjemlige og til Danmark ... «Og den 28. august 1938 kunne en egentlig skolebygning indvies ved siden af Kirkevang, der samme år fik elektrisk lys. ${ }^{70}$ 


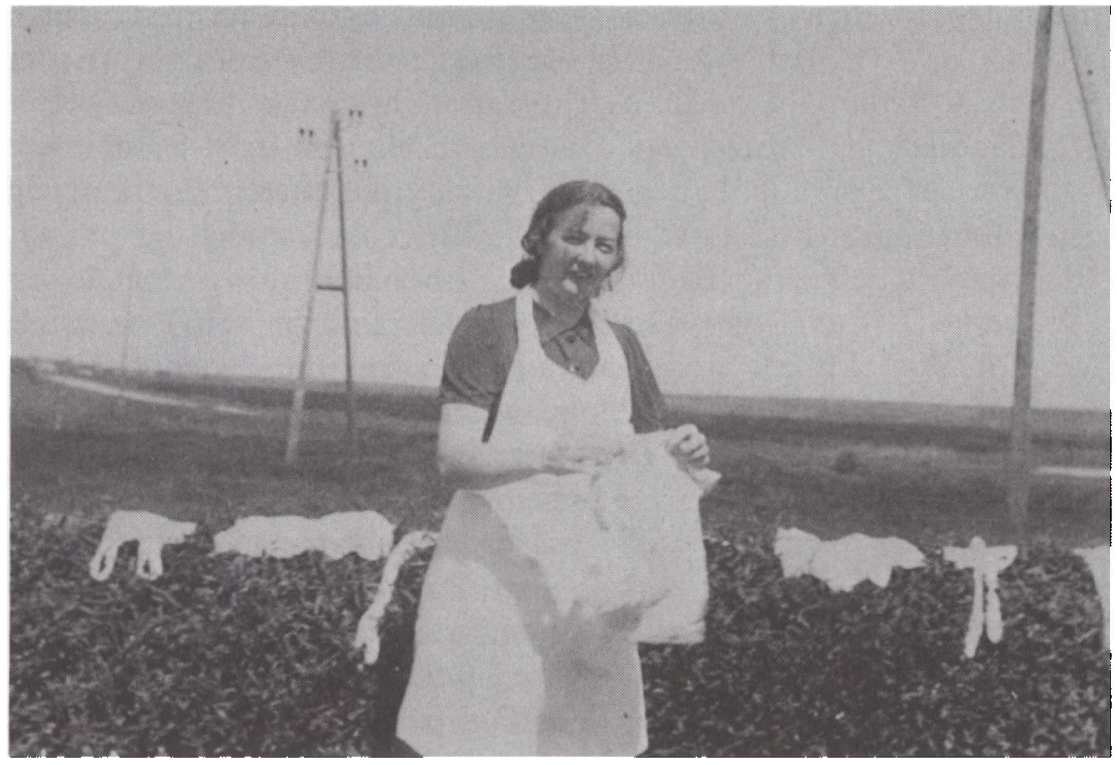

Da det trak op til krig, blev mine foraldre gift. I dag er Ladelundomrddet blevet andret, og landbruget starkt moderniseret som folge af egnsudviklingsprojektet Program Nord fra 1953. Pa billedet ser man heder og moser.

Billedet er fra sommeren 1939 og viser $i$ ovrigt min mor Anna, $f$. Andersen, der er gårdmandsdatter fra Vilslev ved Ribe. (Privateje)

Men der var også meget andet end det almindelige vandrelærerarbejde. Da ritmester H. M. Lunding begyndte at opbygge et meddelernet syd for grænsen til sin efterretningsvirksomhed, ville han have min far med; men det kunne de ikke blive enige om.

I sommeren 1939 oprettede Dansk Skoleforening med støtte fra DUG et vandrehjem i Kirkevang. ${ }^{71}$

\section{Krigen kommer}

Med den brune revolution var der tilsyneladende blevet skabt arbejde. Sidst $i$ trediverne var arbejdsløsheden stort set forsvundet. Men det kunne ikke skjules, at en stor del af den økonomiske genrejsning skyldtes den målbevidste nazistiske genoprustningspolitik.

Denne politik betød meget for kystregionen Slesvig-Holsten og dens betydelige skibsværftsindustri, der havde lidt katastrofalt under verdenskrisen. Kiel blev krigshavn, hvad der nok førte til økonomisk 
fremgang, men også medførte risiko for luftbombardement i tilfælde af krig. Andre byer i Sydslesvig og Holsten fik ligeledes status som militære støttepunkter, og der blev anlagt omfattende militære vejsystemer, depoter og kaserner og hvad der ellers skulle til af militære installationer. Som i efterkrigstiden virkede de store militære anlæg med tilhørende garnisoner som en form for egnsudviklingshjælp. Områder, der i særlig grad blev præget af oprustningsprogrammet, var f.eks. øerne Sild og Helgoland, men også Østersøhavne som Flensborg, Egernførde og Lübeck nød godt af den nazistiske flådeopbygning. Flensborgs skibsværft blev en blomstrende krigsindustri.

Min far havde ikke mange illusioner om nazismens væsen og Hitlers hensigter. Allerede fra 1937 var krigsforberedelserne og militærpropagandaen blevet mere iøjnefaldende. Der blev arrangeret luftforsvarsøvelser og flydemonstrationer også i Sydslesvig. ${ }^{22}$ Fra sommeren 1938 begynder han i sin dagbog at skrive om krigsfrygten. Krigsfrygten var også baggrunden for, at mine forældre giftede sig allerede i marts 1939, få måneder før Hitler-Tysklands overfald på Polen i september 1939.

"Krigen kom, som vi længe havde ventet. Allerede et godt stykke tid inden var rationering indført på forskellige varer, og vore unge og senere også de gifte mænd måtte af sted på den tunge gang. Jeg husker, hvor det skar mig i hjertet, da vor nabo drog af, og hans to små drenge stod i vinduet og råbte "Far!« så længe de kunne se ham. Det lykkedes at holde forbindelsen med mange af de danske sydslesvigere gennem hele krigen, indtil de faldt, blev væk eller kom i krigsfangelejr.

Der kom mange feltpostbreve, næsten alle på dansk, også fra dem, der ikke havde gået i dansk skole. De var rolige i tonen, men åndede en stille hjemlængsel. Men også glæden ved tanken om det, vi havde haft sammen i de danske foreninger.

Der var galgenhumor $\mathrm{i}$ nogle, og kras lune $\mathrm{i}$ andre breve. Hentydninger, som censuren ikke fik fat på, - som når en skrev: "Jeg er tæt på, hvor Christian Petersen bor.« Hans ejendom i Ladelund kaldes Krim! Der var ivrige spørgsmål om, hvorledes forholdene var i Danmark, som ikke var så lette at svare på, da det var begrænset, hvad vi vidste bag den lukkede grænse, og hvad vi kunne risikere at skrive.» (Det blev i løbet af krigen stadig vanskeligere at få lov til at passere den dansk-tyske grænse).

"Der kom breve med påskriften "Adresse ubekendt" eller "Gefallen für Grossdeutschland «. I alt faldt der af dem, som var kommet til sammenkomster i Ladelund, 8 mand, og lige så mange var savnede, deraf 3 gifte med børn. Vi savner dem alle, også flinke tyske naboer, 

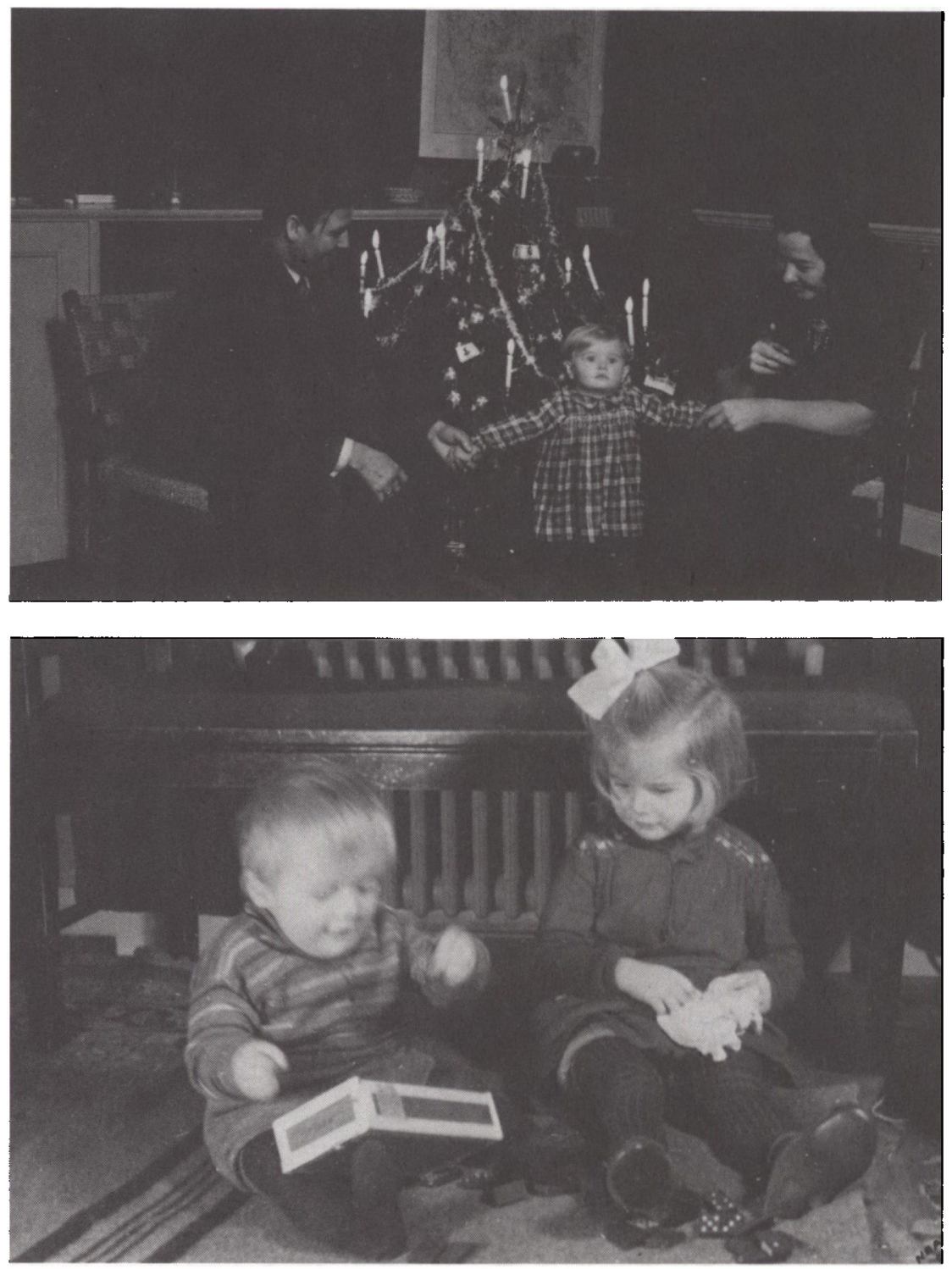

Både under og lige efter krigen levede vi meget spartansk, men led da i hvert fald aldrig direkte ned. Vi gik i brugt tøj, men $i$ modsatning til mange andre syd for gransen kom vi aldrig til at sulte.

Det overste billede viser min soster Gunhild, da hun lidt over et \&r gammel var til sit forste juletra 1941.

Det andet billede er fra ca. 1945 og forestiller os begge. Der var jo ikke meget legetoj at få, så man måtte improvisere sig lidt frem. (Privateje) 
der blev derude, mindes vi med vemod, « skrev min far mange år efter $i$ en erindringsskitse.

De mange breve fra indkaldte sydslesvigere var som næunt gennemgående skrevet på dansk, også selv om de ikke havde haft egentlig danskundervisning. Men bedst gik det for dem, der havde været på skole- og ferieophold i Danmark. De havde både på den ene og den anden måde mere at stå imod med ...

Den 26. august 1939 begyndte Hitlers Wehrmacht at indkalde soldater til krigen mod Polen. Ladelund mærkede krigsudbruddet dels ved, at indkaldelser fandt sted, dels ved, at den lokale nazistiske Arbeitsdienstlejr, oprettet i 1938, afleverede sin arbejdskraft til militæret. Arbeitsdienstfolkene havde ellers været beskæftiget med vejarbejde og læplantning. ${ }^{73}$ Pastor H. F. Petersen har beskrevet krigsudbruddet således: "Så skulle vi da til at opleve en anden krig, værre end den første. Nogen begejstring sporede vi ikke. Sårene fra den første verdenskrig var endnu ikke lægte. Sulten og nederlaget fra sidst kunne endnu huskes, og det nazistiske styre var mere frygtet end elsket. Mange af vore unge var allerede indkaldt, nogle af dem allerede året i forvejen. For dem alle var det kun pligtens vej - uden glæde og håb. ${ }^{74}$ Men for tyskerne betød felttoget i Polen en vældig psykologisk opstramning. I Flensborg-området mærkedes krigens virkninger mere krast. Der faldt under Polenfelttoget mange soldater rekrutteret fra Flensborg og omegn. ${ }^{75}$

Allerede den første krigsvinter mærkedes forsyningsproblmer. Rationerne holdt rimeligt, men der var stærk mangel på brændsel i den kolde vinter. ${ }^{76}$

Den daværende lærer ved skolen i Ladelund, Chr. Stenz, har i en kronik skrevet om, hvordan man i Ladelund oplevede den 9. april. Han selv kom tilbage over grænsen den 8. april 1940. Han slap for en gangs skyld lempeligt over den dansk-tyske grænse ved Sæd, hvor tyskerne ellers de sidste syv måneder havde gennemført en usædvanlig nidkær kontrol: "Klareringen hos tyskerne var for en gang skyld forholdsvis lempelig. Ellers havde de sidste syv måneders kropsvisitation fra top til tå været reglen.

Bortset fra indstilingen hos chefen selv var det vist nok ikke ond vilje fra toldernes side, men efter krigsudbruddet var grænsetrafikken så lille, at enhver passage blev betragtet som en kærkommen afbrydelse i den daglige ørkesløse kedsomhed. Derfor trak de tiden ud.«

Mine forældre var den 9. april i Danmark og nåede først hjem nogle dage senere; men allerede den 14. april blev der holdt gudstjeneste i 
det danske forsamlinghus, gudstjenesten var som også under resten af verdenskrigen en nyttig anledning for medlemmerne af det spæde danske mindretal til at udveksle oplysninger om den aktuelle udvikling. Chr. Stenz skriver i slutningen af sin kronik: "Lørdag aften kom min gamle ven Niels Christensen på uventet besøg. Han var ikke nået over grænsen den 8. april og kunne nu fortælle nogle enkeltheder $\mathrm{i}$ og omkring besættelsen. Niels blev modtaget med åbne arme, og sjældent har vi, min kone og jeg, lyttet mere hengivent til hans beretninger fra Danmark. Gennem sin far, landstingsmand Jefsen Christensen, havde han muligheder for at få en ekstra god orientering.

Kirkegængernes antal var det største, jeg endnu havde oplevet her. Efter gudstjenesten kunne jeg videregive Niels' informationer - eller en del af dem - og de er nok blevet påhørt med mindst lige så megen opmærksomhed som skriftens ord. Vor lille danske kreds var levende optaget af, hvad der angik Danmark og delte dets skæbne på godt og ondt. $^{77}$

For dem, der havde frygtet en tysk besættelse nord for grænsen, var det måske en lettelse, at frygten blev afløst af vished den 9. april. Syd for grænsen blev den nazistiske virkelighed endnu mere knugende. Gestapo markerede stilfærdigt sin årvågenhed kort efter besættelsen. Den danske skoleleder i Slesvig Svend Johannsen blev arresteret for sin kritik af nazismen. Han blev efter flere måneders fængselsophold sendt til koncentrationslejren Sachsenhausen, hvor han fik lov at sidde ca. 12 måneder. ${ }^{78}$

Det var lykkedes det danske mindretals ledelse at holde mindretallet frit af det ellers næsten altomfattende nazistiske organisationsapparat; men mindretallets unge slap ikke for den halvmilitære uddannelse $\mathbf{i}$ Arbeitsdienst, hvor anderledestænkende blev udsat både for nazistiske indoktrineringsforsøg og for grov chikane. ${ }^{79}$ Ligeledes var det så godt som en selvfølge, at de danske sydslesvigere skulle gøre tysk militærtjeneste, ganske uanset om de havde lyst. Det lykkedes enkelte sydslesvigere at unddrage sig militærtjeneste. Mod krigens slutning lykkedes det flere, deriblandt den helt unge Karl Otto Meyer, at undvige. Til det sidste var det en yderst risikabel affære at flygte fra nazistisk militærtjeneste, det kunne koste livet. Nazistisk militærjustits var allerede fra 1943 usædvanlig streng. ${ }^{80}$

"Modsat de mange nordslesvigere, som under den første verdenskrig gik over grænsen, var det kun få sydslesvigere, der vovede at blive $\mathrm{i}$ Danmark, når de fik ordre til at møde ved den tyske værnemagt« ... "Der var flere grunde til, at de danske sydslesvigere trods stor ulyst 
trak i den tyske trøje: De vidste, hvor godt kontrollen med dem var organiseret, og de var bange for, at udeblivelse ville medføre repressalier mod deres hjem, og endelig, at det efter besættelsen ville være meget svært at skjule sig i Danmark eller komme videre til andre lande.

Jeg traf i Nordslesvig en aften tilfældigt sammen med en ung sydslesviger, som jeg kendte godt. Han gik nu under et andet navn, og skønt det var gode danske folk, der var til stede, fik jeg af værten strengt påbud om, at jeg ikke kendte den unge mand og helst ikke skulle tale med ham. - For ham lykkedes det ved gode venners hjælp at holde sig i Danmark under hele krigen. ${ }^{81}$

"Men de fleste af vore unge måtte $\mathrm{i}$ krig for en sag, der var dem inderligt imod. Endnu tungere blev det for de danske sydslesvigere, at de efter rekruttiden blev spredt ud over Europa sammen med folk

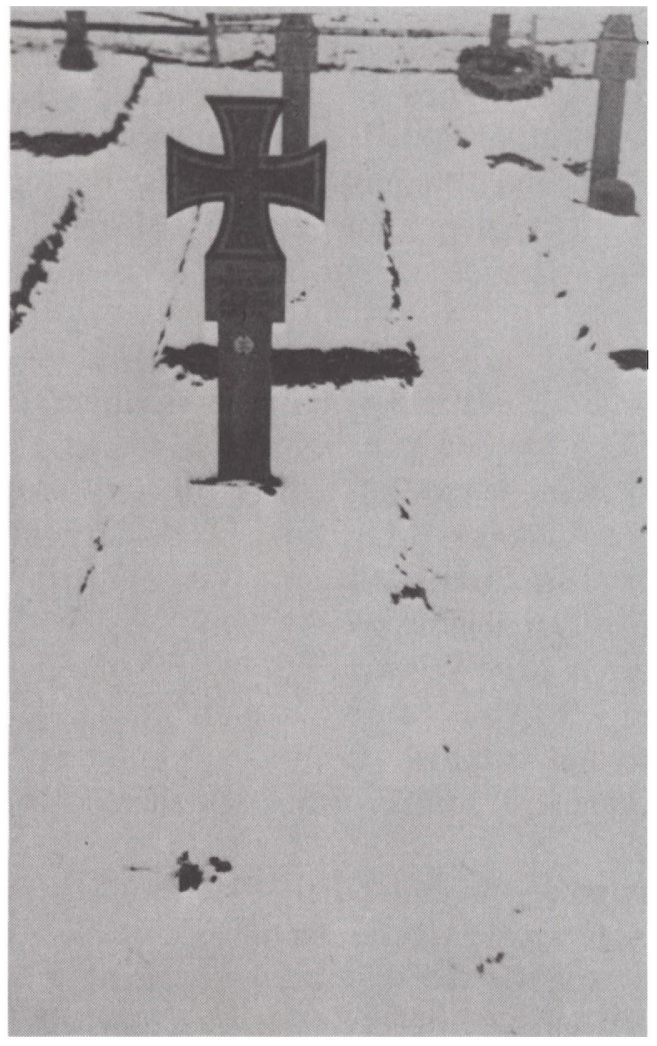

Det slog utrolig hdrdt at miste de unge danske sydslesvigere, der blev tvunget $i$ krig 1939-45. Fa turde eller kunne unddrage sig den nazistiske arbejdstjeneste og den efterfolgende militare tjenestetid. Peter Lund fra Medelby faldt $i$ forsommeren 1940 under Frankrigsfelttoget, han var en af de forste af min fars elever, der faldt. Her ses hans grav $i$ Frankrig. (Privateje) 
fra alle egne af Tyskland og kun sjældent kom sammen med andre sydslesvigere. De fleste af vore unge tog dog fattede af sted. For en af de unge, der først kom hjem fra Danmark efter indtrængende opfordringer, var det dog så svært at drage af sted, at han bogstavelig måtte skubbes ud af sit hjem.

Kun enkelte var så heldige at komme til Danmark efter den 9. april. En af dem skriver: »I går marcherede vi op til vor øvelsesplads, og vi kom gennem en gade, hvor der var hejst det ene danske flag ved det andet. Da tænkte jeg: Hvis jeg nu ikke var blandt alle disse soldater, så var jeg jo hjemme her. Alle disse flag mindede mig om mit hjem, hvor det samme flag står i stuen, og om vort forsamlingshus i Ladelund."

De fleste onskede dog ikke at komme til Danmark. De gruede ligefrem for at vise sig der $\mathrm{i}$ tysk uniform. I denne nød trøstede de unge sig med det tilsyneladende selvmodsigende, at det var Danmarks sag, de gik ud at kæmpe for. Når de gjorde deres pligt som tyske statsborgere, havde de efter krigen ret til at være i deres hjemstavn som medlemmer af det danske mindretal og kunne derigennem også støtte Danmark.

Stærkt møder vi dette syn i Marius Andersens omtale af sin ven Peter Lunds død. De to var som en undtagelse sammen, indtil Peter Lund faldt ved Crony i Frankrig juni 1940 og udåndede i sin kammerats arme. Marius skrev: "Selv om jeg er langt fra hjemmet, tænker jeg meget på jer. En sørgelig meddelelse må jeg give jer. Døden har taget Peter Lund ud af vore rækker. Han faldt $i$ et stormangreb over for den fjendtlige maskingeværild. - Hans sidste ord var, at jeg skulle hilse alle derhjemme, og at Danmark måtte leve i sin fulde frihed. Lad os håbe, at dette offer ej er forgæves, men at han må mindes og tjene for retten i vor hjemstavn. ${ }^{82}$ Marius Andersen faldt i Rusland i 1942.

Tabene i dræbte, sårede og savnede slog meget hårdt på det talmæssigt spinkle mindretal, der også geografisk var spredt. Allerede i 1942 var den 51. af mindretallets værnepligtige faldet. ${ }^{83}$

Hitler-Tyskland var tæt på at vinde krigen. Tættere på, end vi i dag bryder os om at tænke på. "Der herskede hos de unge sydslesvigske krigsdeltagere $\mathrm{i}$ de første krigsår en overbevisning om, at den tyske krigsmaskine var så effektiv og uovervindelig, at de tyske sejre ville vedvare, til alle modstandere var nedkæmpet (og det måtte deres indhøstede militære erfaringer på de forskellige fronter i første omgang også næsten nødvendigvis underbygge). Men nogle kunne også se, at derfor ville der ikke være fred i verden.«

... "Der kom en dag, da det var en vinding at blive såret, når det 
ikke var for alvorligt. Ja, selv Peter (Peter Andresen, Agtrup), der under kampene på Krim mistede den ene hånd og fod, da han reddede en såret tysk kammerat ud af ildlinien, kan give udtryk for sin glæde over, at han beholdt livet. Men der lyser også en barsk humor ikke ulig den, man møder hos mændene $\mathrm{i}$ de islandske sagaer, når han skriver fra lazarettet: "Mange tak for brevet, som jeg fik i går. Nu har jeg rigtig tid til at læse breve. Dog har jeg nu begyndt at øve mig til vintersporten 1943, jeg har nemlig anskaffet mig en stok, og så hopper jeg løs. Jeg har bragt det så langt, at jeg selv kan gå ud $\mathrm{i}$ haven og ind igen, hvad der er meget værd. Mere bliver det heller ikke til, inden jeg har mine kunstige lemmer ... Det glæder mig, at sporten og folkedansen trods alt bliver holdt $\mathbf{i}$ gang derhjemme. Jeg kommer bagefter og ser, hvad de unge kan. ${ }^{84}$

Peter Andresen var meget medtaget, da han kom hjem til Agtrup. Det hed i et brev til Hans Lund i Rødding den 19. november 1942: "Peter Andresen besøgte os i søndags. Det var strengt at se ham, men det spores, at han både har vilje og kræfter til trods alt at få noget ud af livet .... $\ll^{83}$

"Som tiden gik, og den tyske værnemagt blev trængt tilbage, begyndte vore sydslesvigere at kunne se, hvor det bar henad. Livet blev hårdere, og de trængte til at få luft for deres følelser. Det var begrænset, hvad de turde skrive af hensyn til censuren. Dog kom der ikke så lidt igennem, særlig fra dem, som mestrede ironien, og noget kunne man læse mellem linierne. ${ }^{86}$

Der var mange nuancer i soldaterbrevene, der glimtvis afslørede den barske dagligdag og krigens gru. Hans Ditlev Andresen, en anden af brødrene Andresen, var den mest markante brevskriver. Det følgende er nogle eksempler på hans krasse stil:

(Til familien Lindstrøm

Travemümde 4.6.1940) "... Hvor er det godt, at I stadig kan holde møder og derigennem vise, om også hele det danske folk lever under et vist tysk tryk, I på ingen måde føler jer nedtrykt og slået. Bare det stadig vil blive sådan. Men når enhver dansk kun bliver fædrelandet tro, må Danmark da holde sig. -

Jeg vil ønske, at I må få et rigtigt godt årsmøde og derigennem vise tyskerne, at det danske mindretal endnu er der. - Besøg fra Danmark er vel ikke muligt dette år; men igennem pressen må de da vel kunne læse om den danske stilling syd for grænsen ...« ${ }^{87}$ 
(Pillau 16.2.1941)

»... Og fremtiden? - Jeg ved kun så lidt. Men én ting er vi vel klar over, at den hårdeste krig endnu vil komme. Hvordan den vil ende, ved vel ingen. Dog en gang må fremtiden da stå os åben. Gid det så også må stå godt for vor danske sag.

Jeg ved kun så lidt at skrive, og $\mathrm{i}$ grunden ved I meget mere som jeg. Desuden tror jeg, vore tanker passer godt sammen, så noget længere skriveri derom behøves ikke.

Men jeg beder jer om, spar ikke ved at skrive. Det er så meget værd, thi vi trænger til at føle, at den danske frihed endnu lever.

Hvor er det en sølle opfattelse af frihed tyske unge har ... $\ll^{88}$

Da Hitlers hære angreb Jugoslavien og Grækenland den 6. april 1941, skrev Hans Ditlev Andresen hjem til Ladelund fra sit opholdssted i Pillau:

"... Tiden er hård og ventetiden usigelig lang, og er der lyse udsigter. I dag slås der igen på en ny krigsskueplads. Hver gang må der lides og dræbes. Men fred tales der nu så grumme lidt om. Ville det enkelte menneskes tanker bare blive skreget ud, jeg tror, det ville blive et eneste skrig om fred. Men endnu lader folk sig jo overtale. Dog endnu er overraskelsernes tid jo ikke forbi. Amerikas og Japans holdninger er jo klarlagt, og på en vis måde er de jo allerede med i krigen. Men Ruslands holdning er måske endnu det store spørgsmål ....

"... Jeg har altid været spændt på, hvad der stod i mine personalpapirer, og da jeg jo ligger sammen med en her på stuen, som til daglig roder $\mathrm{i}$ de sager, og jeg forstår mig helt godt med ham, har jeg fortalt ham om min danskhed. - Han siger, der står intet. Men han forstår godt, at der gives andre mennesker $i$ Tyskland end lige bare NS ... $\ll^{81}$

Den 17. april 1941 kapitulerede Jugoslavien, den 21. april 1941 fulgte Grækenlands overgivelse. Den 22. juni 1941 startede det nazistiske korstog mod Sovjetunionen, men på trods af den første lynkrigs forbløffende sejre var begejstringen ikke udelt på hjemmefronten. Veteraner fra Rusland 1914-18 huskede udmærket. Hitlers hære måtte standse foran Moskva og opleve en frygtelig vinter. Også næste forår stod de uden afgørelse midt i Rusland. Hans Ditlev Andresen sendte den 21. marts 1942 denne stemningsberetning hjem fra Pillau. Han skrev bl.a.: "... Men tiden går jo, snart står vi lige så stolte som vore fædre, snart kan vi bryste os med, at vi også stod fire år i trøjen - også mod en stor overmagt. Ja, vi begynder nu også at blive de gamle, seje 
soldater, som vandt, idet de tabte. Jeg begynder nu den 1. april mit fjerde år. Den ære har man vundet - tabe noget gør da ingen i det stortyske rige. Det er da en stor sejr, når man f.eks. har fået mennesker så vidt, at de er tilfredse med 4 stykker brød, hvor man før - uden at bruge det - fik så meget man ville have ..."

»... Man hører jo frygtelige meddelelser fra fronten, og det er vel ikke nemt at stå støt $\mathrm{i}$ troen og håbet der. Men når jeg skal gå her $\mathrm{i}$ Pillau, har jeg taget mig som formål ikke at lade mig underkue af denne grimme krig, uforstandige, tyranniske mennesker er skyld i ... $\ll^{91}$

Sommeren 1942 bragte store nye tyske sejre både i Afrika og Rusland, hvor tyske tropper nåede Kaukasus. Men de tyske tab voksede. Samtidig mærkedes de første psykologiske følger af luftkrigen. Det var især store byer som Kiel, Neumünster og Lübeck, der mærkede noget til de store luftbombardementer, selv om Flensborg ikke slap helt. Det første luftangreb på Kiel fandt sted den 2. juni 1940. Det kostede 9 dræbte og 25 sårede. I løbet af krigen blev store dele af Kiel ødelagt. 97 angreb dræbte ca. 3000 mennesker, 7290 blev såret, ca. $165.000 \mathrm{blev}$ hjemløse. RAF påbegyndte i foråret 1942 systematiske storangreb på de tyske byer. Lübeck var ude for det første svære angreb natten 28.-29. marts 1942. Propaganda var ikke nok til at imødegå dette svære chok, civilbefolkningen fik nu respekt for luftalarmer og bombeangreb. Befolkningens evne til at tåle de psykiske og fysiske belastninger, som krigen påtvang, var blevet svækket. I Lübeck oprettedes en særdomstol til at pådømme alvorlige forbrydelser, derunder sortbørsslagtning. Dommene kom til at lyde på dødsstraf eller langvarige frihedsstraffe. Til skræk og advarsel blev de annonceret $i$ alle blade. ${ }^{91}$

Krigens tab gjorde hastigt alvorlige indhug i de danske sydslesvigeres rækker. Det var bittert at være i uniform for så dårlig en sag som nazismen. Hans Ditlev Andresen skrev den 24. juni 1942 fra Pillau:

"... Ja, I har tilstrækkeligt lært sørgebudskabene om vore faldne at kende. Det er rigtignok en elendighed; når man hører om de svære tab og man så tænker, at man jo også selv endnu understøtter krigen, så kan man rigtignok komme til at spørge sig selv, om man ikke er med til at støtte noget, man $\mathrm{i}$ hele sit levned vil have at huske på. $\mathrm{Nu}$, hvor vi allerede har tre års krig, vil det vel heller ikke blive anderledes. Os blev noget taget, som vi vel aldrig får tilbage. - Bare med denne krig vi så også virkelig havde ende på denne elendighed, men hvad kan vi tro nutidens sig $\mathrm{i}$ angst vridende pralhalse. $-\mathrm{Og}$ dog håber jeg. Hvorfor ved jeg næsten ikke, men når håbet er tabt, er man da selv fortabt.

Fra Peter [hans bror, der var ved fronten i Rusland] har vi jo da 
endnu temmelig ofte forholdsvis godt nyt. Han er nu nok rigtig med dernede. Men han kan da have heldet med sig. - Her i Pillau er ellers alt ved det gamle. Hvor længe vi endnu er her er tidens spørgsmål. Vi har jo kun at vente, men det har man jo lært $\mathrm{i}$ løbet af årene.

Jeg håber, at I har heldet med jer ved valget af den nye præst. En god præst er helt sikkert meget værd i denne tid ...«. ${ }^{92}$ Det var han. Det blev Martin Nørgaard, der selv var vokset op i Sydslesvig og derfor talte både sønderjysk og tysk, der kom til at efterfølge Waage Beck som præst $\mathrm{i}$ landdistrikterne. Waage Beck blev med kort varsel udvist af Gestapo i 1942, fordi han havde kritiseret nazisternes behandling af jøderne. Martin Nørgaard startede sin præstegerning på såre beskedne vilkår. Landdistrikternes menigheder kendte han ikke meget til endnu, de materielle kår var meget beskedne. Men en cykel fik han forærende af en kreds af borgere i Gråsten, og han gik så i gang med pr. cykel at betjene de 9 sydslesvigske menigheder fra Aventoft og Ladelund til Tønning. Via faste lærere og vandrelærere fik han opbygget sig et kendskab til de folk, han nu skulle betjene.

For sydslesvigerne var menighedens sammenkomster og gudstjenester åndehuller i en ellers temmelig glædesløs hverdag, ud over Guds ord fik man også af og til lidt aktuel baggrundsinformation, og i et nazistisk samfund, der ellers var gennemsyret af politiovervågning og stikkeri, kunne man på disse snævre lukkede møder tale frit. Kirkeligt set var de sydslesvigske distrikter en blandet landhandel. Den kirkelige interesse varierede meget, nogle steder på landet stødte man på den hedenske og antisemitiske Ludendorff-bevægelse, og overtroen trivedes stadigt i tilbagestående landdistrikter. Præsten var en af de få, der gennem sit arbejde virkelig kom meget rundt i det meste af Sydslesvig og talte med forholdsvis mange. Han var derfor også velorienteret om folkestemningen og om krigens faktiske virkninger. Der kom hver dag meldinger om faldne, sårede og dem, der var kommet i krigsfangenskab. Postbudet blev sorgens budbringer, folk ventede ængsteligt på postens triste budskaber. Det værste var at se de helt unge blive sendt i krig. Sidst på krigen blev næsten alle, unge og gamle indkaldt. Konfirmanderne græd, da de måtte af sted. De gamle, der ikke kom til fronten, blev indkaldt til militærtjeneste i den lokale Volkssturm.

Den lokale befolkning fik i øvrigt også sporadisk en del at vide om, hvad der foregik i de besatte områder og ved fronterne. Mange ønskede ikke at vide for meget, nogle frygtede at erfare for meget; men gradvis sivede adskillige oplysninger bl.a. om jødernes og krigsfangernes skæbne tilbage til det tyske samfund. En del fik lokalbefolkningen at vide 
gennem frontsoldater på orlov. Behandlingen af krigsfanger og tvangsdeporteret arbejdskraft kunne den ved selvsyn dømme om. ${ }^{93}$ Især de østeuropæiske fanger blev behandlet dårligt, i overensstemmelse med den nazistiske ideologi. Østeuropæerne fik prygl som straf og måtte ikke fraternisere med befolkningen. Harmløse overtrædelser af forskrifterne straffedes undertiden med døden. Efter krigen hævnede fangerne til forbløffelse og forskrækkelse for tyskerne sig. ${ }^{94}$

Hans Ditlev Andresen nåede i sommeren hjem til sit bryllup, men måtte hurtigt tilbage til sit tjenestested i Pillau. Den 13.9.1942 skrev han herfra tilbage til Kirkevang, hvor han havde holdt bryllup med Hedvig: "... Nu er alt jo anderledes, og det går for mig videre på den lange krigs-bane. Dog jeg holder den ud. - I holder så vel en mindefest for Marius Andersen. Igen kan vi sørge over en af vore venner, og nu skriver Hedvig mig i dag, at Marius Mikkelsen også er faldet. Det er forfærdeligt; man kommer ligefrem til at tænke sig om. - Hvor kan man så endnu snakke om held. Vi besøgte Peter, og vi var alle meget glade for den dag, vi var sammen. Trods Peters store ulykke, som han selv godt er klar over, kan hans glæde over, at han må leve videre opveje alt hos ham.« (Peter var blevet invalideret ved den russiske front.) $)^{95}$

Hans Ditlev Andresen fik hurtigt andet at tænke på. Den 19. november 1942 sendte han denne hilsen til Ladelund: "... Ja, det kom hurtigt anderledes for mig. Tiden her er nu snart forbi. Også dette levned har vi vænnet os til. Ligeledes vil fronten vel blive vores daglige ledsager. - Jeg går i den tro til fronten, at det nok skal gå. En gang må det da være slut, og hvem ved, hvor længe det vil vare. - De sidste nyheder fra Afrika og Frankrig (de allierede gik i land i Nordafrika i november 1942) er da vel nok et nyt afsnit i denne krig. Om de bliver uden følger, ved man ikke. Jeg tror det næppe.

Jeg læste i et blad, at Danmark igen har en ny regering (Scavenius). Er det noget godt? Jeg tror det ikke. Dog vi håber på en god fremtid og tror, at vi altid må blive og være de samme danske som vi er det nu. Vort danske mindretal må ikke lide noget nederlag. Jeg tror ikke derpå.

Lindstrøm, jeg beder dig hilse derovre i Danmark. Jeg beder jer at hilse vennerne derhjemme ....1.96

Efter nederlaget ved Stalingrad i slutningen af januar 1943 begyndte det at gå hurtigere tilbage for nazisterne. Goebbels bebudede den totale krig den 18. februar 1943. Trods de dårlige brevforbindelser lykkedes det at holde en sporadisk kontakt med de unge sydslesvigere ved 
østfronten og andre steder. Det danske mindretals unge håb forblødte støt. Hans Ditlev havde været heldig, han var blevet såret, men kommet godt fra det. Den 24. marts 1943 skrev han denne hilsen: "... Ja, I kan tro, jeg er glad for at være ude af denne elendighed. Her har jeg det meget godt, og alt får man efterset her. Mine sår er hele, og jeg har heller ikke beholdt nogle splinter i hovedet. Men nu har jeg jo gigtfeber, og dette har igen forårsaget hjerte-svaghed, så der kan måske endnu gå en lille tid, hvor jeg skal være her. Dog det er jo også kun det rigtige, thi kun når man er fuldkommen rask, kan man tage del $\mathrm{i}$ den totale krig. Nu man er kommet herind i en varm seng, hævner sig alle de kolde nætter derude i jordhullet, de uendelige tilbagemarcher, hvor man ved hvert »Holdt « segnede om på den isblanke kørebane og sov som en sten. - Jo, krigen gør os stærke! Men nu, når alle de unge og friblevne kræfter træder an, og kvinderne har overtaget hjemmefronten, skal vi jo nok holde de uendelige russiske reserver op. Mon man 1941 har vidst, at Rusland var så stærkt og stort? - I dag kan man næsten tro, at de ikke vidste det. -

I kan tro, jeg har kun et ønske, og det er dette, at de folk, som endnu agiterer for krigen, selv må komme ud og opleve den. De behøvede kun at komme ud og møde fronten den første dag, som vi gjorde det en kold december-dag. Vi mødte en flok infanterister, som havde en halmstak som kvarter. De sad omkring et jernrør, som var deres ovn og kogte kaffe af sne, som de smeltede. Langskæggede, skidne madrester $\mathrm{i}$ skægget, pjaltede og livløse af træthed, næsten ikke til at få svar ud af -.

Et stykke videre hen stod et par, som forsøgte at bekæmpe lusene. - Det er den sejrende tyske soldat i vinterkrigen i Rusland. - 14 dage senere var vi selv de samme stakler. Om Rusland kunne jeg fortælle meget, men ikke pr. brev. - Et har jeg fået med derudefra, og det er et usigeligt had til alt, som vil krig og tjener krigens formål. Mange tyske kammerater går det ikke spor bedre ... $\ll^{97}$

Sydslesvig og Holsten slap bortset fra de største byer og militærbaser som Kiel, Neumünster og Lübeck i de første krigsår nådigt fra luftkrigen. Flensborg med marineinstallationer og skibsværft udgjorde et attraktivt mål for allierede flyvere. Byen mistede i løbet af hele krigen ca. 2700 indbyggere, deraf kun 176 dræbte under bombeangreb. I alt 41 bombetogter havde sigte på Flensborg. Det værste luftangreb kom den 19. maj 1943. Det gik her ud over industrikvarteret og skibsværftet. 83 personer blev dræbt, den danske børnehave og flere danske lærerboliger blev ramt og 15 børnehavebørn og flere voksne mistede livet. 
Krigens sidste bombardement af Flensborg en af de allersidste krigsdage $\mathrm{i} 1945$ kostede mange flygtningebørn livet. ${ }^{98}$

Det nazistiske felttog i de østeuropæiske lande var usædvanligt grusomt, det var til dels en ideologisk motiveret udryddelseskrig. Gestapo, SD og de forskellige dele af SS førte an i det brune korstog, også Waffen SS, forstærket med mange tusind frivillige fra de besatte europæiske lande, var kraftigt engageret i destruktionen af de europæiske jøder, zigeunere og andre folkeslag. Dele af den tyske Wehrmacht deltog fuldt på linje med SS etc. i myrderierne, andre dele af det tyske militær distancerede sig klart fra den nazistiske udryddelsespolitik, men da var det for sent.

For de soldater, der gjorde tjeneste i Rusland, Jugoslavien eller andre østeuropæiske områder, var det svært slet ikke at erfare noget. En del af de unge sydslesvigere fortalte også, når de var på orlov, en hel del bl.a. om massakrer på jøder og krigsfanger og om den brutale behandling af civilbefolkningen i de erobrede områder. Enkelte kunne ikke bære belastningen, den frygtelige vished om forbrydelserne, og tog deres eget liv. Men både den militære disciplin og politistatens overvågning var streng og fuld af farer for åbenmundede. Var der noget, der prægede folk, så var det frygten. De fleste, næsten alle - var frygtelig angst for at vide noget, fortæller Martin Nørgård. Sidst på krigen kom det i øvrigt også til opgør mellem den helt unge tyske generation og den gamle - deres forældre, der havde satset på Hitler og havde sendt dem i krig.

Der var som sagt mange nuancer og forskelle $\mathrm{i}$ det billede, den enkelte kunne danne sig af krigens udvikling og forholdene $i$ andre lande. Visse informationer sivede tilbage til slægt og venner fra soldaterbreve. Soldaterbreve blev ofte censureret, der var mundtlige oplysninger fra soldater indlagt på lokale krigsfangelazaretter, og dem blev der efterhånden mange af. Tillige var der flygtige kontaktmuligheder til deporterede tvangsarbejdere og til krigsfanger. En sjælden gang blev sandheden sagt ganske åbent. ${ }^{99}$ Juli 1943 havde været præget af svær tilbagegang for de nazistiske våben. I Kursk var de tyske reserver på østfronten blevet slidt op i et kæmpemæssigt kampvognsslag, Sicilien var ved at blev erobret. Bombardementerne af Hamborg den 24. juli - 3. august 1943 gjorde et særligt indtryk. Ved de storstilede bombeangreb omkom mange tusind mennesker i flammerne. 600.000 flygtede fra byen, og mange blev indkvarteret i Sydslesvig og Holsten. Theo Christiansen fortæller fra Slesvig, at rædselsberetningerne fra Hamborg 
trængte ind $\mathrm{i}$ hvert eneste hjem. Efterlysninger efter savnede sås slået op på plakatsøjler og tavler.

Mange flygtninge medbragte $\mathrm{i}$ deres kufferter makabre minder, de sammenskrumpede fosforlig af slægtninge og bekendte. ${ }^{100}$

Nazisterne havde ikke lagt skjul på deres had til jøderne. Der var ikke mange jøder i Sydslesvig og Holsten, før krigen knap 4800; men antisemitismen florerede alligevel, og som i resten af Europa blev jøderne bortset fra de heldige få, der nåede at flygte, udryddet. I dag lever kun et par hundrede jøder i Slesvig-Holsten, spredte minder i form af synagogebygningen i Rendsborg, der bruges som røgeri, samt forskellige andre bygninger og kirkegårde er det eneste, der vidner om jødisk kultur $\mathrm{i}$ de tidligere hertugdømmer. ${ }^{101}$

Hans Ditlev Andresen havde oplevet de sidste tyske nederlag på østfronten og hørte om ødelæggelsen af Hamborg. Den 12. august 1943 sendte han dette korte-ironisk-sarkastiske brev, hvor han bl.a. skrev: "... Jeg har i dag begyndt hjerte-kuren (han var stadig medtaget efter at være blevet såret). - Nu håber jeg, den virker sig godt ud, thi med mit helbred er det det samme trods mandeloperation m.v. Men skulle jeg ikke blive helt rask igen, så kan jeg da også prale af på tærskelen til det femte krigsår, at jeg har opnået noget.

$\mathrm{Ja}$, den store tid, vi lever $\mathrm{i}$, går videre. Man forstår bare ikke, at de store ikke holder ud med den af dem særprægede store tid. - De allierede er da nogle forfærdelige magter. Men Fæstningen Europa er jo uantastelig - hvad gør tabet af næsten hele Sicilien? Vi kan kun leve videre $\mathrm{i}$ troen på vor store sejr.

I Hamborg må det jo se forfærdeligt ud. - Ja, hvem havde troet, at vi i selve Tyskland skulle have de samme massegrave, som de af jøder fyldte i Polen og Rusland og andre lande? - Krigen er da den største synd! Forhåbentlig har den »anden verdenskrig" lært menneskeheden det mere! «102

Sommer og efterår 1943 var præget af dystre indtryk og dystre meldinger. Store bombemaskineformationer overfløj Sydslesvig og Holsten undervejs til raketforsøgsområdet Peenemünde og andre østtyske bombemål, og selv om det fortsat mest var de store byer fra Hamborg til Kiel, der var udsatte, måtte man også i Sydslesvig mere ned i kældre og luftbeskyttelsesrum. Bitre efterretninger om faldne, sårede og savnede ved fronterne indtraf $i$ stigende omfang. Samtidig mærkedes rationeringen af levnedsmidler og tøj stærkere.

For Hitlers Tyskland betød det stigende antal svære nederlag på de 
forskellige krigsskuepladser en intensiveret agitation til mobilisering af masserne. Blandt frontsoldater og revalidender agiterede nazisterne for, at de skulle melde sig frivilligt til SS, faldskærmssoldater eller andre såkaldte eliteenheder. Mange gav efter for det stærke pres, andre afviste med foragt hvervningsforsøget og opfattede det som absurd teater, at soldater, der oplevede deres femte krigsår i live, skulle risikere det ved nu at melde sig. ${ }^{103}$

Invasionen i juni 1944 og attentatet 20. juli 1944 på Hitler antydede sammen med de vigende fronter i øst, hvilken vej det gik. I Sydslesvig blev en række tidligere SPD-folk arresteret og sat $i$ koncentrationslejr i forbindelse med det fejlslagne attentat. Adskillige danske sydslesvigere oplevede den allierede landgang i Frankrig på nærmeste hold. Det gjorde således den senere journalist ved Flensborg Avis, Karl Christiansen, der tilbragte de følgende år i amerikansk fangenskab. Lærer Dinsen Hansen fra skolen i Ladelund var også i Frankrig og var noget utilfreds med den voldsomme militære aktivitet.

Dinsen Hansen skrev den 30. juli 1944 dette brev fra Frankrig.

Kære Familie Lindstrøm.

Alt længe var det umuligt at sende jer en hilsen. På grund af de urolige forhold med alarm både dag og nat er jeg bleven noget forsinket med mit arbejde, så den udvidede korrespondence har måttet hvile. Af et brev fra min søster fra i går ser jeg, at I er i Ladelund. I tænker måske ikke på at rejse nordpå. Jeg håber, at I må få gode ferieuger, hvad enten I er i Ladelund eller i Danmark. ... Vi har det forholdsvis roligt nu i den sidste uge. Har nok haft alarm, men ingen angreb. Den foregående uge var vel nok slem. Som de har huseret her! Det er et sørgeligt syn at vandre gennem byen. Heldigvis har den bydel, vi grænser op til - vi er flyttet ind $i$ byens periferi - været heldig. Her er kun faldet enkelte brand- og sprængbomber. Vi har tabt en garage ved ildebrand efter et angreb - en stor garage til en lille snes biler, men er glad for, at det ellers gik så godt af.

Hvad mener man ellers om krigssituationen i Ladelund, Karlum og Vestre? Mon det ikke nu lakke mod enden? Kan det vare år endnu, inden én af parterne er kørt træt eller fuldstændig knust? Jeg kan ikke tro det. - Jeg længes meget efter mit civile tøj, kan I tro. Og så har jeg det jo godt endda $\mathrm{i}$ forhold til så mange andre. ${ }^{104}$

Turen mod katastrofen gik stadig hurtigere. I august 1944 nærmede russerne sig den østpreussiske grænse, den 25. august rykke de Gaulle ind i Paris, den 11. september 1944 stod allierede tropper ved det tyske riges vestgrænse mellem Trier og Aachen. Hitler-Tysklands sidste reserver fra alle befolkningslag blev nu mobiliseret. Udnyttelsen af 
koncentrationslejrfanger og slavearbejdere nåede et uhørt omfang, de tyskere, der virkede på "hjemmefronten«, måtte op på en 60-timers arbejdsuge, mens rationerne blev fattigere og fattigere. Med oprettelsen af den tyske Volkssturm omfattende alle 16-60 årige mænd, forberedtes et sidste forsvar. Østtyske flygtninge begyndte at strømme til fra de store områder, Hitlers vigende styrker måtte opgive ved østfronten. Der var mangel på alt, og nok led civilbefolkningen, men det var intet imod det, tvangsarbejdere, krigsfanger og koncentrationslejrfanger blev udsat for. ${ }^{105}$

Befolkningen i Sydslesvig og Holsten havde nok sporadisk hørt om koncentrationslejre før. Nogle vidste en hel del om dem, mange var i hvert fald bange for at komme i dem. Nu fik folk i Ladelund og i Husum-området den nazistiske virkelighed præsenteret. Som led i de hektiske bestræbelser, der blev udfoldet for at styrke forsvaret af HitlerTysklands rester blev der startet befæstningsarbejder i Sydslesvig. Arbejdskraften blev bl.a. leveret fra den store koncentrationslejr Neuengamme ved Hamborg.

Ladelund kendte som Husum til krigsfanger og tvangsarbejdere. I november 1944 kom omkring 2000 mand vandrende fra jernbanestationen i Agtrup til den arbejdslejr, der havde plads til 200 mand. Det var fanger fra KZ Neuengamme. Neuengamme havde ca. 40 arbejdskommandoer, lejre, hvor KZ-fangerne var udstationeret til slavearbejde. Svesing ved Husum fik et lignende antal. I begge KZ-arbejdskommandoer skulle fangerne grave pansergrave til den sidste kamp for HitlerTyskland. Begge udstationeringer blev en katastrofe for de tusinder af fanger, der blev berørt. Lejrene var opløst inden jul 1944, men da var adskillige hundrede fanger allerede døde. Mange død af sult, sygdom og udmattelse, andre en voldelig død.

Arbejdets karakter medførte, at både civilbefolkningen i Husumområdet og Ladelund fik lejlighed til at iagttage fangernes elendighed. Civilbefolkningens reaktioner var meget forskellige, der var mange nuancer i den lokale befolknings forståelse af KZ-fangernes situation. Nogle mente, at det var forbrydere, der blot med rette fik en hård straf. Andre så med forfærdelse på det, der skete, når fangerne vandrede ud med madkasserne og om aftenen hjem bærende på deres døde. De kom ofte tæt på huse og gårde, men ingen kunne hjælpe dem. Pansergravsarbejdet blev gennemført et par hundrede meter fra det danske forsamlingshus Kirkevang i Ladelund. Min far har i en erindringsskitse givet et indtryk af forholdene i Ladelund: 
»Med gru så danske som tyske fangerne vakle ud til arbejdet, hvor de blev mishandlet. Der var altid nogle, som blev båret hjem af fire kammerater, og i de 5 uger, lejren var her, blev over 300 af dem jordet i massegrave på Ladelund kirkegård.

Hvad havde disse folk forbrudt? - Ja, fra byen Putten i Sydholland var alle mandlige indbyggere mellem 16 og 60 år kommet $i$ koncentrationslejr, fordi to tyske officerer var blevet skudt der. Det var ikke bevist, hvem der havde skudt dem.

Fangerne gravede pansergrave og kom derved ofte nær til huse og gårde, men ingen kunne hjælpe dem. En mand, ved hvis hus de arbejdede, udtalte, at skulle dette fortsætte, måtte han køre sin kone til Slesvig sindssygeanstalt. En kone $\mathrm{i}$ Ladelund sagde til mig med tårer i øjnene: "Jeg skammer mig ved at være en tysker.«

Vi havde 28 vagtmænd indkvarteret. Det var gamle marinesoldater, og de var imod den behandling, fangerne fik. En af de første dage, de var her, sad en af dem, en tysk skuespiller, i vor stue og græd og sagde: "Hvordan skal det gå mit tyske folk, sådan som vi behandler fangerne?« Han var et fint og sympatisk menneske, men prøvede dog at forsvare oprettelsen af lejrene med, at det var englænderne, som $\mathrm{i}$ boerkrigen havde begyndt med koncentrationslejre. Blot et enkelt eksempel på, hvad vi måtte opleve og ingenting kunne gøre ved: Jeg skulle ud på marken $\mathrm{i}$ et ærinde på en gård og mødte så en flok, der kom hjem $i$ sivende regn der i november måned. Noget af det første, jeg mødte, var fire mænd, der bar en mand, som jeg ikke kunne se på, om han var hel- eller halvdød. $\mathrm{Og}$ ved siden af stod deres bødler, Kapos, kammeratskabspolitiet, som de kaldtes. Det var rene forbrydere. De stod der med nogle svære læderhandsker og slog ham i ansigtet, mens de fire stod og bar ham. Og den tyske vagtmand stod ved siden af og græd, så tårerne løb ned ad kinderne på ham. Men han måtte ingenting gøre.

Lidt længere henne mødte jeg igen et optog. Der lå en fange på knæ med foldede hænder, og en tysk soldat slog ham $\mathrm{i}$ hovedet med kolben. ${ }^{100}$

Martin Nørgaard, der arbejdede som »cykelpræst « i landdistrikterne fra Lyksborg til Ladelund, Aventoft og Tønning, fik set sit af koncentrationslejrenes rædsler i Ladelund og Husum. Han har bekræftet oplysningerne om den forfærdelse, der registreredes i den lokale befolkning, da man fik de grusomme realiteter at se. Nørgaard kom selv ud for et brutalt politiforhør mod slutningen af krigen og kom i klemme, da han havde været med til at hjælpe en ung sydslesviger over grænsen. ${ }^{107}$

Hans Ditlev Andresen opholdt sig fjernt fra Danmark og fra Sydslesvig. Mens de fleste nord for grænsen, selv i Tønder fă $\mathrm{km}$ fra Ladelund intet vidste om, hvad der skete i Ladelund, men nok lidt om Husum, fik han gennem slægt og venner den nødvendige baggrundsviden om KZ-arbejdskommandoet, da han havde været på et kort orlovs- 
besøg hjemme. Få måneder tidligere var han åbent begyndt at skrive om krigsforbryderne, der snart måtte stå til regnskab. Den 10. december 1944 skrev han fra Nellingen bl.a.: ").. Særlig hørte man jo opsigtsvækkende fortællinger om forholdene hos jer i Ladelund. - Som mennesker da kan være grimme mon hinanden - men det er at anerkende, at der også er andre, der er modige nok til at henvise til den store synd under de øjeblikkelige forhold. Nå, når I har haft vagtfolkene, ved I sikkert ikke så lidt ..." Han berettede om det stærke pres, der fra nazistisk side blev udøvet for at indoktrinere de indkaldte og ikke bare gøre dem til gode soldater, men til gode nazistiske soldater. ${ }^{108}$ Ikke mindst de grønne 16-årige rekrutter blev presset stærkt, så Waffen SS kunne blive styrket. Især sidst på krigen lykkedes det adskillige, deriblandt Karl Otto Meyer, at desertere, men det indebar en betydelig risiko. Alene ved Wehrmachts officielle krigsretsapparat blev der fældet 16.000 dødsdomme og henrettet ca. 10.000 mand desertører, foruden de talrige, der med det samme blev gjort kort proces med, og desertørerne udsatte ikke blot sig selv, men også deres familie for en egentlig risiko. ${ }^{109}$

Videre hedder det $\mathrm{i}$ brevet $» . .$. her ligger vi stadig $\mathrm{i}$ beredskab. Alarm har vi så småt hele dagen. Fronten buldrer ved dag og ved nat. - Men vi er alligevel glade for, at vi har denne bestilling. For en tid siden regnede vi stærkt med, at vi skred af til infanteri eller SS. « Han oplyste, at han havde henvendt sig til det danske generalsekretariat i Flensborg og fået dokumentation på, at han tilhørte det danske mindretal: "thi jeg vil selvfølgelig gøre alt imod at blive politisk soldat. « ${ }^{110}$

Den 26. januar 1945 sendte Hans Ditlev Andresen det sidste soldaterbrev fra østfronten, hvor sammenbruddet nærmede sig. Store flygtningemasser søgte at trænge vestpå, væk fra den sovjetiske hær, der nu hævnede de forbrydelser, der var blevet begået i Østeuropa. Der var store tab både blandt militære og civile. Det hedder i brevet »... Ja, der er sikkert blevet skrevet meget ved indgangen til det nye år. Stemmerne har sikkert ikke været tvetydige, det kan de jo slet ikke være; dog derpå er jeg sikker, at det vil give hårde tider for de fleste af os.

Det nye år har jo allerede sit særpræg. Offensiven i øst er jo ligefrem sensationel. Jeg var i Obserschlesien for en uge siden. Flygtninge, navnlig kvinder og børn og mange sårede fra fronten strømmede mod vest. Alle ville med. Togene var overfyldte. Kulden gjorde sin del til det kaos. Børnene skreg, kvinderne med. Til dels grænsede det op til panik. - Ja, man kan virkelig sige, at det tyske folk præsterer meget ... Dog, når det først er såvidt, som det er i øst, mærker man intet 
mere til den store "Solidaritet«. Men jeg tvivler ikke på, at disse mennesker da stadigvæk stoler på den store fører.

Vi skal jo flytte i nærmeste fremtid; dog alle vil gerne blive her - og vi er glade for hver dag, der går. Pommern, hvor vi skal komme hen, er jo allerede frontnær.

Her er det vinter med masser af sne. Man bliver helst inden døre, hvis man kan. Ellers kørte sporvognene jo hele dagen ud, hvor vi bor, men nu da alle fabrikker har lukket, kører de ikke.

Tog- og postforbindelser er jo også minimale. Jo, det er Tyskland i dag. Det kan være, det er det bedste tegn for, at krigen snart er forbi .... $\ll^{111}$

De sidste krigsårs dagligdag var prægede af meget trange kår. Min far skrev i et brev nordpå midt $i$ januar 1945 "... vort arbejde har indtil nu gået uhindret, da skolestuen har været fri, men ellers bliver alt hver dag tungere for de danske hjem ... « Forsyningssituationen blev gradvist mere kritisk, rationeringen blev skrappere. De, der kunne, søgte at skabe små nødlagre, så de havde noget at falde tilbage på, hvis krigshandlingerne nåede Sydslesvig. Politiovervågningen blev skærpet.

"Vi, der kunne blive hjemme, søgte at holde skole og moder i gang, og det gik. I 1943 var børneskolen i Ladelund nede pà et antal af 6 børn, men i 1944 steg tallet til 11. Til møderne lykkedes det et par gange at få en taler ned fra Danmark. Så var der højtid. Ellers klarede vi møderne med hjemlige kræfter, og vi spillede endda dilettant. Da der kun var store drenge tilbage hjemme, måtte de unge piger $\mathrm{i}$ mandfolketøj, og så prøvede vi på at live hinanden op, mens vi ventede på nazismens sammenbrud. Da værnemagten i 1940 rendte det meste af Europa over ende, kneb det, men da englænderne gennemforte hjemfarten fra Dunquerque, fik vi nyt mod, der ikke siden helt forlod os.

Vore danske gudstjenester blev til trøst og oplivelse for os. Vor prast Waage Beck blev udvist (i 1942), men pastor Martin Nørgaard fik lov at komme herned i stedet. Han kom engang om måneden. De danske præster havde meget at varetage. Efter gudstjenesterne, som altid var godt besøgt, drak vi en kop kornkaffe, og så gik snakken frit om krigen og forholdene herhjemme, og det var ikke for nazi- eller gestapooren, hvad der blev sagt. Men aldrig blev noget robet. Vor kreds var fast.

Der kom mange fanger til egnen (der kom seks millioner deporterede til Hitler-Tyskland foruden millioner af krigsfanger). De havde det gennemgående godt og sultede ikke. Ringest havde polakkerne det, men det hævnede sig også nogle steder efter kapitulationen i 1945.

En skønne dag fik vi også indkvartering af fanger i Kirkevangs sal (der også var kirkesal). Det skete under protest, men hjalp ikke, og vi har ikke fra tysk side făet en pfennig i erstatning, skønt der skete store skader på huset. Vi havde en 30-40 mand ad gangen, og det var russere og polakker, 
hollendere og belgiere, tyske soldater og til sidst i 1945 de såkaldte "Blitzmädel«, indkaldte piger, der var at beklage, men som var nogle frakke tingester. Fangerne var mest unge mand, der var hentet om natten eller indfanget $\mathrm{i}$ deres hjemland, når de kom hjem fra kirke eller biograf, og sendt på tvangsarbejde i Tyskland. Nogle kom fra lejre fra Hamborg, hvor de ikke havde haft det godt. Her klarede de sig. På en undtagelse nær var deres vagtmænd flinke. Kålrabisuppen, som blev kørt hertil, lugtede ganske vist, så naboens gris ikke engang ville have den; men de stjal eller fik kartoflerne hos bønderne her, og min kone kogte så kartofler, tit fra om morgenen og til kl. 23. Hun havde kun et kogested på et lille nødkomfur, vi havde, da vort elkomfur ikke måtte bruges. Om søndagen fik de flæaskebidder $i$, og når de kunne fă noget salt til, var de godt tilfredse. Var en af fangerne dårlig, fik han lov at blive hjemme." Nazistiske elementer $\mathrm{i}$ den lokale befolkning behandlede især polakker og russere dårligere end de andre fanger. Således nægtede en læge fra Sønder Logum at behandle en polsk fange, der havde blindtarmsbetændelse.

Som minde om fangerne i Kirkevang har vi endnu en takkeadresse forfattet af de hollandske og belgiske fanger. Nogle af fangerne kom i øvrigt til at spille en nyttig rolle i dagene omkring det tyske sammenbrud og kapitulationen maj 1945. ${ }^{112}$

„Fangerne var gennemgående renlige, men da det kneb med sæbe, og den fugtige halm, de lå $i$, ikke blev udskiftet, var det en slem stank, der slog ud af nøglehul og sprækker $i$ døren ind til salen, så det gialdt om at få gangdøren op i en fart om morgenen. Vore børn på to og fire år gik trygt imellem fangerne, og skønt (som en særlig venlighed mod lærerfruen) de, der havde lus og fnat, var indkvarteret $i$ børneskolens garage, fik ingen af børnene smitten. (113 $^{113}$

Det nazistiske system lignede sig selv $i$ al sin umenneskelighed lige til det sidste, tusinder af koncentrationslejrfanger gik til i krigens sidste dage, under dødsmarcher eller på overfyldte skibstransporter, der blev sænket under krigshandlinger. Så sent som den 2. maj 1945 blev der kæmpet under den britiske overgang i Lauenburg, mens Hamborg blev erklæret for åben by. Det var uvist, om der skulle kæmpes i Sydslesvig og Holsten eller Danmark og Norge, hvor der endnu stod store intakte troppestyrker. ${ }^{114}$

"Endelig kom den 5. maj 1945.

Det så truende ud her som i Jylland. I dagene forr havde tyske soldater gravet dybe maskingeværreder $\mathrm{i}$ læplantningen ved Kirkevang.

Vi kunne ikke høre radio, da vi kun havde strøm nogle få minutter hver dag, og da skulle vi pumpe vand. Jeg kørte ud til en gård på marken, hvor man havde anodebatteri, og jeg fik hørt noget af statsminister Buhls tale. Så var der ikke mere strøm i batteriet.

Senere hørte jeg, at to byer i Danmark var blevet bombet, og jeg 
troede, at det var Ribe og Logumkloster. I retning af dem havde jeg set lysskær.

$\mathrm{Nu}$ ventede vi på vore danske unge, at de skulle komme hjem fra fronterne. Et par af dem kom for tidligt. De havde varet nede ved Elben og set, at der var fare for at falde i russernes hænder. Så havde de snuppet hver en cykel og var rask kørt det par hundrede kilometer hjem til mor. Men de fleste måtte forst i fangenskab, og for dem, der kom i russisk fangenskab, blev det en lang og trang tid før de genså hjemmet.

Den 8. maj fik jeg bud med en frihedskæmper, om jeg ville komme til Tonder til seminarieforstander Morten Bredsdorff og hjælpe med fordeling af madvarer til danske syd for grænsen.

Jeg cyklede til Sæd, hvor den tyske tolders kone stod bønfaldende med foldede hænder og skreg: »Ach, lieber Herr Lehrer, können Sie nicht mein Mann helfen? Er hat doch gar nichts getan!« - Det havde jeg ingen lyst til. Han havde i én uge sørget for, at jeg blev klædt af til skindet på en ganske grundløs mistanke, så han kunne have godt af et lille ophold hos englanderne. Han kom også snart fri.

Og jeg havde nok med at klare mig selv, da en tysk officer mellem hjemdragende soldater optrådte temmelig truende. Men et par frihedskæmpere, der kom til, hjalp mig igennem, så jeg kom ud til Bredsdorff og fik aftalt det fornødne. Tillige fik jeg en engelsk sergent, som var gæst hos Bredsdorf, til at køre mig ned over grænsen.

Da englænderen satte mig af, kom en tysk gårdejer, jeg kendte, farende og spurgte, om jeg ikke kunne hjælpe ham hos englænderne, så han kunne beholde sit jagtgevær. Det kunne jeg ikke hjælpe ham med.«

Dagene omkring kapitulationen var i det hele taget meget urolige. Det kom til skudepisoder nord for grænsen mellem SS og frihedskæmpere. Det hændte, at tyske soldater på vej hjem fra Danmark måtte aflevere deres våben til englænderne, fordi de begyndte at bruge dem mod hinanden. ${ }^{15}$ Kapitulationsdagene blev ikke mindre sindsoprivende syd for grænsen, i Agtrup, Karlum og Ladelund.

I Agtrup blev nogle unge tyske socialdemokrater, deriblandt agteparret Piper vistnok fra Kiel, i sidste øjeblik likvideret af lokale nazister, fordi de en kende for tidligt var begyndt at fejre Nazi-Tysklands sammenbrud. 116

Fanatiske nazister i militæret såvel som i den lokale civilbefolkning opretholdt indtil fem minutter efter tolv ønsket om at kæmpe videre, og den nazistiske propagandamaskine gjorde sit til at holde myten om en stærk underjordisk militærorganisation af varulve i live, varulve, der skulle bekæmpe de allierede besættelsesstyrker. ${ }^{117}$

Egteparret Jens og Kirstine Hansen fra Karlum havde hverken før eller under krigen skjult deres klare danske sindelag. Ved krigens slutning blev der af nazisterne i Sydtønder amt lagt op til et sidste 


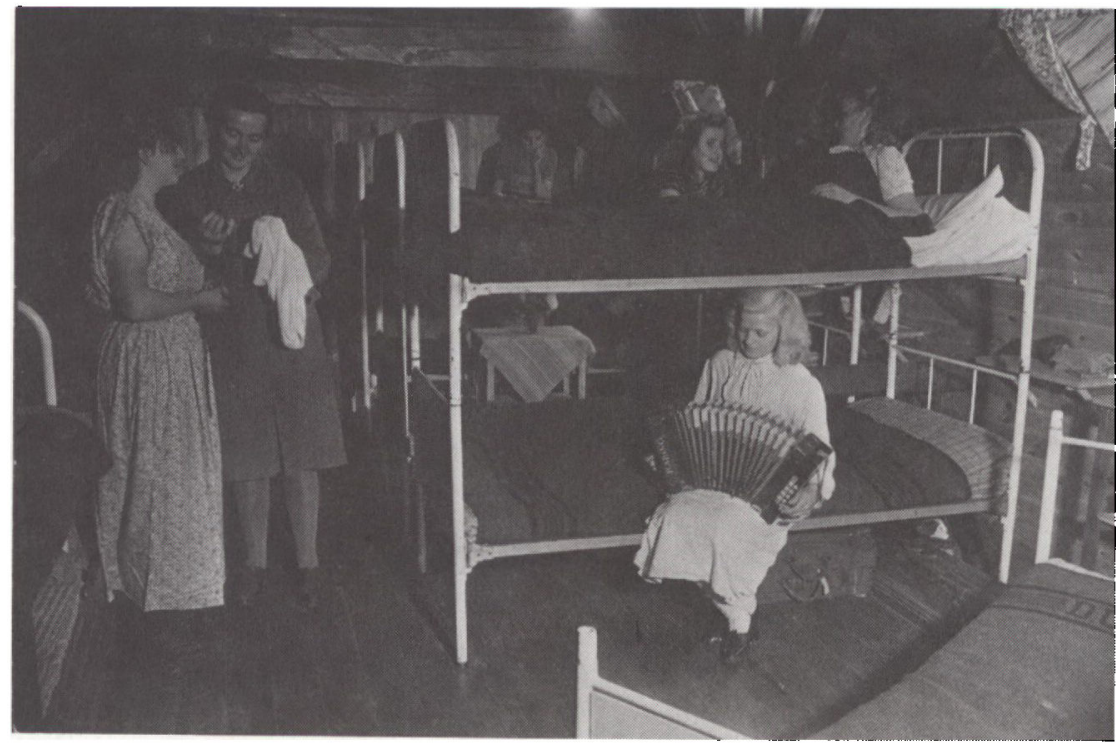

Den forste sprog-og ungdomsskole i Ladelund fra 1947 måtte isar $i$ starten arbejde under overordentlig primitive forhold. Bortset fra, at eleverne skulle lare noget og stifte et spagfardigt eller mere varigt bekendtskab med dansk og danske forhold, var det nok ikke det varste, at de fik tag over hovedet og noget at spise hver dag. Det var ikke så let at sikre dem en rimelig ernaring, for de forste efterkrigsair i Sydslesvig og Holsten var fulde af nod og elendighed, både for flyg tninge og hjemmehorende. Person $\mathrm{nr} .2$ fra venstre er min mor, resten elever $i$ deres spartanske sove- og opholdsrum. Til daglig var idyllen nok sd sparsom. (Privateje)

opgør. Med varulves hjælp forberedte lokale nazister likvideringen af den ene af sønnerne, Andreas Hansen (i dag skoleinspektør i Rendsborg). Andreas Hansen var vendt hjem med den ene arm svært beskadiget, skønt krigsinvalid var han stadig i uniform. Broderen Karsten var endnu ikke komme hjem. Desuden søgte nazisterne at provokere Jens Hansen, krigsveteran fra første verdenskrig, hvilket var nær ved at lykkes.

Det var nazistiske tropper, der var ved at forlade dansk område, der skulle til at gennemføre dette stykke likvidationsarbejde. Britiske besættelsesstyrker, netop ankommet til Sydslesvig, nåede at gribe ind i sidste øjeblik, efter at dele af familien Jens Hansen var flygtet til Ladelund. Fra forsamlingshuset Kirkevang blev der med fanger sendt bud til de fåtallige britiske styrker på Læk flyveplads, der omsider satte en stopper for den nazistiske aktion. Sommeren 1946 skildrede Andreas 
Hansens søster Tinne under et ophold på Rødding højskole den dramatiske episode $i$ en fristil: "Nogle oplevelser fra dagene efter NaziTysklands kapitulation.«

„Et par dage efter Tysklands kapitulation fik vi en indkvartering af tyske soldater, som kom fra Danmark. Kl. 9 om aftenen kom den ene panzer og motorcykel efter den anden oppe ved vejen og svingede ned til os. $\mathrm{Vi}$ kunne ikke forstå, hvad de ville os; men det viste sig snart, at de allesammen skulle indkvarteres. De var blevet sendt af borgmesteren, som længe havde haft et godt øje til os. Der var ikke mindre end mellem 75-80 mand, vi måtte stille alle 3 lader til rådighed. Nu omringede de hele vor ejendom med deres køretøj, halmstakken blev brugt til at dække dem til med, som om de tankte på at blive en længere tid. I skoven lå der nogle hundreder, ligeledes med deres køretøjer.

Min bror, som havde orlov fra lazarettet, var den forste, der faldt dem i kløerne. Han havde sit Danebrog på trøjen, det kunne de jo ikke tåle at se. Det blev til en længere diskussion, og det var ikke pæne ting, der blev sagt, om hvad han mente, min bror var i hans øjne. Det viste sig snart, at det var SS folk, og at alle endnu bar våben. De ville ikke overgive sig, men slå sig igennem til den anden side Hamborg.

Glad for deres selskab var vi ikke, der blev ikke til meget søvn den nat. Hele huset blev omsat med dobbeltvagtposter, vi blev forbudt at gå til eller fra huset for om morgenen.

Vi kom hurtigt $i$ forbindelse med englænderne gennem en af vores polske fanger, som vi var gode venner med. Naste dag kom han med et par englændere på motorcykel, og disse forlangte, at inden kl. 4 om eftermiddagen skulle tyskerne aflægge deres våben. Det lovede de naturligvis; men gjorde det ikke. Næste dag gik, uden at der skete noget særligt, udover at de skød omkring huset og i skoven. Lange kunne de nu ikke holde husfred. Om aftenen ville løjtnanten gerne have et værelse, hvor han kunne afgøre nogle vigtige forhandlinger med et par mere. De mente endnu, at det var dem, der bestemte. Han fik lov til at benytte stuen, Danebrogsflaget, som stod, fjernede han, så han ikke havde det lige for øjnene. Så begyndte de at snapse til langt ud på natten. Mine forældre sov lige ved siden af og kunne ikke undgå at høre, hvad der blev sagt derinde. De var blevet fulde og højrøstede, og så kommer sandheden for dagen. Da vi naste morgen kom ind i stuen, var der tegnet hagekors på lysedugen, og gardinet var flænget. Vi håbede, at de rejste $\mathrm{i}$ dagens løb, det gjorde de nu ikke. Hele tiden søgte de strid, og englænderne, som vi havde stolet på, lod slet intet høre fra sig. De havde vist ikke rigtig forstået, at der var danske hernede, og at gården var dansk, så det lagde de ikke større vægt på.

I vandbeholderen, som kreaturerne drak af, vaskede alle disse »banditter" sig med sæbe. Far gav dem vandfade og spande, som de kunne bruge og forklarede dem, at kreaturerne ikke kunne drikke vandet, når der var sæbe i. Men da havde far sagt nok, løjtnanten skældte ham ud med de værste skældsord, der fandtes, fordi vi var danskere. Han opfordrede 
endda far til slagsmål, og da han straks var rede til det, betæenkte løjtnanten sig. Nu skulle min bror holde for, han blev kaldt "Landesverräter«, hans flag blev revet fra brystet, knækket, og en fod sat derpå. Løjtnanten betonede: »Noch sind wir die Preussen, noch haben wir das Recht«.

En lykke for os var, at min bror holdt sig rolig og holdt far tilbage, han var så ophidset og vred, at han ikke tog hensyn til noget. Vi stod også over for stor overmagt. Da min bror lige var kommet ind i huset, kom der en underofficer ind og arresterede ham. Det havde han fảet ordre til. Det nyttede ikke, vi forklarede, at han stod under Røde Kors og slet ikke havde med dem at gøre, med skulle han. Vi vidste godt, deres mening var at slæbe ham ud $\mathrm{i}$ skoven og så måske skyde ham. Det var nogle forfardelige minutter, som fulgte efter. Far var parat til at skyde, men Mor forhindrede ham deri. Nu gjaldt det om at slippe fra dem, vi var klar over, at en nat til kunne vi ikke risikere at være $i$ huset. Vi fandt på at flytte kreaturerne til en anden mark, som ligger 3-4 kilometer fra huset. Vi kunne ikke igen komme tilbage, vort eneste tilflugtssted var hos Lindstrøms, her overnattede vi alle. Nu kom vi igen i forbindelse med englænderne gennem vores fanger og et par hollandske fanger. Der var ikke noget, de hellere ville.

Englænderne lovede at komme om eftermiddagen $\mathrm{kl}$. 4 med et par pansere. Ventetiden blev lang. Hjemme gik køerne og blev ikke malket, og hestene stod i stalden, og huset var fuldt af »banditter«. Soldaterne var vist ikke så glade for, at vi ikke kom igen, og det var borgmesteren heller ikke. De anede nok uråd.

K1. 4 om eftermiddagen stillede to pansere hos borgmesteren, han var den første, der fik en lussing. Nu kørte de ned til os. Panserne var fyldt med alle de udenlandske fanger, som kunne være med.

Nede ved gården stod der to politibetjente. Den ene var så uheldig at hilse med »Heil Hitler« og blev straffet med en god lussing. (De engelske soldater opfattede naturligvis anvendelse af Hitler-hilsenen som en bevidst provokation). De fleste soldater var taget af sted, et par stykker var kun tilbage, de blev nøje udforsket. Og englanderne bestemte nu, at i fremtiden behøvede vi ikke indkvartering, hverken af soldater eller flygtninge, fordi vi var danske. Glade var vi, da vi om aftenen kunne tage hjem. Rundt omkring huset var der et farligt rod, der fløj med halm og forskelligt andet. Hist og her fandt vi også våben. Det var tydeligt at se, at de var taget af sted over hals og hoved.

Disse få dage var noget af det skrækkeligste, vi har oplevet under hele krigen. $\mathrm{Nu}$ har vi fået ro og fred og håber aldrig mere at komme ud for noget lignende.«

Sådan sluttede Tinnes beretning fra maj 1945. Mange år senere fortalte hun om historiens efterspil. Da SS-soldaterne forsvandt, lovede de at komme igen med hævn. Flere nætter efter, at de var forsvundet $i$ skoven, ventede Jens Hansen og Andreas Hansen med skudklare våben på, at de skulle komme tilbage til gården. ${ }^{118}$ 
Tinne, der skrev sin fristil på Rødding højskole, måtte i øvrigt blive nord for grænsen længere end beregnet. Grænsen var kun åben en kort tid, inden den atter blev lukket og bevogtet strengt af britiske tropper. Disse havde ikke nogen forståelse for ulovlig grænseovergang, og da Tinne var kommet over med en frihedskæmper uden pas, måtte hun pænt blive til 1949, inden hun kunne komme hjem igen. Helt lukket var grænsen dog ikke. Det tyske grænsemandskab kunne bestikkes, det danske lukke øjnene eller hjælpe, og stedkendte kunne med forsigtighed snige sig over. Blev de taget, kostede det frihedsstraf.

„Den 15. maj tog jeg så imod de kendte Tønderborgere Frida og Morten Bredsdorff, Ingeborg Jakobsen, Helene Moltke, Inger Enemark, J. N. Jefsen og Thorvald Petersen samt Kaptajn Lund fra Den danske Brigade. Vi mødtes på cementvejen, der går lige syd for grænsen, og fordelte så flæsk, ost, smør, kartofler og andre rare sager mellem tillidsmænd og skoler fra Aventoft til Jaruplund, - noget som alt var samlet i Nordslesvig og var begyndelsen til den storstilede hjælp, der $\mathrm{j}$ de svære år efter 1945 ydedes til Sydslesvig.

$\mathrm{Nu}$ fulgte en forvirret tid, hvor alle slags folk søgte Kirkevang - de fleste for at opnå noget.

Der kom englændere, danske frihedskæmpere og gardere, som bevogtede græensen. Der kom mere eller mindre fordagtige folk, der havde arbejdet i Tyskland og nu søgte at komme hjem til de hjemlige kødgryder. (Nogle af disse begyndte allerede at sive hjem over grænsen $\mathrm{i}$ de sidste krigsmåneder.) Der kom en yngre grevinde, der sagde, at hun var $i$ familie med en af Danmarks fornemste adelsslægter, sammen med moderen, som kun var baronesse. De sluttede op om vore sammenkomster efter at have indlogeret sig hos en dansk husmandsfamilie.

Storfolk, som ikke tidligere havde regnet os, var nu på hat og meget fidele. En søndag morgen stillede sådanne tre herrer og bad om »foretræde« hos mig.

"Ja, nu skal jeg kalde på min mand, “ sagde min kone, whan er ude i haven at fodre geden. « Jeg kom så ind, og de fremførte deres ærinde, som var, at de besøgte beskyttelse hos mig mod de russiske fanger, der endnu var på egnen, og de havde svært ved at forstå, at den måtte de søge andre steder.

Der stillede et par hjemvendte tyske flyverofficerer og bad mig om hjælp til at komme ind ved det danske flyvevåben, som bestemt manglede instruktører. Jeg sagde, at det havde jeg ingen indflydelse på, hvad de ikke kunne tro. Jeg anbefalede dem så at tage til Sydamerika. De blev imidlertid ved med at plage mig, hvorfor jeg sagde til dem, at de med deres koner skulle gå ud at tage kartofler op. Det havde Tyskland brug for. Vi i Danmark skulle nok få fløjet, hvad vi skulle, uden deres hjælp. Så gik de. "119

Kontaktmulighederne til slægt, venner og bekendte var blevet stærkt 
indsnævrede i de sidste krigsår, og bortset fra de første befrielsesmåneder indførtes der både fra dansk og britisk side stram kontrol og militærbevogtning af grænsen, så kun stedkendte kunne passere grænsen. Det gjorde mine forældre da lejlighedsvis også, når det var nødvendigt; men det kostede fængsel for dem, der blev taget.

$\mathrm{Nu}$ blev det gradvis muligt at udvide kontaktfladerne nordpå, selv om post- og trafikforhold $\mathrm{i}$ lang tid var dårlige. Trods vanskelighederne havde forbindelsen til familien Lund og Rødding højskole været holdt i gang under hele krigen. Familie og venner i Danmark havde også hjulpet med til at supplere rationerne op. De var især i de sidste krigsår blevet meget små. De mange praktiske hindringer og nu meget travle tider gav imidlertid kun lejlighed til sporadisk brevveksling. På Rødding højskole havde man selv haft nok at se til i de sidste krigsmåneder. Fra 1943 blev det meste af højskolen efterhånden beslaglagt til tysk indkvartering, og der kom en vrimmel af soldater og flygtninge.

Kort før kapitulationen hentede Gestapo Hans Lunds svigersøn, Johs. Rosendahl, der sad på Staldgården i Kolding, da befrielsen kom. ${ }^{120}$ Her er et glimt af et brev til Hans Lund først $i$ juni 1945, da alle havde nået at sunde sig lidt. Det hed bl.a. ")... Vi har haft meget lidt forbindelse over grænsen siden 5. maj. Vi er glade, at De stadig tænker på os, for rationerne er små, og vort gode lager gik der slemt svind $\mathrm{i}$, før vore hollændere (fangerne) for 10 dage siden kom hjem. Men vi var glade, at vi kunne gøre det; vore flygtninge og soldater fik jeg meget hurtigt ud efter kapitulationen.

De ubehagelige Blitzmädels fik lov at sætte de flag op igen, som de havde revet ned ... (da de raserede Kirkevangs sal) ... ellers er vi langsomt ved at forstå, at der ikke mere er noget Gestapo ... « ${ }^{121}$

\section{De sorte grises tid. »Im Jahre Null« - 1945}

Den tyske katastrofe åbnede muligheder for mange udviklingstendenser $\mathrm{i}$ det besatte og besejrede Tyskland såvel som det øvrige Europa. I de første efterkrigsår syntes alternativer at eksistere, og de ideologiske fronter var endnu ikke stivnede.

Det spæde danske mindretal havde 1920-45 haft megen modgang. Krigen havde også kostet dyrt i faldne, sårede og savnede. Til resterne af dette mindretal, der begyndte at rejse hovedet efter befrielsen fra nazismen, kom en eksplosivt voksende danskorienteret bevægelse. Det tyske sammenbrud blev således optakten til en skarp dansk-tysk kon- 
frontation i grænselandet. Der var mange elementer og mange nuancer i dette meget sammensatte fænomen, der blev til en dansk-sydslesvigsk løsrivelsesbevægelse. For tyskerne i Sydslesvig og Holsten blev den anledning til et hurtigt tilbagefald til den traditionelle tyske nationalisme. I tyske kredse opfattede man tidligt den stærke nyorientering mod Danmark som en flugt og en protest mod nød og flygtningemasser.

Det var britiske tropper, der havde befriet Nordtyskland. De stillede sig i de første besættelsesmåneder venligt over for det danske mindretals særønsker. Men Storbritannien havde ikke ført krig for at hjælpe Danmark og det danske mindretal. Briterne var gået $\mathrm{i}$ krig for at slå nazismen, for at få kontrolleret Tyskland militært og politisk, så tyskerne kunne blive genopdraget, og et nyt internationalt sikkerhedssystem kunne blive oprettet. Målet var i første række at administrere det besatte Tyskland sammen med de øvrige allierede besættelsesmagter. ${ }^{122}$ I den officielle britiske tankegang var der ikke plads til megen sympati for nationale mindretal. Det var der heller ikke hos de andre allierede. Tredivernes udvikling havde svakket tilliden til traktater og mindretalsordninger. Klare grænselandsløsninger måtte foretrækkes, hvor nationalitetsbrydninger blussede for stærkt op. ${ }^{123}$

Hovedproblemet for Storbritannien efter 1945 var den økonomiske svækkelse, man havde oplevet under de udmarvende krigsår. Afviklingen af det britiske verdensrige var en træg proces, men havde sin pris. Britiske politikere og britisk militær havde stadig nok at gøre. Tysklandsproblemerne og den britiske besættelseszone fik i perioden 1945-47 langtfra den opmærksomhed, de efter deres størrelsesorden kunne have fortjent.

For de britiske besættelsesstyrker var de første efterkrigsmåneder en vanskelig udfordring. Veje, broer og jernbaner skulle repareres. Sikkerhedszoner for millioner af krigsfanger måtte etableres, der var således meget store fangeområder $\mathrm{i}$ Sydslesvig og Holsten i efteråret 1945. Tusinder af stornazister og krigsforbrydere skulle arresteres. Den begyndende afnazificering gav anledning til betydelig usikkerhed og store personaleændringer i den offentlige sektor. Især i de første besættelsesår foregik en meget omfattende overvågningsaktivitet, politisk og sikkerhedsmæssigt, hvilket kunne være til betydelig irritation, da de britiske sikkerhedsfolk ikke altid var lige elegante eller nuancerede $i$ deres bedømmelse af situationen. Militæret frygtede i hvert fald indtil 1946 underjordisk nazistisk »varulvemodstand «, guerillaaktivitet, og det, man har kaldt »ruinkriminalitet«, florerede. Nød og lovløshed førte allerede $\mathrm{i}$ efteråret til, at det reorganiserede tyske ordenspoliti 
også blev genbevæbnet, $\mathrm{i}$ første omgang med træknipler. Det var svært at forsvare kul og levnedsmiddeldepoter med de bare næver. ${ }^{124}$

Næsten to millioner »displaced persons « fra 40 forskellige nationer skulle hjemsendes. Det var fra østeuropæiske krigsfanger og russere $i$ tysk uniform, slavearbejdere til jødiske koncentrationslejrfanger. 1000 kalorier pr. næse var taksten for tyske civile. Losladte fanger fik 1850 kalorier om dagen. Opgør mellem bander af »displaced persons« og sporadisk varulvevirksomhed forte til streng militærjustits. Der blev fældet omkring 200 dødsdomme i den britiske zone i de første tolv måneder. Halvdelen blev eksekveret.

Militæradministrationen slap hæderligt fra den første besættelsesperiode, men allerede fra 1946 bredte skuffelsen og resignationen sig. Hovedproblemet for briterne var: Hvordan kunne man holde Tyskland nede uden at lide økonomisk skade. Et delt eller helt opsplittet Tyskland ville være mest uskadeligt. Men økonomisk var en sådan udvikling ikke hensigtsmæssig. Vesteuropas udvikling var afhængig af en sund tysk økonomi. Bragte man ikke den britiske zones industri på fode, skulle man betale zonens import, og besættelsen blev noget af en økonomisk katastrofe for Storbritannien. De hårde vintre 1945-46 og 1946-47 betød store ofre for briterne. De måtte selv genindføre rationering af brød for at afhjælpe den værste nød $\mathrm{i}$ den britiske zone. ${ }^{125}$

Som efter første verdenskrig var Sydslesvigs og Holstens landbrug slidt ned, der manglede maskiner, drivmidler og kunstgødning og heste. Den animalske produktion måtte nødvendigvis $\mathrm{i}$ en sådan situation være beskeden.

Da hungersnøden begyndte vinteren 1945-46, var taksten to skiver brød pr. næse. Der var ingen kartofler, næsten ikke kød eller fedt. Roer og fiskefars af ubestemmelig karakter udgjorde grundstammen i føden.

Pr. uge fik man i februar 1947 2750-3300 gram brød, 100 gram kød, 350-500 gram andre fødevarer samt 50-100 gram fedt. De landmænd, der havde noget at handle med, kunne gøre gode forretninger på sortbørsbasis, ikke mindst med byboer. Intet under, at de sorte grises tid også prægedes af kriminalitet og prostitution. Allierede besættelsessoldaters cigaretter og mad trak uundgåeligt som en magnet. Den danske fødevarehjælp både til Sydslesvig og Holsten var et ekstra bidrag til den splittede og forhutlede befolkning. Det tog mange år at overvinde eftervirkningerne fra de først efterkrigsår. Elektrisk strøm eller gas var der heller ikke meget af. Der var næsten intet brændsel, så det gik hårdt ud over skove, krat og tørvemoser. ${ }^{126}$ 
Der var talrige tilpasningsproblemer for de mange forskellige befolkningsgrupper. Der var spændningen mellem hjemmehørende, tyske og danske og flygtningene. Britiske soldater måtte undertiden tvangsindkvartere dem med våben $i$ hånd. De mange tusind fanger, deporterede og »displaced persons«, der ofte havde lidt hårdt under naziregimet, gav svære problemer for civilbefolkning og besættelsesmagt. Det var ikke mindst polakker og russere, der hævnede sig grundigt. En del organiserede sig i regulære bander. Poul Kürstein har i Treklangen givet en farverig skildring af russiske krigsfanger i Flensborg, der fejrede befrielsesmånederne med torpedosprit samt andet mere eller mindre drikkeligt. ${ }^{127}$ Besættelsesmagten måtte efterhånden skride til drastiske metoder for at styre de mange tusind »displaced persons«. For de værste drab og udskejelser betød det dødsstraf, og der kom udgangsforbud og pigtråd for deres lejre. Briterne sørgede for, at de mange tusind internerede, der var blevet brutaliseret af lang tids fangenskab, blev hjemsendt hurtigt. Der var også mange russere, der havde været $\mathrm{i}$ tysk tjeneste, frivilligt eller tvunget. Trods episoder, bl.a. i Flensborg, blev de alle sendt hjem. Af russerne led både mange overløbere såvel som krigsfanger og deporterede en grum skæbne. ${ }^{128}$

De hjemvendende krigsdeltagere havde vanskeligt ved at finde sig til rette. De små landsogne blev overvaldet af flygtninge. Arbejdsløsheden var overalt voldsom, mange soldater fra byerne søgte til bønderne blot for at sikre sig et eksistensminimum. ${ }^{129}$

I løbet af 1946 fordampede britisk handlefrihed, den britiske zone blev sluttet sammen med den amerikanske, og i løbet af det næste år blev amerikanske synspunkter dominerende i Tysklandspolitikken. Fra begyndelsen af 1948 gik det stærkt henimod en cementering af den tyske deling og oprettelsen af den vesttyske forbundsrepublik, og efter valutareformen begyndte den økonomiske stabiliseringsproces så småt. ${ }^{130}$

\section{Lejren i Ladelund efter 1945}

Lejren i Ladelund fungerede kun i kort tid som KZ-filial. Efter grundig rensning blev lejren fra juni 1945 til januar 1946 brugt til efterbehandlingslazaret for amputerede tyske soldater. Egentlig var det meningen, at lejren derefter skulle rives ned og stilles op et andet sted, men så besluttede de britiske besættelsesmyndigheder, at den skulle anvendes til flygtninge.

Allerede i de sidste krigsmåneder var strømmen af flygtninge øst fra 
taget til. Med fordrivelsen af millioner af tyskere fra østområderne, fra Polen, i vinteren 1945-46, måtte Slesvig Holsten tage imod en meget betydelig del af flygtningemasserne.

Det betød en umådelig menneskelig, social og økonomisk-politisk belastning, selv om det slesvig-holstenske område bortset fra de største byer var sluppet fra krigens hærgen. 80.000 boliger var helt eller delvist ødelagt, 70.000 krigsinvalider skulle der skaffes lazaretplads til. Et par tal illustrerer befolkningsudviklingen. 57.000 flygtninge var strømmet til som følge af bombekrigens virkninger, bl.a. på Hamborg. Folketallet $\mathrm{i}$ den daværende slesvig-holstenske provins voksede fra $1.580 .000 \mathrm{i}$ 1939 til 2.669.000 i 1949. For Flensborg som for andre byer og landdistrikter i Sydslesvig og Holsten blev det tyske sammenbrud i maj 1945 således en katastrofe, der kastede både den hjemmehørende befolkning og de usselt stillede flygtningemasser ud $\mathrm{i}$ den dybeste materielle nød. Flensborg alene fik en befolkningstilvækst fra 67.000 til 110.000 . I adskillige slesvig-holstenske kommuner kom østflygtningene $\mathrm{i}$ flertal.

Overbefolkningen forte til katastrofale boligforhold. Hver kvadratmeter blev brugt. Kaserner, militære anlæg, lagre, baraklejre, alt blev fordelt til indkvarteringen af flygtningene. Hele familier måtte nøjes med et enkelt værelse. Det gav naturligvis ondt blod mellem hjemmehørende og flygtninge, nederlagets folkefællesskab var meget anstrengt. De hjemmehørende danske og tyskes opfattelse af de besværlige østflygtninge kunne grænse til racisme - »die Pilsudskis und Kaczmareks ...«. Flygtningene udgjorde en trussel mod dansk og tysk kultur, en tysk historiker har betegnet situationen med flygtningen som "... die preussische Überfremdung $\kappa^{131}$

De tyske skoler kunne slet ikke tage ordentligt mod de mange tusind flygtningebørn. Mange lærere var faldet eller i fangenskab. I $1947 \mathrm{var}$ klassekvotienten 87, i 1949 lå den stadig på 59. Arbejdsløsheden lå i mange år usædvanlig højt, det lå tungt med at skaffe nye arbejdspladser og med at overføre flygtninge til andre vesttyske områder med bedre beskæftigelse. De dele af det slagne Tyskland, der ikke var blevet oversvømmet af østflygtninge, søgte kun i meget begrænset omfang at aflaste flygtningeområderne. Den britiske besættelsesmagt havde med hård hånd tvangsindkvarteret flygtningene. Alligevel varede det meget længe, inden østflygtningene kom til at bo nogenlunde hæderligt. I 1949 var der 183.000 mennesker i flygtningelejre og nødboliger, det skønnedes, at ca. 450.000 boede under uværdige forhold. Endnu omkring 1956 var der 70.000 personer i slesvig-holstenske flygtningelejre. ${ }^{132}$ 
Heinrich Eichhorn, der var tysk lærer i Ladelund, har beskrevet forholdene i den lokale flygtningelejr. Den havde i april 1946 en belægning på 220 personer, i oktober 1946 var tallet dog faldet til 156.

De indkvarterede flygtninge fik $\mathrm{i}$ begyndelsen ikke mere end 2-4 kvadratmeter pro persona. Varme var der ikke meget af, fordi ovnene var blevet afmonteret. Mad måtte man lave på et fælleskøkken, og rationerne var meget små, kål-, kartoffel- og roesuppe var hyppigt på spisekortet. Kød, fedt og kaffe sås næsten ikke. Sult og kulde prægede store dele af befolkningens liv i de første efterkrigsår, men elendigheden var næppe mindre i en række af de lande, der var blevet hærget af nazisterne.

I de store flygtningelejre blev flygtningebørnene undervist adskilt fra de hjemmehørende børn. I Ladelund søgte man gennemgående at integrere flygtningebørnene og underviste kun undtagelsesvis i lejren. De sociale og sundhedsmæssige forhold var især $\mathrm{i}$ begyndelsen meget kritiske. I lejren var det ofte alles kamp mod alle, intet under, at flygtningebørn blev anset for at være mere frække end andre børn.

Det var i de forste mange år umuligt at skaffe arbejde nok til de mange flygtninge, især var det vanskeligt at skaffe passende arbejde til tidligere embedsmænd og til landmænd. Selv om der efterhånden blev gjort meget for at indpasse flygtningene i erhvervslivet, kunne det ikke undgås, at mange tusinder blev varigt socialt deklasserede. Gradvist lykkedes det dog at få lejren tyndet ud, familier og enkeltpersoner flyttede til andre slesvig-holstenske egne eller længere syd på til de store industriregioner. Først den 30. juni 1959 blev flygtningelejren i Ladelund endeligt opløst, og i dag er sporene af den tidligere arbejdslejr, koncentrationslejr og flygtningelejr slettet.

Hvordan oplevede flygtningene selv den usikre situation og de oftest trøstesløse og trange kår? Deres talsmænd i organisationer og politiske partier har givet udtryk for deres politisk-økonomiske synspunkter i massemedierne og i politiske forsamlinger. Hist og her har vi også litterære bidrag fra enkeltpersoner, der fortæller om deres egne personlige oplevelser som flygtninge. Karin Wolfgramm skrev som 16-årig en stil om sine oplevelser, mens hun var i lejren i Ladelund.

Karin Wolfgramm var fra Pommern. Sin far mistede hun i 1945, da han blev bortført af polske soldater. Resten af familien, hendes mor og mindre søskende, blev deporteret sidst i februar 1946. De blev sat på gaden fra deres landejendom med et kvarters varsel, kørt til en landsbykirke, hvor de sammen med talrige andre fordrevne i 3 uger sov på kirkegulvet. Russere og polakker udskrev dagligt fordrevne til 
arbejde. Den 25. marts 1946 nåede familien til Lübeck. Her blev de registreret og forplejet af den britiske besættelsesmagt, derefter blev de sammen med talrige andre ostflygtninge sendt til karantænelejren $i$ Klangsbøl i det nordvestlige Sydslesvig. Her begyndte deportationen fra Pommern for alvor at virke med fuld styrke, den materielle nød var stor, og i karantænelejren følte flygtningene, at de nærmest blev behandlet som straffefanger. De internerede flygtninge havde udgangsforbud dag og nat, levnedsmiddelrationen var to tynde skiver brød om dagen, dertil kom tynd roesuppe uden megen saft og kraft. Alle sultede, værst led børn og gamle. På en mark i nærheden af lejren såede en bonde sin mark til med hestebønner. Dårligt havde han tilsået marken, inden de forsultne flygtningen havde ribbet marken for hestebønner. Om natten stjal flygtningene roer. Det hændte også, at de slagtede et marskfår på forlandet, nøden gjorde dem til tyve og røvere, skriver Karin Wolfgramm.

Efter tre uger i Klangsbøl blev flygtningene stuvet sammen i lastvogne og kørte ad de elendige veje til den dystre, ugæstfrie lejr i Ladelund. Kun de voksne fattede elendigheden i dens fulde omfang.

Indkvarteringen foregik under meget primitive betingelser. Et ildsted, hvor man kunne riste de kartofler, man havde fäet eller tigget, blev oprettet i den pansergrav, KZ-fangerne i sin tid havde gravet. Den første vinter i Ladelund frøs alle meget, det var en meget kold vinter, og der var mangel på træ og andet brændsel. Det føltes ydmygende for de tidligere landmandsfamilier, at de nu måtte tigge kartofler hos standsfæller. Gryder til at koge dem i havde man ikke, kun blikdåser. Vandforsyningen var $\mathrm{i}$ begyndelsen også improviseret, den kom fra branddamme. Senere, i 1947, gravede flygtningene en brønd, der gav brunligt mosevand. Der var imidlertid ikke vand nok, så det måtte rationeres. Først flere år senere blev der gennemført en brøndboring, der gav godt rent vand.

De flygtninge, der var heldige, fik arbejde hos de lokale bønder. De levede ikke så dårligt, i hvert fald var det at få lov til at spise med hos de hjemmehørende landmænd den rene luksus for flygtningene. Men der manglede $\mathrm{i}$ uhyggelig grad flere arbejdspladser.

Der var dengang betydelige hedestrækninger ved Ladelund, og lyng var hovedbrændslet hos flygtningene i lejren. Tillige stillede kommunen et stykke tørvemose til rådighed for lejrbeboerne, så de selv kunne producere tørv.

Kun meget langsomt forbedredes flygtningenes kår i lejren. Kirkelige organisationer og andre hjælpeorganisationer bidrog til at sikre en 
bedre materiel standard. Som mange andre lejre blev flygtningelejren i Ladelund udtyndet, mange familier fik mulighed for at flytte; men kampen for at kunne forlade den trøstesløse baraktilværelse var hård, det tog lang tid at afvikle baraklejrene og at genhuse deres proletariat, og de hjemmehørendes praktiske solidaritet var begrænset. Karin Wolfgramm slutter sin fristil om flygtningetilværelsen i Ladelund således: "So sind wir nach langen Jahren der Entbehrung und der Not doch wieder einigermassen zurechtgekommen, aber wir dürfen nur nicht daran denken, was hätte sein können, wenn der verfluchte Krieg nicht über uns gekommen wäre und uns unsere Heimat erhalten geblieben wäre.« ${ }^{133}$

Som antydet var de første mange efterkrigsår særdeles begivenhedsrige. En episode, der huskedes, var det korte mellemspil, da min far startede skolen i Ellund i 1946. Det var i sig selv såre besværligt at starte en barakskole langt fra Ladelund, og både tyske myndigheder og tyske grupper og foreninger bekæmpede nye skoleoprettelser med både pæne og især mindre pæne metoder. I Ellund opleved han grove demonstrationer med støvletramp og det hele, der mindede ham betænkeligt om tiden 1933-45. Organisator var den senere så kendte tyske CDU-politiker Kai-Uwe von Hassel. Det skal tilføjes, at det tyske politi heller ikke altid syntes, at de danskorienterede sydslesvigeres kampformer var lige klædelige. Fra britisk side fulgtes udviklingen på begge sider nøje. Dansk og sydslesvigsk nationalromantik og drømmen om en genforening blev taget med et gran salt og dæmpet ned. Fra efteråret 1948 var budskabet klart, at Sydslesvig ikke ville komme tilbage til Danmark eller blive en selvstyrende region. ${ }^{134}$

Opgøret med nazismen kom min far hovedkuls ind $\mathrm{i}$, da han som sparsomt engelskkyndig lige efter befrielsen fungerede som tolk for britiske soldater, der internerede nazister. Soldaterne opførte sig stort set pænt, men tog alt, hvad der var af souvenirs, nazidolke osv. Blev der skjult noget, plyndrede de. Blandt de arresterede var en tysk læge, der havde nægtet at behandle en meget syg polsk fange, der havde været indkvarteret i Kirkevang. Den nazistiske læge fik et mindre komfortabelt ophold i britisk interneringslejr. Det siger sig selv, at de lokale nazister ikke var særlig begejstrede for det forestående opgør med fortiden og nazismen, der da heller ikke hverken af briterne eller siden af tyskerne blev gennemført særlig energisk og konsekvent; men min far bar de nu ikke nag til, formentlig bl.a. fordi han kendte dem så godt, at han skelnede mellem store og små nazister, det var ikke altid et spørgsmål om partibog. 


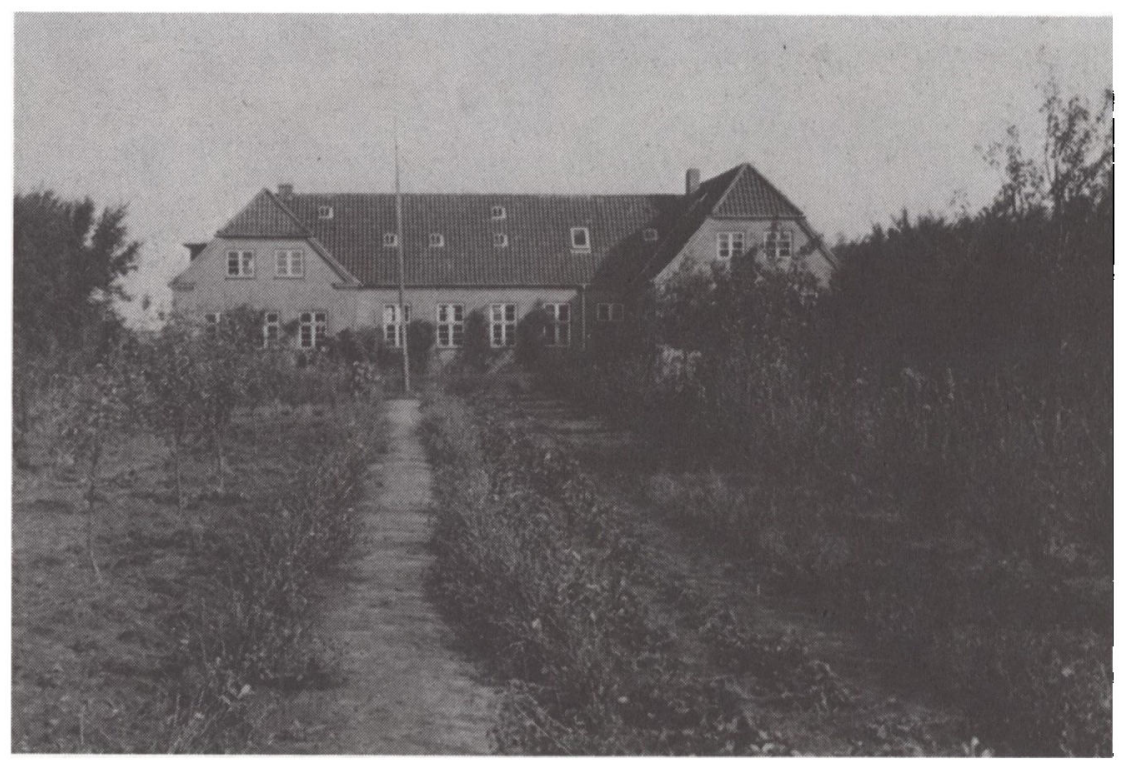

Kirkevang efter krigen, med den tilbyggede elevfloj til ungdomsskolen fra 1952. Dette billede er forlangst blevet historie, sådan som omgivelserne hastigt har forandret sig; men forsamlingshuset står og fungerer endnu. (Privateje)

Den umiddelbare efterkrigstid var også karakteriseret af kølig beregning og opportunisme, når det drejede sig om national orientering. Den lokale tyske præst havde indtil sent på krigen, som store dele af befolkningen, været nazist. For en kort stund efter 1945 blev han som mange andre tyske holder af Flensborg Avis og fortsatte i øvrigt derefter sin traditionelle tysk-nationale linje. Klasseskel, aggressiv nationalisme og politisk intolerance karakteriserede også efterkrigstidens Sydslesvig og Holsten. Først langsomt trængte demokratiske spilleregler ind. For min far var det især et problem, at vesttyskerne så tidligt fik lov at bære våben, og at gamle, og svært kompromitterende, nazister så let fik pladser $i$ solen.

Han interesserede sig til det sidste levende for udviklingen syd for grænsen, også for tysk politik og kultur, men kun for det demokratiske Tyskland.

Den lokale situation gav heller ikke nogen anledning til at fravige den stærke skepsis, det illustreres i et brev til Hans Lund den 16. november 1956 efter den ungarske opstand: "... Vi er nogle i Sydslesvig, 
der er rystede over, at man ingen medfølelse møder med ungarerne, kun had til Rusland, akkurat som da fangerne fra Neuengamme var her .... ${ }^{135}$

I en erindringsskitse skriver han følgende om skoleforholdene efter krigen:

"Når jeg i sommeren 1945 cyklede hen ad Ladelund gade, kunne det hænde, at en dreng råbte: "Lindstrøm, må æ komm' til skole ved dæ? "Ja, når du må for din far!« Eller det hændte, at en stor skolepige, jeg ikke havde kendt før, frejdigt kom hen og meldte sig i dansk skole.

Ellers var det mest forældrene, der kom. Og der var nogle, der påberåbte sig deres danskhed, skønt de til da havde skjult den godt.

Bedre syntes jeg om dem, som stilfærdigt kom og sagde: "Jeg er tysk opdraget, så jeg kan ikke være så dansk; men jeg vil have mine børn opdraget på dansk.«

Der kom også pæne flygtninge, der ville have deres børn i dansk skole. Dem måtte vi afvise. Som f.eks. konen fra Stettin, der nok mente, at hendes børn kunne blive optaget, da hendes mand havde sejlet på København.

Antallet af børn i skolen voksede i løbet af sommeren 1945 fra 11 til 48. Så måtte vi lukke for tilgangen, da vi ikke kunne rumme flere, selv om min kone holdt skole $\mathrm{i}$ vor ramponerede sal.

Men nu begyndte Ladelund danske skole at skyde knopper, idet folk i nabosognene arbejdede på at få stedlige danske skoler. Og efterhånden som de engelske myndigheder gav tilladelse til, at danske larere måtte komme ind $\mathrm{i}$ landet, oprettedes den ene skole efter den anden, tit under meget primitive forhold for både elever og lærer.

Der kan skrives et langt kapitel om, hvorledes de danske lærere og larerinder sad og frøs $i$ deres dårlige boliger $i$ den strenge vinter 1946-47. Men kun fá klagede sig.

Begejstringen var lige stor hos forældre som hos børn og hos de lærere og lærerinder, der $\mathrm{i}$ hast søgte at bygge en dansk skole op på ingenting. Og de, som nu sidder $\mathrm{i}$ gode bygninger $\mathrm{i}$ velordnede forhold, ville nok ikke undvære disse forste drøje år efter 1945. Og en hel lovsang kunne synges om de lærerkoner, der under de vanskeligste forhold holdt ud med mand og born.

Det kunne jo ikke gå hurtigt nok, og selv var jeg overmåde glad, hver gang jeg kunne ringe til daværende rektor Bernhard Hansen, at nu var der så og så mange børn i den by tilmeldt til den danske skole.

En af naboskolerne til Ladelund blev oprettet $i$ sovekammeret på en gård, hvor konen var den drivende kraft. Hun var blevet syg, men nu skulle det ske, og vi holdt møde hos hende en søndag eftermiddag.«

Den eksplosive udvikling i det danske organisationsliv forte til ekstra arbejdsopgaver. 
»... Skønt danske borgere i Sydslesvig ikke må blande sig i politik, ikke har valgret hverken i Danmark eller i Tyskland, måtte jeg lade princippet hvile en tid og hjælpe folk som eneste danske lærer i Syd-Tønder amt på det tidspunkt.

En af de største sydslesvigske foreninger blev oprettet en eftermiddag i baglokalet af en købmandsbutik, hvor vi sad på omvendte kasser og tønder, for - som en mand sagde til mig i slutningen af krigstiden: "Kan æ komm' i den danske minderhed? For nu er det tid! « Vedkommende havde jeg kendt $i$ mange år og vidst, at han havde stærke danske sympatier. Men forst nu vovede han og mange andre at tage skridtet og åbent bekende sig til danskheden.

Og gudstjenester og møder havde en tilslutning hernede som aldrig før eller siden. Vor første gudstjeneste $\mathrm{i}$ Kirkevang i maj 1945, som vi måtte holde $\mathrm{i}$ vore små stuer, sprængte rammerne.

Vi fik salen så nogenlunde i stand, så vi atter kunne samles der. Der var nogle hollandske fanger, som endnu ikke kunne komme hjem, os en god hjælp. Hollænderne er gode til at skure.

Og ved møder og gudstjenester var der trængsel. Nu kunne vi få danske talere i massevis. I den forste tid måtte de trakke i uniform, - engelske uniformer, der ikke altid passede lige godt. Efter den lange faste hungrede vi alle efter at være sammen med landsmænd og høre et godt ord. Desværre var det ikke altid lige værdifuldt, hvad vi fik fyldt på. Foruden de udmærkede folk, der virkelig havde noget at bringe landsmændene, var der også en del, på hvem det passede, hvad en kendt sydslesviger sagde: »De kender hverken Danmark eller Sydslesvig!«

Af uhyre værdi var det arbejde, der udførtes af danske læger og sygeplejersker. De har reddet mange børn og voksne i Sydslesvig. Ofte var det kun sæbe og brød, folk manglede. Det fik vi af Sydslesvig-hjælpen.« ${ }^{136}$

\section{Den første ungdomsskole i Ladelund efter 1945}

Det hedder i elevprotokollen november 1947, at Ladelund Sprogskole åbnede planmæssigt mandag den 3. november 1947. De 13 indmeldte elever var mødt. De blev budt velkommen og fik sengepladser anvist. Efter at ordensregler og timeplan var blevet gennemgået, sluttede dagen med aftensang. Skolens formål var i første omgang at lære unge tysktalende piger fra dansksindede hjem dansk og gøre dem mere fortrolige med danske forhold, inden de tog på skole eller fik plads i Danmark. Det havde været danske højskolemænd, der fandt, at der var behov for en sådan forberedelse, fordi der kom for mange nordpå efter 1945, der ikke kunne dansk og derfor fik for lidt ud af deres ophold. Dansk Skoleforening tog sagen op og fik sprogskolen placeret i forsamlingshuset. Med det danske skolevæsens udvikling ændredes elevernes forudsætninger sig gradvist, og sprogskolen blev til en ungdomsskole. Det 
blev $\mathrm{i}$ begyndelsen, indtil en tilbygning i 1952 kunne tages $\mathrm{i}$ brug, til skole under ret så primitive forhold. De fleste af de ret små elevhold var præget af små kår, af en tilværelse i et hærget samfund med bolignød. De var fattige, og de var sultne og kunne næsten blive ved med at spise i det uendelige. ${ }^{137}$ Min far skriver 3. december 1947: "Det er måske en tilfredsstillelse, at det er den første faste ungdomsskole $\mathrm{i}$ Sydslesvig siden Ågård. Det er vel ikke just det, Grundtvig har tænkt på, eller Blicher, og vel heller ikke Christen Kold. ... I det store mål, som er højskolens, mennesket først, så kristen opdragelse i danskhed. Vi håber, at de fleste vil styrkes $\mathrm{i}$ denne; men også, at én og anden vil opdage, at de er tyske. Hvis man tror, at ånden virker $\mathrm{i}$ frihed, gør det heller ikke noget ....1138

Det var ikke altid lige let, men $\mathrm{i}$ hvert fald sjældent kedeligt at drive skole $i$ et Sydslesvig præget af stærke spændinger og mærkbar forandring. Mine forældre forlod Ladelund i slutningen af 1961 for at flytte til Tønder. Kort tid efter skrev min far nogle korte erindringsskitser til Treklangen, og her er de afsluttende bemærkninger:

"Nu er alt dette historie. Her er ordnede forhold. Tallene er blevet mindre i vore skoler og foreninger, men livet også sundere. Dog stadig gælder det, at altid dukker nye problemer op i grænselandet. Der er vedblivende brug for forposter for dansk sprog og sind. Med det danske sprogs levedygtighed står og falder danskheden i Sydslesvig.

Engang omkring 1924 sagde Peter Lorenzen, Østerbymark, manden, der først gav husly til danskundervisning og senere til det første danske forsamlingshus i Syd-Tønder amt (Pærs Pissel), i en mismodig stund til mig: "Vi vær åltins minner.« Han blev selv tro til det sidste; men som dengang har også en del efter 1950 tabt modet ved tanken om at blive de få.

Mod denne tankegang kan det være godt at blive mindet om sprogmanden Madvigs mandige ord: "Fordi vi er færre, er vi ikke ringere. $\aleph^{139}$

\section{LITTERATUR}

Theo Christiansen: Schleswig 1836-1945. Eine Stadt und ihre Bürger in 110 Jahren des Wandels aller Lebensbedingungen (1976).

F. S. V. Donnison: Civil Affairs and Military Government in North-WestEurope 1944-46 (1961).

K.-D. Erdmann: Die Zeit der beiden Weltkriege. I Gebhardt: Handbuch der deutschen Geschichte (1976).

Knud Fanø, Inger Bjørn Svensson og Fr. Rudbeck: DUG Det unge Grænseværn (1983). 
Flensburg. Geschichte einer Grenzstadt (1966).

Bjarne W. Frederiksen: Danmarks Sydslesvigpolitik efter det tyske sammenbrud i 1945 (1971).

Richard Grunberger: A Social History of the Third Reich (1971).

Ole Harck: Jüdische Denkmäler in Schleswig-Holstein (1980).

Erich Hoffmann og Peter Wulf: "Wir bauen das Reich". Aufstieg und erste Herrschaftsjahre des Nationalsozialismus in Schleswig-Holstein (1983).Heri:

Wolfgang Kopitzsch: Politische Gewalttaten in Schleswig-Holstein in der Endphase der Republik. Side 19-40.

Lawrence D. Stokes: Der Fall Radke. Zum Tode eines nationalsozialistischen.

Jörn-Peter Leppien: "Das waren keine Menschen mehr ...« Aus der Chronik der Kirchengemeinde - Pastor Johannes Meyer über das Konzentrationslager Ladelund 1944. Grenzfriedenshefte 1983, s. 143-185.

Anders Ture Lindstrøm: Landet Slesvig-Holstens politiske historie i hovedtræk (1975).

Carsten R. Mogensen: Dansk i hagekorsets skygge. Det tredie rige og det danske mindretal i Sydslesvig 1933-39. I-III, licentiatafhandling. Udgivet i forkortet version 1981. Studieafdelingen ved Dansk Centralbibliotek, Flensborg.

John North: North West Europe 1944-45 (1977) The Achievement of 21st Army Group. H. F. Petersen: I krig og fred (1946).

Lorenz Rerup: Slesvig og Holsten efter 1830 (1982).

Rudolf Rietzler: "Kampf in der Nordmark « Das Aufkommen des Nationalsozialismus in Schleswig-Holstein (1919-1928) (1982).

Claus Scharff \& Hans-Jürgen Schröder: Die Deutschlandpolitik Grossbritanniens und die britische Zone 1945-49 (1979).

Th. Steltzer: Sechzig Jahre Zeitgenosse (1966).

Gustav Stolper: Deutsche Wirtschaft seit 1870 (1965).

Gerhard Stoltenberg: Politische Strömungen im schleswig-holsteinischen Landvolk 1918-1933 (1962).

Gerd Stolz: Die Geschichte der Polizei in Schleswig-Holstein (1978).

Timothy Alan Tilton: Nazism, democracy and the peasantry: Nazi success and neonazi failure in rural Schleswig-Holstein. (Duplikeret) Harvard University 1972 (forstudie til den nævnte bog) (findes på Landesbibliothek i Kiel).

Karl-Heinz Varain: Parteien und Verbände (1964).

Harald Voigt: Der Sylter Weg ins Dritte Reich. (1977).

D. C. Watt: Britain looks to Germany (1965).

\section{NOTER OG HENVISNINGER}

1. Min fars beretninger fortalt efter hukommelsen.

2. Dagbog 5. november 1918. Gustav Lindstrøms korte dagbogsnotitser 1917-18 er deponeret på Landsarkivet, Åbenrå.

3. Om den generelle uro se artiklen Samfundshjælpen i Erhvervshistorisk Årbog, 1978 s. 7-10, samt Bent Jensens disputats Danmark og det russiske spørgsmål 1917-24 (1978), side 143-58.

K. D. Erdmann s. 111-73, Rietzler s. 73-89, Stoltenberg s. 24-26.

Gerd Stolz: Die Polizei in Schleswig-Holstein s. 54-55.

4. Dagbog 17. november 1918. 
5. Højskolebladet 4. august 1922 s. 918-19.

6. Samme.

7. Samme s. 919 og s. 922.

8. Højskolebladet den 11. august 1922 s. 951.

9. Samme s. 953-56.

10. Lindstrøm fortæller om 40 år i Mellemslesvig. Treklangen april 1962 s. 3-4.

11. Gustav Lindstrøm, dagbog marts 1922.

12. Gustav Lindstrøm, dagbog juni 1922.

13. Gustav Lindstrøm, dagbog 17. juni 1922.

14. Treklangen april 1962 s. 4-5, maj 1962 s. 22-23.

15. Stoltenberg s. 9-18, Rudolf Rietzler s. 30-33, s. 25-28.

16. Rudolf Rietzler s. 60-63, s. 299-300.

17. Stoltenberg s. $24-28$.

18. Stoltenberg s. 49.

19. Stoltenberg s. 50-52.

20. Rietzler s. 318-24, Erdmann s. 287-296.

21. Erdmann s. $278-80$, Rietzler s. 60 , Stoltenberg s. 57 .

22. Gerd Stolz s. 104-5.

23. Stoltenberg s. 66-69.

24. Jvf. T. A. Tilton: Nazism, Neo-Nazism and the peasantry, Rietzler s. 18-19.

25. Rerup: Slesvig-Holsten $1830-1980$ s. 355-56, Rietzler s. 229.

26. Erdmann 278-80, G. Stolper: Deutsche Wirtschaft seit 1870 s. 99-105, s. 128-31.

27. Stoltenberg s. 107-112. K. L. Lorenzen-Schmidt i Wir bauen das Reich s. 276-77.

28. Rødding Højskoles årsskrift 1928 s. 97-102.

29. Stoltenberg s. 121-27.

30. Flensborg Avis januar 1929, se f.eks. også 15.3.1929.

31. Stoltenberg s. 129-41.

32. Rietzel s. 402-10, s. 424-32.

33. Stoltenberg s. 150, Voigt: Der Sylter Weg ins Dritte Reich s. 65 og 70.

34. Tilton s. 71-72.

35. Wolfgang Kopitzsch s. $20-21$, s. 24-36.

36. Samme s. 37.

37. Husumer Nachrichten 30. maj 1984 s. 2.

38. Erdmann s. 316-18, Der Spiegel 4. juni 1984 s. 144-66.

39. Stolz s. 130.

40. Stoltenberg s. 192.

41. Wir bauen das Reich s. 396-98, Kurt Jürgensen: Die Gleichschaltung der Provinzverwaltung.

42. Theodor Steltzer: Sechzig Jahre Zeitgenosse (1966) s. 108-9.

43. Stolz s. $130-47$.

44. Lawrence D. Stokes: »Meine kleine Stadt steht für tausend andere ...« Zur Geschichte Eutins vor und nach 1933. Mitteilungen der Gesellschaft für SchleswigHolsteinische Geschichte. Februar 1981.

45. Stolper s. 176-80.

46. Klaus-J. Lorenzen-Schmidt: Landwirtschaftspolitik und landwirtschaftliche Entwicklung in Schleswig-Holstein 1933-45 i "Wir bauen das Reich « s. 285-86, s. 289-93, s. 303-308. Klaus Groth: Der Aufbau des Adolf-Hitler-Koogs. Ein Beispiel nationalsozialistischer ländlichen Siedlungsbaus, Wir bauen das Reich s. 309-31. 
47. Citat fra manuskript til tale i To Lover (udateret, fra midt $i$ halvtredserne, privatarkiv).

48. H. D. Andresen i Flensborg Avis 17. april 1982.

49. Politimester Erik Bøving, Tønder, fortæller. Sprogforeningens Almanak $1980 \mathrm{~s}$. 89-93.

50. Årsskrift for Rødding Højskole 1930 s. 73.

50a H. F. Petersen s. 51.

50b Flensborg Avis 11. oktober, 19. oktober, 12.-13. november 1931. Flensborg Avis 21. oktober 1931. GL dagbog (udateret) november 1931.

50c Gustav Lindstrøm dagbog 3. marts og 19. april 1933.

50d GL Dagbog 19. og 21. marts 1932.

51. Arne Brandt Pedersen til Gustav Lindstrom 9. august 1933. GL privatarkiv.

52. Højskolebladet 28. september 1934 s. 532-33. Årsskrift for Rødding højskole 1934. Flensborg Avis 11. september 1934.

53. Ârsskrift for Rødding højskole 1934. Dagbog GL, udateret, august 1937, 19. januar 1938. Direktor Victor Vilner den 26. oktober 1956, tale. Bestyrelsesprotokol 9. januar 1936, To Lovers arkiv, Rigsarkivet.

54. Dagbog, udateret notits november 1933. Dagbog 11. januar 1934.

55. Jvf. f.eks. Chr. Stenz: Dansk lærer i grænselandet (1983), s. 82-83. Voigt s. 92-93, s. 96-98.

56. Dansk Skoleforenings årsberetning $1934-35 \mathrm{~s} .7$.

57. Nordschleswigsche Zeitung 11.-12. november 1934.

58. Hejmdal 5.-6. december 1934.

59. Dansk Skoleforenings årsberetning 1933-34 s. 22.

60. Samme s. 18.

61. Dansk Skoleforenings årsberetning 1934-35 s. 13-14.

62. Dansk Skoleforenings årsberetning 1935-36 s. 11.

63. Ref. Jydske Tidende 28 . februar 1936.

64. Jvf. radioudsendelsen Desertør (DR-arkiv) 1979. Antinazistisk agitation julen 1937: Franz A. Julius går $i$ en stærkt antitysk og antinazistisk artikel i »Julehilsen fra Rens efterskole« ind for mere støtte til Tønning skolen. Agiterer bl.a. for Det unge grænseværn. Franz A. Julius var elev vinteren 1933-34.

65. DUG, Det unge Grænseværn s. 13-31, s. 94-95.

66. GL dagbog 19. november 1936.

67. Jydske Tidende 3. marts 1936.

68. udateret, dagbog GL februar 1937.

69. Mogensen (dupl.) s. 449.

70. Dansk Skoleforenings årsberetning 1939-40 s. 26-34. Udateret GL dagbogsnotat nov.-december 1936. Mogensen (dupl.) s. $467 \mathrm{og}$ s. 481. Folkeskolen 7. januar 1937.

71. Dansk Skoleforenings årsberetning $1939-40$ s. 13-14.

72. Theo Christiansen s. 81-82, Flensburg. Geschichte einer Grenzstadt s. 447. KlüverBrandt s. 321 og 324.

73. GL i Treklangen august 1962 s. $62-63$.

74. H. F. Petersen s. 128.

75. Samme s. 128-29. Flensburg. Geschichte einer Grenzstadt s. 450.

76. Theo Christiansen s. 84.

77. Chr. Stenz 9. april-kronik i Jydske Tidende 1980. 
78. Svend Johannsen s. 89-90, 153-58, 198-239.

79. "Formålet med disse lejre (tyske arbejdslejre og kaserner red.) er jo at opdrage disse unge til gode nazister. Det er denne tvangsnazificering og tvangsfortyskning af vor ungdom vi har nedlagt protest imod.« (Sekretær Fr. Petersen i Haderslev 27. februar 1936). Jydske Tidende 28. februar 1936.

80. Grunenberg s. 191. "Der Kerl gehört gehängt«. Der Spiegel 1978 nr. 28 s. 36-49.

81. Treklangen august 1962 s. 63 (brev i privatarkiv).

82. Samme s. 63-64.

83. GL til Hans Lund 19. november 1942. Hans Lunds arkiv, LAA.

84. Treklangen september 1962 s. 78.

85. GL til Hans Lund 19. november 1942 (Hans Lunds arkiv).

86. Treklangen september 1962 side 78-79.

87. H. D. Andresen til GL 4. juni 1940, privatarkiv.

88. H. D. Andresen til GL 6. februar 1941.

89. H. D. Andresen til GL 6. april 1941.

90. H. D. Andresen til GL 21. marts 1941.

91. Theo Christiansen s. 86.

92. H. D. Andresen 24. juni 1942 til GL.

93. Jvf. bl.a. optagelsen Cykelpræst med Martin Nørgaard, DR-arkiv 1980-81, Flensborg Avis 22. august 1983 og 4.-5. marts 1979.

94. Fremtiden 1981/3 s. 30.

95. H. D. Andresen til GL 13. september 1942.

96. H. D. Andresen til GL 19. november 1942.

97. H. D. Andresen til GL 24. marts 1943.

98. H. F. Petersen s. 161.

99. Grunenberg s. 188-96.

100. Theo Christiansen s. 86-87.

101. Ole Harck: Jüdische Denkmäler in Schleswig-Holstein s. 1-10, 19-28.

102. H. D. Andresen til GL 12. august 1943.

103. H. D. Andresen til GL 9. februar 1944.

104. Fr. Dinsen Hansen til familien Lindstrøm 30. juli 1944.

105. Theo Christiansen s. 87-88, Erdmann s. 581-85.

106. Treklangen 1962 s. 117-18. H. Eichhorn i Jahrbuch für die Schleswigsche Geest 1961 s. 168-83. J. P. Leppien i Grenzfriedenshefte 1983.

107. Oplysninger til ATL april 1980, jvf. udsendelsen »Cykelprasten«.

108. H. D. Andresen til GL 10. december 1944.

109. Jvf. radioudsendelsen "Portræt af en ung mand « april 1979, med Karl Otto Meyer. Die Zeit 14. juli 1978, Die Zeit 9. juni 1978, Die Zeit 11. august 1978, Die Zeit 30. november 1979, Grunenberg s. 191-92.

110. H. D. Andresen til GL 10. december 1944.

111. H. D. Andresen til GL 26. januar 1945.

112. Treklangen oktober 1962 s. 92.

113. Samme s. 92.

114. John North: North-West Europe $1944-45$ (1977) s. 233-40.

115. Sprogforeningens Almanak 1980 s. 99-102.

116. Oplysninger fra Hedvig og H. D. Andresen, Agtrup.

117. Donnison s. 351-56, 386-88. 
118. "Tinne«s fristil fra Rødding højskole sommeren 1946, kopi, suppleret med mundtlige oplysninger.

119. Treklangen december 1962 s. $135-36$.

120. Skriftlig oplysning fra Richard Andersen, Askov, maj 1984.

121. GL til Hans Lund 3. juni 1945, Hans Lunds arkiv, Landsarkivet.

122. Se bl.a. Anders Ture Lindstrøm: "Danskernes militante nationalisme var Storbritanniens hovedproblem« i Fremtiden 1981/3 s. 29. Claus Scharf/Hans Jürgen Schröder: Die Deutschlandpolitik Grossbritanniens und die Britische Zone (1979).

D. C. Watt s. 15, Kurt Jürgensen s. 103-27.

123. Bjarne W. Frederiksen: Danmarks Sydslesvigpolitik efter det tyske sammenbrud i 1945 s. 18-28, 176-78. Political Division, Control Commission for Germany/ British Element til German Department, Foreign Office 26.1.1948 FO 371/70545/ 9294.

124. Steltzer s. 188-91, Stolz s. 301-13. Jochen Thies i Scharf/Schröder s. 36-38. Grænsevagten 1946 s. 151, s. 233, s. 273. Die Zeit 5.12.1946, interview med ministerpræsident Th. Steltzer.

125. D. C. Watt: Britain looks to Germany s. 54-59, 62-63.

126. Statistische Monatshefte 1966 (Kiel) s. 266-76, Stolz s. 456-57.

127. F. S. V. Donnison: Civil Affairs and Military Government in North-West Europe 1944-46 s. 351-56, s. 386-88. Nicolai Tolstoy: Victims of Yalta (1978) s. 341-43, 468-70.

128. Poul Kürstein: Russerne i Flensborg, Treklangen maj 1960 s. 19-22.

129. Carl Enewaldsen: Veränderung des Dorfes und der Feldmark Tinningstedt von 1937 bis 1958. Jahrbuch für die Schleswigsche Geest (1960) s. 171-72.

130. Erdmann s. 710-15, 743-55.

131. K. H. Varain: Parteien und Verbände (1964) s. 1-5. Flensburg, Geschichte einer Grenzstadt s. 458. Walter Damm s. 67-73.

132. Varain s. 1-11. Anders Ture Lindstrøm: Landet Slesvig-Holstens politiske historie s. 84-86. Walter Damm s. 147-52.

133. Karin Wolfgramm: Als Flüchtling im Lager Ladelund. Jahrbuch für die Schleswigsche Geest (1961) s. 177-83.

134. Fremtiden $1981 / 3$ s. $34-36$.

135. Gustav Lindstrøm til Hans Lund 16.11.1956. Hans Lunds arkiv.

136. Treklangen jul-nytår $1962-63$ s. $150-52$.

137. G. K. Brøndsted: Sydslesvig i dag (1955-56) s. 245-47.

138. Notat 3.12.1947. Gustav Lindstrøms privatarkiv.

139. Treklangen jul-nytår $1962-63$ s. 152 . 
